OECDpublishing

\title{
MISSION-ORIENTED INNOVATION POLICY IN JAPAN
}

CHALLENGES, OPPORTUNITIES AND FUTURE OPTIONS

OECD SCIENCE, TECHNOLOGY AND INDUSTRY POLICY PAPERS April 2021 No. 106 


\section{2 | MISSION-ORIENTED INNOVATION POLICY IN JAPAN}

This paper was approved and declassified by written procedure by the Committee for Scientific and Technological Policy (CSTP) on 5 March 2021 and prepared for publication by the OECD Secretariat.

Note to Delegations:

This document is also available on O.N.E. under the reference code:

DSTI/ STP(2021)1/FINAL

This document, as well as any data and any map included herein, are without prejudice to the status of or sovereignty over any territory, to the delimitation of international frontiers and boundaries and to the name of any territory, city or area

The statistical data for Israel are supplied by and under the responsibility of the relevant Israeli authorities. The use of such data by the OECD is without prejudice to the status of the Golan Heights, East Jerusalem and Israeli settlements in the West Bank under the terms of international law

Note by Turkey:

The information in this document with reference to "Cyprus" relates to the southern part of the Island. There is no single authority representing both Turkish and Greek Cypriot people on the Island. Turkey recognises the Turkish Republic of Northern Cyprus (TRNC). Until a lasting and equitable solution is found within the context of the United Nations, Turkey shall preserve its position concerning the "Cyprus issue".

Note by all the European Union Member States of the OECD and the European Union:

The Republic of Cyprus is recognised by all members of the United Nations with the exception of Turkey. The information in this document relates to the area under the effective control of the Government of the Republic of Cyprus.

COECD 2021

The use of this work, whether digital or print, is governed by the Terms and Conditions to be found at http://www.oecd.org/termsandconditions 


\title{
Challenges and opportunities of mission-oriented innovation policy in Japan
}

\author{
By Philippe Larrue \\ (OECD Directorate for Science, Technology and Innovation)
}

This report assesses the potential for mission-oriented innovation policies (MOIPs) to contribute to the sustainable transition in Japan, and examines the challenges and opportunities that MOIPs would present. As part of a series of MOIP national case studies, the report finds that the ongoing ambitious and top-down MOIPs led by the centre-ofgovernment build upon a long history of proactive and goal-oriented policy intervention. MOIPs in Japan are the latest step of decades of efforts to reduce the fragmentation and lack of holistic coordination of Japan's science, technology and innovation policy in order to proactively address societal challenges. Available evaluations of these policies demonstrate very encouraging results in that regards. The study concludes with recommendations to pursue these efforts, including by mainstreaming these policy initiatives across the government structure and complementing them with more bottom-up challenge-based initiatives.

Keywords: Science and technology, Innovation, societal challenges

JEL codes: O14, O25, O38, Q55 


\section{Acknowledgements}

This report has been prepared and drafted by Philippe Larrue, who is responsible within the OECD Secretariat for the project on the design and implementation of mission-oriented innovation policies to address societal challenges, conducted under the aegis of the OECD Committee for Scientific and Technological Policy (CSTP) during the biennium 20192020. The main results of the CSTP project are synthesised in the OECD Science Technology and Industry Policy Paper N ${ }^{\circ} 100$ (https://doi.org/10.1787/3f6c76a4-en).

We wish to acknowledge the contribution of Tateo Arimoto, Kazuhito Oyamada, Kazuhisa Yoshida and Yuki Yoshida, Center for Research and Development Strategy, Japan Science and Technology Agency (JST-CRDS, Japan). Their support was essential to undertake this case study.

We are also grateful to Mr. Takuro Yoshimoto from the Ministry of Education, Culture, Sports, Science and Technology (MEXT) and the Cabinet Office, and Prof. Yuko Harayama from Tohoku University and RIKEN.

The document benefited from a review by Alessandra Colecchia, head of the Scientific and Technology Policy (STP) division and by the Science, Technology and Industry Director's Office. Blandine Serve provided valuable statistical support and Bora Kim careful proofreading (both from the Science and Technology Policy division, OECD).

Many thanks also to Yoshiaki Tamura from the OECD Global Science Forum for his support to fieldwork and analysis.

Detailed information on the Cross-ministerial Strategic Innovation Promotion Program (SIP), the Moonshot Research and Development program ('Moonshot') and the Impulsing Paradigm Change through Disruptive Technologies program (ImPACT) are available on the MOIP Online Toolkit (https://stip.oecd.org/stip/moip), a comprehensive knowledge platform on mission-oriented innovation policies. The development of the MOIP Online Toolkit was funded by the European Union's Horizon 2020 research and innovation programme.

The case study benefited from the discussions held in a seminar jointly organized in Tokyo by the OECD Global Science Forum and the Japanese authorities on 4 December 2019.

Drafts of the case study report went through several rounds of fact-checking coordinated by Noriko Saito from MEXT and supported by Kazuhiro Sawada, Permanent Delegation of Japan to the OECD. The author would like to thank all those who provided comments and inputs during this process of validation.

Finally, the project has benefited from plenty of interactions with many policy makers, researchers and stakeholders during the on-site mission in Japan in December 2019. 


\section{Table of contents}

Challenges and opportunities of mission-oriented innovation policy in Japan .................................. 3

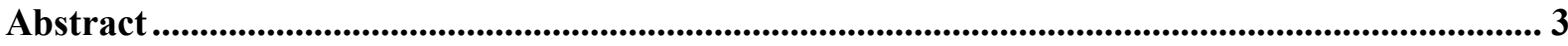

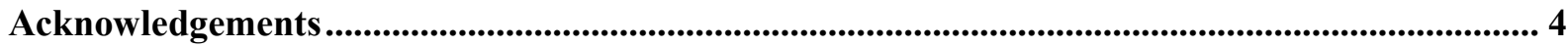

Executive summary

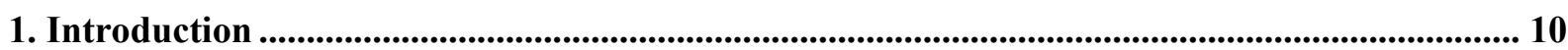

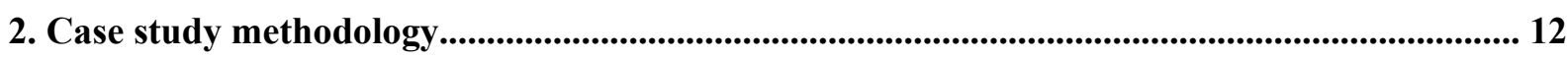

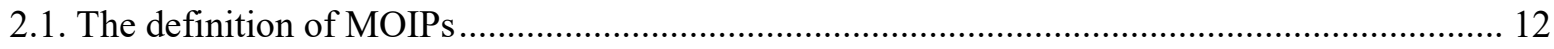

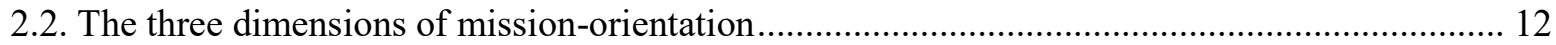

3. Framework conditions for mission-orientation in Japan................................................................. 14

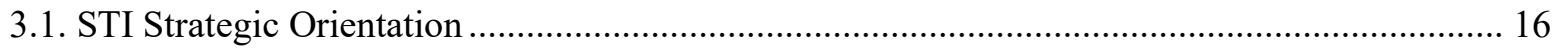

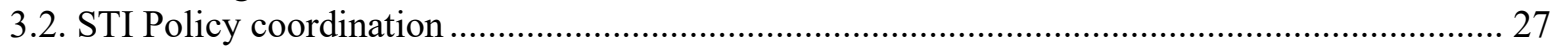

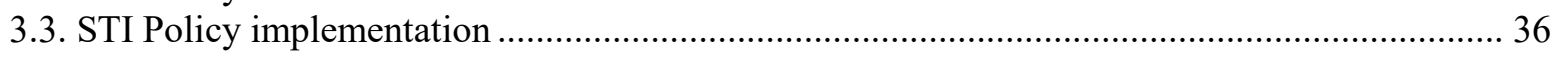

4. Mission-oriented policy initiatives in practice .................................................................. 41

4.1. The Cross-ministerial Strategic Innovation Promotion Program (SIP) ...................................... 41

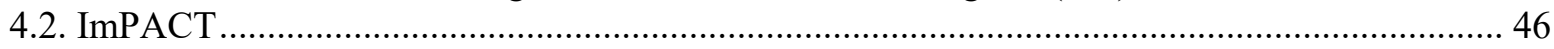

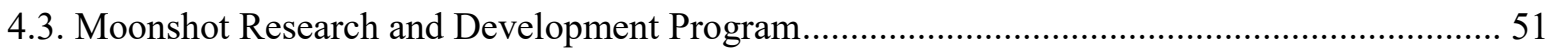

5. Conclusions and options for the future of the mission-oriented policy agenda in Japan ......... 56

5.1. Japan has become increasingly oriented towards societal challenge missions ........................... 56

5.2. Japan has gradually established a singular holistic governance system "from the center"........ 56

5.3. Japan has pioneered some purpose-built mission-oriented policy initiatives ............................ 57

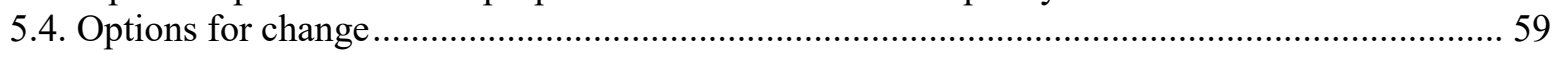

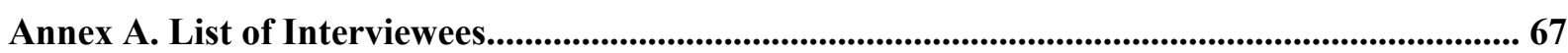

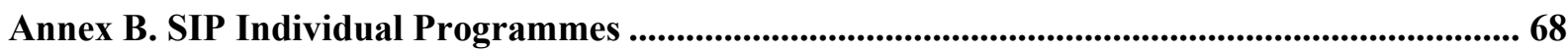

Annex C. FIRST Projects ........................................................................................................................... 69

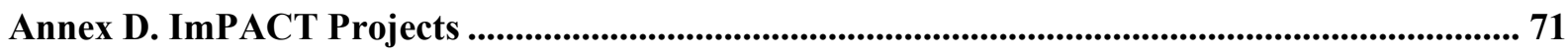

Annex E. Moonshot goals and targets ......................................................................................................... 72

Annex F. Challenges and opportunities of the SIP and ImPACT programmes ............................ 74

\section{FIGURES}

Figure 1. Structure of the case study report 


\section{6 | MISSION-ORIENTED INNOVATION POLICY IN JAPAN}

Figure 3. CSTI and its expert panels under the Fourth Basic Plan (2011-2015) 22

Figure 4. Government R\&D budgets by SDG-related category, $2018 \quad 24$

Figure 5. Overview of the different headquarters and the Integrated Innovation Strategy Promotion Council 32

Figure 6. Four simplified models of interministerial STI coordination in the Japanese context 33

Figure 7. Government budget allocations to R\&D (GBARD), (2019 and 2013)

Figure 8. Gross domestic spending on R\&D (GERD) (2018 and 2013) 37

Figure 9. GERD, financed by government (2013 and 2018 or latest) 37

Figure 10. Oriented and non-oriented government R\&D budget (2019 or latest year available) 38

Figure 11. Direct and indirect government support to business R\&D, 2018 and $2006 \quad 39$

Figure 12: Direct government funding of business R\&D and tax incentives for R\&D, Japan, 2000-18 39

Figure 13. Overview of the process, governance and main MOIP features of the Cross-ministerial Strategic Innovation

Promotion Program $\quad 42$

Figure 14. Generic governance structure of the SIP and one SIP individual programme 44

Figure 15. Overview of the process, governance and main MOIP features of the ImPACT Programme 47

Figure 16. Structure of governance of the ImPACT programme 49

Figure 17. Overview of the process, governance and main MOIP features of the Moonshot Research and Development
Programme

Figure 18. Portfolio of projects pursuing one Moonshot goal $\quad 55$

\section{TABLES}

Table 1. The three dimensions of mission-orientation $\quad 13$

Table 2. Japan's performance on the 17 SDGs according to the SDG index 23

Table 3. Strengths and weaknesses of the CSTP identified by a group of experts in $2011 \quad 28$

Table 4. Main features of selected MOIP initiatives in Japan $\quad 57$

Table 5. Main mission-orientation features of the current Japanese STI policy model 59

\section{BOXES}

Box 1. The origin of mission-orientation in Japan - Industrial policy during the catch-up period 15

Box 2. The role of the Science and Technology Agency (STA) in strategic orientation until $2001 \quad 20$

Box 3. The Fuel Cell Commercialization Conference of Japan (FCCJ) 30

$\begin{array}{lr}\text { Box 4. The FIRST Programme } & 48\end{array}$

Box 5. Lessons-learned from FIRST and ImPACT $\quad 50$ 


\section{Executive summary}

Japan has gradually developed and enhanced many of the essential features of missionorientation since the 1970s in particular in the last two decades. STI policy has become more top-down, with strong directionality and holistic coordination provided by the centreof-government bodies, in particular the Cabinet Office and the successive STI headquarters. As early as 2014, Japan launched some ambitious MOIPs, led by centre-ofgovernment.

This case study, undertaken as part of the OECD CSTP project on mission-oriented innovation policies (MOIPs), aims to assess the possible need for, as well as challenges and opportunities to mission-orientation in Japan. On this basis, it seeks to provide inputs into the discussions on how Japanese authorities could better promote a mission-oriented policy approach in order to effectively address societal challenges.

\section{Is there a need for mission-oriented innovation policies in Japan?}

Japan faces major societal challenges, which will call for significant technological and social changes. While Japan fares relatively well in international comparison with regards to progress towards reaching the 17 sustainable development goals (SDGs), significant challenges remain on nine of them (including Gender equality, Climate action, Affordable and clean energy). This has been acknowledged in strategic plans, not least in the Science and Technology Basic Plans which have become increasingly designed to address societal challenges. While this strategic orientation started earlier, the Fourth Basic Plan (20112015) has put even greater emphasis on sustainable growth and societal development in the aftermath of the recent Great East Japan Earthquake in 2011. The Fifth Basic Plan (20162021), inspired by the 'Society 5.0' vision, marked another significant step towards prioritising societal issues. Actual efforts towards achieving SDGs are less clear. Japan is, for instance, one of the countries that allocates a lower share of Government R\&D budgets to projects and activities that are related to health and societal issues. More generally, in international comparison, only a rather modest portion of the government appropriations dedicated to R\&D in Japan is considered as goal oriented (i.e. research reported by national authorities as contributing to specific socio-economic objectives).

Moreover, despite significant efforts, Japanese STI policy efforts to tackle societal challenges remain too fragmented and 'siloed' in different ministries' policy portfolios. Inter-ministerial policy co-ordination has been a long-standing priority in Japan. In the face of persistent silos, the government has gradually strengthened and extended the mandate of the centre-of-government bodies (including its successive high-level STI advisory councils) to allow for more strategic and integrated policy making. The government also created several 'thematic headquarters' under the Cabinet Secretariat and Cabinet Office (in health, IT, ocean, space, etc.). The multiplication of these headquarters in areas with strong relevance to STI policy also had some unintended consequences, such as an increase in complexity of STI governance.

\section{Does Japan have specific advantages for the design and implementation of mission- oriented innovation policies?}

The interest raised by mission-oriented policies in Japan in the last 10 years builds upon a long tradition of strategic STI policy making. During the catch-up period, the government implemented voluntarist industrial policies whereby it differentiated its mode of intervention according to each designated area in order to steer industrial activities towards the most promising directions. To do so, the government often led consultations to develop 
plans and "Visions", followed by the creation of a research consortium (e.g. the Very largescale integration consortium [VLSI], the Fifth Generation Project). Although confined to a given industry, research consortia had several features in common with MOIPs. The 'industry-targeting' model became less effective at the end of the 1980s as Japan was no longer among the frontrunner countries.

After a transition period when Japan favoured less targeted policies, and starting in the mid1990s, the Japanese STI policy model gradually adopted features that are consistent with and paved the way for - a new type of MOIP approach. Accompanying these changes, the governance of the Japanese STI system has become more challenge-oriented, centrally-led, and coordinated top-down, as well as increasingly precise and 'hands-on'. This evolution is in line with a recent trend of strengthening the institutional and financial capacity of central governments to support SDG implementation in several countries.

\section{Does Japan implement mission-oriented innovation policies?}

Following the 2012 elections, the new government tried to reinforce even more significantly the central power vis-à-vis the individual ministries and agencies by providing the Council for Science, Technology and Innovation (CSTI) with a large budget to operate its own STI programmes, notably the Cross-ministerial Strategic Innovation Promotion Program (SIP) and the Moonshot Research and Development programme ('Moonshot'). The SIP is a large multiannual national STI initiative created in 2014 to promote research, innovation and demonstration activities in an integrated way. It aims to both address societal challenges and foster economic growth, in areas where strong interministerial coordination is needed. Moonshot aims to promote disruptive innovations and tackle societal challenges. It has strong mission-oriented features such as the use of 'inspiring, imaginative and credible' missions (the 7 Moonshot goals), the adoption of a portfolio approach and stage-gate funding mechanism.

The adoption of fully-fledged mission-oriented programmes orchestrated by the Cabinet office is the last and certainly the most significant step in the government's effort to implement better targeted, coordinated and more effective STI policies. Japan has therefore acknowledged the opportunity of mission-oriented policies to address societal challenges more strategically and holistically. Even more, it has put this policy approach in practice in the last ten years, through bold and experimental initiatives.

\section{What could be next steps for mission-oriented innovation policies in Japan?}

Government's continuous efforts to improve STI policy orientation and coordination have significantly increased the complexity of the STI system governance and the associated transaction costs. There is a need to streamline the structure of STI governance, in particular with regards to the division of responsibilities between the different STI headquarters (CSTI on one side and the area-specific headquarters on the other side).

The strengthening of the 'command tower function' played by CSTI has somewhat reduced the involvement of ministries in the policy formation process, in particular when it comes to the final decisions and arbitrages. CSTI should be considered as a ground for experimentation to launch, test and improve new policy initiatives, such as missionoriented policies. Once well established and functioning, these policies could be transferred to a set of inter-connected ministries. CSTI could retain an important role in the overall holistic supervision and monitoring $\&$ evaluation of these initiatives.

The SIP and the Impulsing Paradigm Change through Disruptive Technologies programme (ImPACT) are two of the very few fully-fledged mission-oriented innovation policy initiatives worldwide ${ }_{2}$ which have been operating during an entire programmatic cycle. 
They offer the experience of two very different types of MOIPs. Following well-designed evaluations, other countries can learn from their respective strengths and limitations.

Finally, Japan could complement the current MOIPs led by the Cabinet Office with more bottom-up and challenge-based initiatives such as those experimented in Norway and Sweden for instance. 


\section{Introduction}

The project on mission-oriented innovation policy (MOIP) was launched by the OECD Committee for Scientific and Technological Policy (OECD-CSTP) ${ }^{1}$ in 2019. It aims to provide a comprehensive understanding of how governments try to address societal challenges through various types of MOIPs in different national and thematic contexts. Using a dedicated methodological framework, the project consists of two main types fieldwork:

1. Systematic investigations: identification and characterisation of MOIP initiatives in all OECD countries and beyond;

2. In-depth investigations: thorough analysis of mission-oriented policies in a sample of voluntary countries through case studies. To date, four countries have engaged in a partnership with OECD to conduct a 'MOIP case study': Austria, Japan, Korea and Norway.

The results of the project were published in February 2021 (Larrue, 2021).

The present document sets out the results of the Japan MOIP case study. The main objectives of this case study are to:

- identify and analyse the institutional factors that may foster or impede the design and implementation of MOIPs for societal challenges in Japan.

- systematically scan through the Japanese policy landscape to identify and characterise initiatives that match - to a greater or lesser extent - the MOIPs' definition.

The final goal of the case study is to identify the opportunities for and challenges to mission-orientation in Japan and contribute to discussions on how Japan could, if deemed necessary, strengthen its mission-oriented policy. This should help Japan to more effectively address societal challenges and meet national priorities.

The case study was undertaken with technical support from the Center for Research and Development Strategy, Japan Science and Technology Agency (JST-CRDS) and the Ministry of Education, Culture, Sports, Science and Technology (MEXT). An interview campaign took place in Tokyo in December 2019 (see Annex A).

This document has five main sections (Figure 1). Following this introduction, the second section synthetises selected elements from the project methodological framework, in particular the definitions of the main concepts used to structure the analysis. The third section assesses the so-called MOIP framework conditions, i.e. the extent to which the institutional setting in Japan influences the ability of the government to design and implement MOIPs. This section is structured along the three dimensions of mission orientation - strategic orientation, policy coordination and policy implementation - to address subsequently the following questions:

1. How Japan has currently and in the recent past set directions to achieve particular objectives of national importance, in particular those related to societal challenges;

2. How Japan coordinates STI policies across policy fields, communities and sectors;

3. How Japan implements specific STI policies and programmes that match to a greater or lesser extent the features of MOIPs as defined in this study.

The fourth section reviews three recent or on-going MOIPs in Japan: SIP, ImPACT and Moonshot. A last section recalls the main findings, concludes on opportunities and challenges of mission-orientation in Japan and proposes some options for the next steps. 
Figure 1. Structure of the case study report

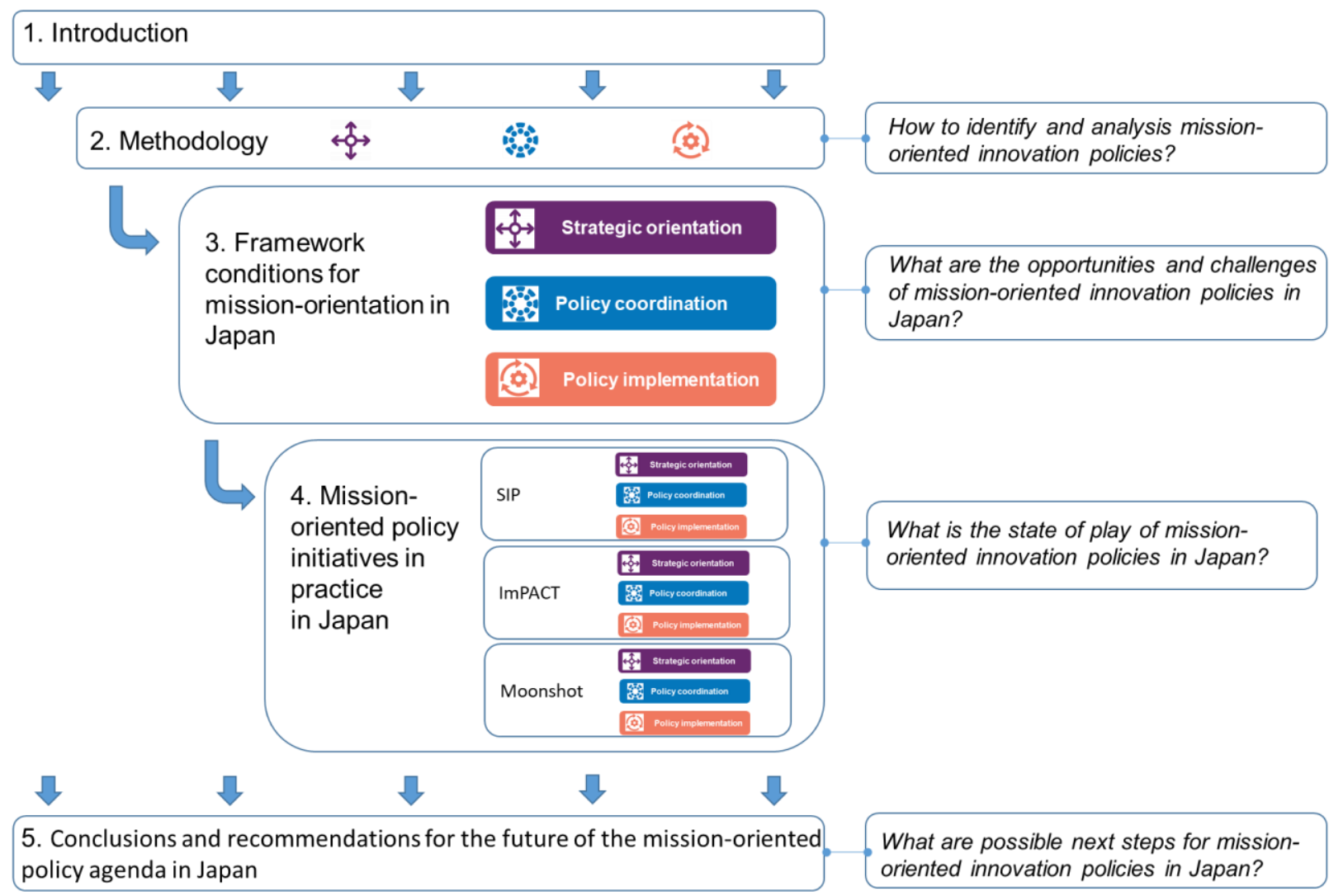




\section{Case study methodology}

The methodological framework developed in the context of the CSTP project on MOIPs is used to support and structure the case study.

\subsection{The definition of MOIPs}

The definition of MOIPs used in this project builds upon an extensive literature review and is consistent with the main research works conducted recently (European Commission, 2018a, 2018b, Mazzucato, 2018). A MOIP is defined as a co-ordinated package of policy and regulatory measures tailored specifically to mobilise science, technology and innovation in order to address well-defined objectives related to a societal challenge, in a defined timeframe. These measures possibly span different stages of the innovation cycle from research to demonstration and market deployment, mix supply-push and demand-pull instruments, and cut across various policy fields, sectors and disciplines (Larrue, 2021).

This definition can be broken down to isolate three main types of functions that MOIPs are expected to fulfil, along the three MOIP dimensions of Strategic orientation, Policy coordination and Policy implementation (see Figure 2).

Figure 2. The definition of MOIPs and the three MOIP dimensions

Coordinated package of research and innovation policy measures aiming to address societal challenges

2 spanning several stages of the innovation cycle from research to demonstration and market launch

13. using various instruments (supply-side and demand-side; top-down and bottom-up)

拨 crossing various policy fields (interministerial, cross-agency, etc.)

(C) targeted towards ambitious and concrete goals

3 in a defined time-frame

Strategic orientation

Orientate collective effort towards a well-defined challenge

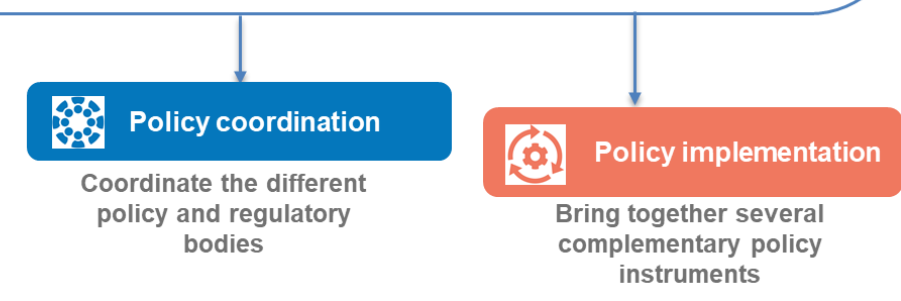

\subsection{The three dimensions of mission-orientation}

The definition of MOIPs encompasses three main dimensions (Table 1). These dimensions were used for fieldwork (design of templates and interview guidelines) and for analysis and delivery of results at national and initiative levels (structure of chapter 3 and 4). 
Table 1. The three dimensions of mission-orientation

\begin{tabular}{l|l}
\hline Policy coordination & $\begin{array}{l}\text { The ability to engage a wide array of public and private } \\
\text { actors in the selection of well-informed societal } \\
\text { challenge(s) and the legitimation of focused policy } \\
\text { interventions towards these challenges. }\end{array}$ \\
\hline
\end{tabular}




\section{Framework conditions for mission-orientation in Japan}

The MOIP framework conditions systematically define the national factors that influence the ability of a country to design, fund and implement MOIPs. These national factors pertain to the three dimensions that lie at the core of MOIPs: strategic orientation, policy coordination and policy implementation. The main underpinning hypothesis is that the forms and types of MOIPs in a given country can only be understood within:

- the national institutional setting in which they are embedded and that determine to a great extent what is politically and socially feasible at one point in time. Countries differ for instance in their capabilities to steer, fund and implement complex policies (such as MOIPs);

- the policy trajectory that has gradually formed them, moving forward through experimentation, negotiation and learning. These trajectories are driven by a number of factors, among others the general policy stance toward state intervention, the respective choice of policy instruments (e.g. generic vs. specific measures).

The analysis shows that, as Japan strived to catch-up with western economies until the 1980 s, public authorities have played a key role to steer industrial and innovation activities. The government demonstrated a strong capacity to support consensus towards common goals and promote cooperation to collectively achieve these goals. The policy implemented during this period share several features with mission-oriented policies: goal-driven and proactive interventions, steering of activities, policy measures tailored to the specific industry, hands-on approach to mobilise and support large public-private partnerships (Box $1)$. 


\section{Box 1. The origin of mission-orientation in Japan - Industrial policy during the catch-up period}

The leading role of public authorities in Japan's after-war recovery is well documented and widely acknowledged among policy makers, analysts and scholars. While the investment of Japan in basic research was still modest at the time and up until the 1990s, industrial policy played a key role in helping Japan's economy catch-up with Western economies. The authorities in charge of industrial policy - primarily the Ministry of International Trade and Industry (MITI, which became METI in 2001) - were not confined in a role of referee but acted as a real pilot organization for the "developmental state" (Johnson, 1982).

\section{Strategic orientation}

The government was actively involved in the creation of consensus on broad objectives, particularly regarding inter-sectoral shifts. Industry associations and various types of deliberation councils (shingikai), gathering small groups of experts from academia, public authorities and industry in order to discuss and formulate policy propositions, often played a significant role in this process. The Japanese government also formulated various plans and 'Visions' to develop and diffuse the long-term goals, federate actors toward these goals, instil confidence and establish the respective chain of responsibilities among industries (Watanabe, 2000; Committee on the History of Japan's Trade and Industry Policy RIETI, 2020).)

As Japan was becoming a growing leader on some high technology industries, MITI increasingly put the emphasis on technological development, under the assumption that new technologies and systems would become the foundations for future industrial development. While some of the priorities implemented by the government- at the time were related to social issues (pollution, traffic jams, water shortages, etc.), the need to fill the technology gap between Japan and other developed countries remained one of the main rationales for intervention during this period (Harayama, 2001). After the oil shocks, the diversification of new energy technologies also became a national priority.

\section{Policy coordination}

During the catch up period, clear and consensual 'development policy' goals alleviated some of the major policy coordination issues. Moreover, the need for interministerial coordination was less pronounced at the time. A rather clear division of labour guided the relationships between the authorities in charge of supporting basic and applied science (primarily the Ministry of education and the Science and Technology Agency [STA]) and those in charge of development (MITI and its agency NEDO).

The situation changed during the 1980s and especially at the beginning of the 1990s for several reasons. First of all, the persisting, and even worsening- economic recession called for significant reform of vertically integrated policies run by each ministry. More effective coordination was expected between MITI and the STA; as well as with other sectoral ministries in order to support the creation of new industries based on new knowledge and technology development (Kawamura and Takeda, 2014). Also, MITI gradually started relying more on general policies that could benefit on a range of industries (promotion of research-industry relationships), and less on its sector-specific policies (such as supercomputers for instance). This required greater efforts to cooperate with other ministries, including with the then Ministry of education (Elder, 2003). Moreover, the liberalisation of the economy increased the decentralisation and compartmentalisation of STI policies among different ministries, which led to significant efforts to "re-coordinate the economy" (Lechevalier et al., 2016).

\section{Policy implementation}

During the catch-up period, the government implemented a voluntarist policy whereby it differentiated its mode of action according to each designated area in order to steer industrial activities in the most promising directions. This vertical intervention became the essence of the 
Japan's industrial policy, defined as the "custom design of policy instruments to fit the different priorities, needs and circumstances of individual industries" (Okitomo, 1989).

In high tech industries such as semi-conductors or new energy technologies, policies were often followed by the creation of a research consortium - or 'Big Project' as they were commonly named in Japan. These large-scale pre-competitive programmes were essential in realising the goals of the plans or 'Vision' and the government extensively used research consortia to foster and steer cooperative R\&D of private firms related to new strategic technologies (Watanabe, 2000). These state-led partnerships gathered private companies, including competitors, at the level of a whole industry or part of it, together with universities and national research laboratories in order to pursue joint research for several years. Through the establishment of these publicprivate partnerships, the objective of policy makers was to "organize major industrial sectors concerned with solving technological problems common to the sector as a whole, or to a smaller group of major companies within the sector" (Ito, 1991). The authorities in charge of industrial policy; played a very influential role in forming and shaping the R\&D consortia, not only ensuring the integration of the 'competitive partners' companies-, but also sometimes actively recruiting the consortium's participants (Hane, 1993).

These initiatives were mainly used to strengthen national industries in the face of growing international competition, notably in IT sectors (the Very large-scale integration consortium (VLSI), the Fifth Generation Project). However, after the two oil shocks they were also mobilised to respond to the growing environmental concerns. Among the most emblematic research consortia in these areas were the Sunshine, Moonlight and New Sunshine Programs aiming to support energy technology R\&D, respectively in the 1970s, 1980s and 1990s.

When Japan reached the technological frontier in the 1980s, powerful companies that took the lead in several technological fields increasingly asked the government to confine its intervention to horizontal policy, e.g. using incentives for energy consumption reduction, setting antipollution regulations (de Maricourt, 1995). Research consortia were considered by many as no longer needed, and their downsides (administrative rigidities, lack of independence, reluctance to cooperation between competitors, national scope) were deemed exceeding their expected contribution to firms' future competitiveness. The number of research consortia decreased drastically and the government focused on providing strategic guidance and improving the framework conditions for innovation rather directly intervening in firms' strategies.

\subsection{STI Strategic Orientation}

As the goal-oriented policy model became less effective at the end of the 1980s when Japan became an industrial- leader, the government shifted away from steering research and innovation activities towards a less interventionist policy approach. It tried to limit its role to the support of basic science and the provision of adequate framework conditions for STI activities, notably through the Basic Plans launched every 5 years since 1996.

The successive Basic Plans have significantly evolved throughout the last 25 years, gradually adopting features that are consistent with a MOIP approach. Along these changes, the governance of the Japanese STI system has become more result-oriented, centrally led and coordinated top-down, as well more precise and 'hands-on':

- Basic Plans are increasingly geared towards specific goals (in particular those related to societal challenges) instead of being structured around disciplines or sectors;

- The Cabinet Office, notably through its successive high-level STI councils (CSTP, then CSTI), has become prominent to develop and implement the Basic Plans;

- The Basic Plans - which only provided the general strategic framework - are now accompanied by and implemented through precise annual action plans. 


\subsubsection{The evolution of the Japanese STI policy toward a challenge-based approach}

\section{5 years of $S \& T$ basic plans}

As Japan reached the technological frontier, the government first put more emphasis on basic science and knowledge transfer in the 1990s. Japan started by prioritiszing sciencebased industries (Harayama, Carraz, 2018). A wave of structural reforms was initiated in 1995 with the passing of the above mentioned Science and Technology Basic Law that called for 5-year strategic Science and Technology Basic Plans (hereafter, the 'Basic Plans').

The First S\&T Basic Plan, covering the period 1996-2000 focused notably on the expansion of the research system (nearly doubling the competitive research funding), the improvement of the research infrastructure and science-industry linkages (Government of Japan, 1995). Contrary to its predecessor that did not specify any priorities, the Second Basic Plan (2001-2005) established a list of eight prioritised R\&D areas (Government of Japan, 2001) $)^{2}$. Although it seemed to be a step back towards previous practices, it marked a gradual change with respect to the industry targeting policy as the focus was not anymore primarily on specific technological development or industries, but on addressing specific national priorities (international competitiveness) and social problems (environmental issues, ageing, low-birth-rate, security issues). ${ }^{3}$ Moreover, since technological progress is not sufficient to address social issues such as ageing, a "policy package' that includes for instance regulatory reform was initiated along the S\&T programmes (Motohashi, 2011). In line with the concept of 'comprehensive S\&T policy' that was underpinning it, the Second Basic Plan offered " $a$ vision to apprehend technological and societal changes" (Carraz, Harayama, 2018).

This trend was pushed further in the Third Basic Plan (2006-2010) which became increasingly issue-based. This trend originated from growing environmental and societal concerns but also more generally from the need to demonstrate actual results after 10 years of Basic Plans. The Plan kept the same eight priority areas but provided guidance for "intrasectoral prioritisation"; on the basis of the linkages between these priority areas and broader policy goals. Under the supervision of a high-level advisory council, the Council for Science and Technology Policy (CSTP), Project Teams were appointed in each of the eight priority fields to provide further guidance. All together, 62 Strategic S\&T Priorities and 273 "important R\&D themes" resulted from the work of the Project teams; with identification of the leading ministries in charge and directions for the design of support measures (Stenberg and Nagano, 2009). Although Basic Plans do not specify budgets per areas, the share of the total public R\&D expenditures accounted for by the four prioritised research areas, gathered under the label of "Policy mission-oriented S\&T", increased significantly (Stenberg and Nagano, 2009).

The Fourth Basic Plan (2011-2015) "made a radical transition from discipline-based to issue-driven STI policy" (Sato and Arimoto, 2015). Indeed, in the aftermath of the recent Great East Japan Earthquake in 2011, the Fourth Basic Plan put even more emphasis on sustainable growth and societal development along with initiatives to further develop and improve the research system as a whole. It started from the premise that although the second and third Basic Plans have led to the development of new technologies in the eight priority areas, this have not always resulted in progress toward solving social issues. The Fourth Basic Plantherefore proposed to adopt a more pronounced and formal issue-based approach: the government should first identify the essential issues to address, then formulate responsive strategies and facilitate the $R \& D$ activities that are relevant to tackle 
these issues. The Plan designated three key issues to be tackled: recovery and reconstruction from the disaster, 'green innovation' and 'life innovation.'

The current Basic Plan - the fifth one covering the period 2016-2020 - is the first plan formulated by the new Council for Science, Technology and Innovation (CSTI) that replaced the CSTP in 2014. It marks another significant step towards a prioritisation based on societal challenge and inspired by a broad vision rather than by segmented technological fields (Government of Japan, 2016). A large portion of the Plan is structured around the central objective of the achievement of the 'Society 5.0'. The latter is defined as a 'humancentred' society capable of achieving both economic growth and addressing social challenges. It responds to a wide variety of social needs and aims to help Japan prepare for the rapid changes triggered notably by the on-going digital transformation. Along the Society 5.0 overall framework, the Fifth Basic Plan sets two types of priorities:

- Continuing the trend set by its predecessors, the Plan includes 13 'issue-oriented' priorities to address societal challenges. Although based on the need of the Society 5.0 or specific societal challenges, these priorities remain however numerous and very broad,-_basically encompassing the whole spectrum of potential options. ${ }^{4}$

- Somewhat reverting to old practices, the Plan also contains 14 'technologyoriented' priorities that are necessary to achieve the Society 5.0. These priorities are in line with MEXT's Council for Science and Technology ${ }^{5}$ recommendations to include in the Plan some 'national critical technologies' to be promoted strategically by the government, with a long-term focus (MEXT, 2015). More generally, during interviews, MEXT officials emphasised the importance of striking a balance between the need to address societal challenges by directing STI activities towards them and the need to strengthen excellence in key research and technology fields. While the jurisdictional authority on the development of the Basic Plans has moved from MEXT to the Cabinet Office since the creation of the CSTI in 2014, MEXT conserves its undisputed prerogatives for matters directly related to the science system.

The Plan seemed to have had a strong impact on various policies as well as in some of the major research and innovation organisations, including among industry leaders (Carraz, Harayama, 2018). It had at least a structuring effect well beyond the sole STI area as evidenced by the fact that it was taken up as one of the main components of the governmentwide Growth Strategy in 2017. This remains however difficult to be assessed precisely since the monitoring framework still needs to be improved (see infra, sub-section 'Goals and objectives').

The sixth Basic Plan is currently under development and is due in early 2021. Discussions have started on system-wide issues and will proceed with negotiations on specific areas.

\section{The comprehensive and integrated innovation strategies}

In 2012, the Liberal Democratic Party won the general elections with a programme based on the implementation of a growth strategy to drive economic recovery. Innovation being one of the main driver of this strategy and its corresponding policy - the so-called Abenomics - the new government led by ABE Shinzō at the time decided to make significant changes to the governance of the STI system. While this was already an ongoing trend as shown by the gradual evolution of the Basic Plans, the reforms led by the new government in 2013 and 2014 marked a step change toward a stronger and more impactful strategic steering of STI policies. 
As regards strategic orientation an important change was the development of annual action plans to refine the priorities for the coming year in line with the 5-year Basic Plans. While the Basic Plan establishes the mid- to long-term STI policy orientation, the so-called Comprehensive Strategies on Science, Technology and Innovation sets the measures that should be given particular importance in the coming year, taking into account the current context. The first and second Comprehensive Innovation Strategies in 2013 and 2014 were also the occasion for the newly elected government to start introducing its reforms without having to wait until the release of the Fifth Basic Plan due only in 2016. It includes notably the first steps towards the overhaul of the STI budgeting system (see Policy Coordination) and the creation of two new STI programmes (see Policy Implementation). More generally, the Comprehensive Innovation Strategies reiterate the focus on a result-oriented policy, whereby STI actively contributes to tackling societal challenges and ensuring Japanese leadership in high growth area.

The 2015 Comprehensive STI Strategy was the first opportunity to revert to the normal situation where the annual plan follows up on the 5-year plan. ${ }^{6}$ This Strategy and its successors in 2016 are broadly structured along the chapters of the $5^{\text {th }}$ Basic Plan. They include both priority challenges and priority technologies that are broadly consistent from one year to the other, with some specific annual emphasis to guide the coming year budget formation. The 2015 Strategy for instance lists 11 priority systems/platforms. ${ }^{7}$ The 2017 Comprehensive Innovation Strategy includes disciplines and technologies to support these platforms that are deemed crucial for the Society 5.0. ${ }^{8}$ The 2016 and 2017 Comprehensive Strategies include several priorities that relate to societal challenges:

- ensuring stable energy, resources and food

- achieving a sustainable society to handle hyper-aging, depopulation

- improving competitiveness in manufacturing and creative industries

- realizing the efficient and effective maintenance, upgrading, and management of infrastructure

- realizing a resilient society in the face of natural disaster

- addressing national security issues

- addressing global challenges and contributing to global development

- pioneering strategically important frontiers (ocean and space)

In 2018, the annual Comprehensive Innovation Strategies changed name to become the Integrated Innovation Strategies. This change reflects the need to widen the scope of the annual actions in order to include all policy fields beyond those directly in charge of research and innovation. This reform came along with changes in the governance of the STI system (see Policy Coordination). The 2018 and 2019 Integrated Innovation Strategies' structure and content do not mark an abrupt break relatively to the former Comprehensive Strategies. The slight changes confirm the trend towards a more straightforward presentation of 'major objectives' and 'major policies', both with clear deadlines.

In line with the Fifth Basic Plan, the 2018 and 2019 Integrated Innovation Strategies maintain a balance between issue-oriented priorities that aregeared toward the achievement of the Society 5.0 and priorities in fundamental research and technology fields. The latter remain very broad: AI Technology, Biotechnology, Quantum Technology, Environment and energy, Safety and security, Agriculture, Other important technology (satellite data, Oceanic data, space startups, microplastic countermeasures) (Ueyama, 2018; Government of Japan, 2019). 


\subsubsection{Advisory and agenda setting bodies}

Important organisational changes came along with significant reforms of the research and industrial policies in 2001. There was an important reshuffling of policy portfolio between ministries - not least between METI and the authorities in charge of research policy following the creation of MEXT. ${ }^{9}$ Furthermore, the government created new agencies and reformed some universities and national institutes. Most importantly for the purpose of this study, the high level STI strategic advising body was transformed to allow for a progressive strengthening of its role as the headquarter of research and innovation policies.

\section{The Council for Science and Technology Policy (CSTP)}

The Council for Science and Technology (CST) was one of the early advisory councils in charge of setting priorities. It was chaired the Prime Minister and tasked with examining and preparing government wide science and technology policies. It was supported by the Science and Technology Agency (STA), which took care of its secretariat.

\section{Box 2. The role of the Science and Technology Agency (STA) in strategic orientation until 2001}

The Science and Technology Agency (STA) was established within the Office of the Prime Minister in 1956. At the time of its establishment, the Agency's main mission was to promote the research and development of nuclear energy which was at that time a top priority in Japan. Subsequently, the country's R\&D priorities were taken charged of by STA, and space exploration, ocean development, and life science were defined asemerging, large and high-risk programmes.

In order to manage these major national thematic technological programmes, STA developed "public corporations" which had unique organisational and budgetary structures to conduct focused R\&D projects. STA promoted large-scale, long-term R\&D programs with significant expected technological and socioeconomic impacts.

STA was also in charge of coordinating R\&D across the government as a whole, and served as the secretariat of the Science and Technology Council. In order to carry out such comprehensive coordination, the Science and Technology Promotion and Coordination Fund was developed and appropriated to STA. The fund played a major role in the actual implementation of such comprehensive coordination, including promotion of R\&D of emerging interdisciplinary fields, launch of new type of R\&D programs and initiatives such as Exploratory Research for Advanced Technology (ERATO) and Human Frontier Science Programs (HFSP), establishment of the launch of the internet in Japan, and promotion of mobility of researchers across national borders.

STA pioneered many of the mechanisms and measures for government-wide planning, coordination, and implantation of science and technology policy, which are currently undertaken by the CSTI.

Source: Takeyasu Y., Okuma K., Arimoto T., Kuniya M. (2009), History of Science and Technology Agency, The Science News, Tokyo.

The Council for Science and Technology Policy (CSTP) was established in January 2001 together with the establishment of the Council for Economic and Fiscal Policy (CEFP), which gives an idea of the importance granted to STI policy matters. The creation of these two councils was part of a larger agenda aiming to strengthen the function of the Prime Minister as well as the Cabinet Office (Stenberg and Nagano, 2009). CSTP was located within the Cabinet Office to lead the agenda setting process and support the interministerial 
coordination of STI policies. One important task of the CSTP was the drafting of the Basic Plans. The CSTP replaced the former Council for Science and Technology (CST) with a stronger mandate and wider competences as well as more representatives from the private and economic sectors. While the CST met twice a year, the CSTP held meetings headed by the Prime Minister almost once a month (NAP, 2009). Six out of fifteen members were ministers within the Cabinet and four other members were executive members, i.e. they are appointed to work full-time for CSTP. While meetings are short and dedicated to taking official policy decisions, the four executive members, a strong secretariat of about 100 staff, a dedicated budget to commission studies and several expert panels to deliberate on specific policy issues give the CSTP a strong and hands-on role that goes beyond simply providing advises to the government.

Gradually, the government acted to strengthen the role of the CSTP as STI 'Headquarter'. The 2013 Comprehensive Strategy included specific measures to empower CSTP both in terms of authority and budget. Contrary to its predecessor and to most high-level strategic STI committees in OECD countries and beyond, the mandate of CSTP was no longer only focused on strategic orientation functions. It was granted two new roles that allows it to play an increasingly prominent role in policy coordination and policy implementation:

- intervention in the annual budgetary allocations, reviewing the budgetary requests from the different ministries (see section on 'policy coordination');

- direct involvement in the governance, funding and implementation of key STI programmes (see section on 'policy implementation').

\section{The Council for Science, Technology and Innovation}

In 2014, the new political majority further reinforced the role of the Prime Minister advisory body when CSTP became the Council for Science, Technology and Innovation. While reinforcing the prerogatives of the central STI 'control tower' had been a priority for several years already, the CSTP was still facing significant challenges for holistic coordination. Even before the formal change of its name, CSTP took charge of drafting the Comprehensive Strategy on S\&T and Innovation every year since 2013, which gave it more direct power on strategies and policies. ${ }^{10}$ Furthermore, its role in the development of the Fifth S\&T Basic Plan was strengthened relatively to MEXT in 2015. MEXT conserved its undisputed power only for matters directly related to the science system (this is to say, on the universities and some national research institutes). Most importantly, CSTI became in 2014 responsible for the steering and implementation of two newly created "National Emphasis Programmes": the Cross-Ministerial Strategic Innovation Promotion Program (SIP) and the Impulsing PAradigm Change through disruptive Technologies program (ImPACT) (see 'Policy implementation' chapter).

The CSTI, like its predecessor, is supported by a strong secretariat of about 100 staff coming from other parts of the government for about 2 to 3 years in general, as well as from the private sector. Its membership varies since 2014. It can have at most 15 members, including the Prime Minister and 6 other Cabinet members, and 8 members including at most 4 members appointed full-time to work for the Council (reduced to one currently). The Government reinforced again the Council's mandate at the occasion of its refoundation. Its work is informed by several expert panels and working groups that are mobilised on a need basis (Figure 32). For instance, the CSTI established a Working group for new biotech policy. It held four meetings between December 2017 and February 2018 to formulate a draft of the Bioeconomy Strategy in June 2018. It is interacting with about 14 ministries that intervene in STI activities in their respective area. 
Figure 3. CSTI and its expert panels under the Fourth Basic Plan (2011-2015)

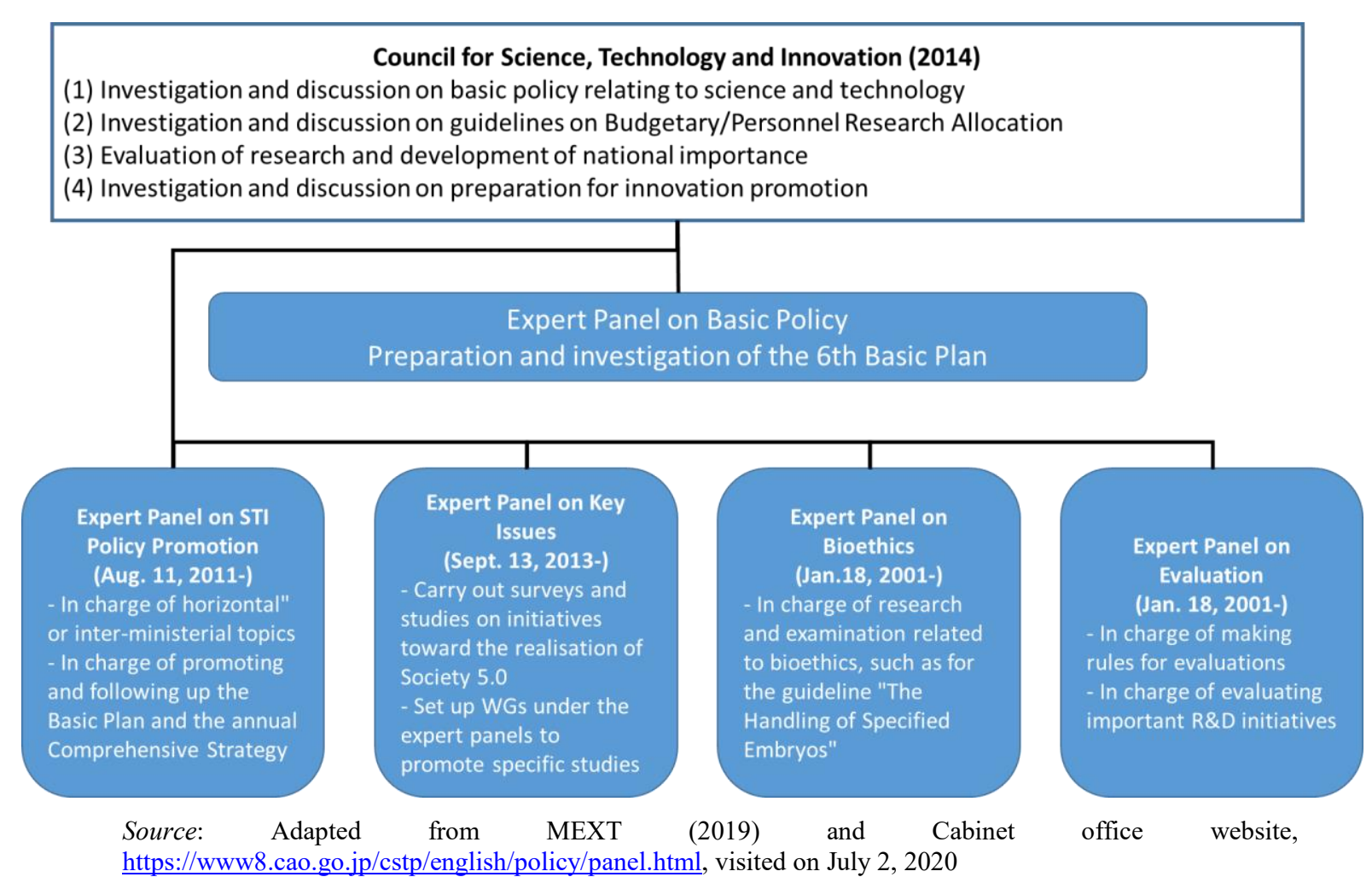

https://www8.cao.go.jp/cstp/english/policy/panel.html, visited on July 2, 2020

\subsubsection{STI to address societal challenges in Japan}

The analysis of the Basic Plans have shown that government efforts to support research and innovation have been in recent years increasingly directed towards societal challenges in the last two decades. Japan faces major societal challenges that will call for significant technological and social changes.

Japan fares relatively well in the SDG index (in international comparison) that assesses countries' performance with regards to indicators associated to the 17 sustainable development goals (SDGs). It ranks at the 17th position out of 193 countries - Sweden, Denmark and Finland reaching the 3 first ranks (Korea ranks at the 20th position). Nonetheless, significant or major challenges remain on nine SDGs (Table 2). The OECD 'distance to SDG' report is more positive (OECD, 2019a). Based on an analysis of 97 of the 169 SDG targets, Japan had achieved in 201915 of the 2030 targets, and many of the remaining distances to targets were deemed small. At SDG level, Japan appears on average closest to reaching goals on Water (goal 6) and Infrastructure (goal 9). On the other hand, Japan is furthest from the goals on Gender Equality (goal 5) and Reducing Inequality (goal $10)$. 
Table 2. Japan's performance on the 17 SDGs according to the SDG index

\begin{tabular}{|l|l|}
\hline Status & SDGs \\
\hline SDG achieved & SDG 4 Quality education \\
& SDG 9 Industry, innovation and infrastructure \\
& SDG 16 Peace, justice and strong institutions \\
\hline Challenges remain & SDG 1 No poverty \\
& SDG 3 Good health and well being \\
& SDG 6 Clean water and sanitation \\
& SDG 8 Decent work and economic growth \\
& SDG 11 Sustainable cities and communities \\
\hline Significant challenges & SDG 2 Zero hunger \\
remain & SDG 7 Affordable and clean energy \\
& SDG 10 Reduced inequalities \\
& SDG 12 Responsible consumption and production \\
\hline Major challenges remain & SDG 5 Gender equality \\
& SDG 13 Climate action \\
& SDG 14 Life below water \\
& SDG 15 Life on land \\
& SDG 17 Partnerships for the goals \\
\hline
\end{tabular}

Source: SDG Index, consulted on September 10, 2020, https://dashboards.sdgindex.org/profiles/NOR

Climate action (goal 13) is among the SDGs for which challenges remain in the SDG Index and OECD 'distance to SDG' report. Greenhouse gas emissions in Japan are particularly affected by electricity generation, powered by fossil fuel further to the Fukushima nuclear disaster. As part of the Paris Agreement, Japan has committed to a $26 \%$ percent reduction of greenhouse gas emissions in 2030 compared with the 2013 level (equivalent to 15\% below 1990 level). More recently, the government announced the goal of realising a carbon-neutral, decarbonized society by 2050 , and METI formulated the industrial policy "Green Growth Strategy towards 2050 Carbon Neutrality" in collaboration with related ministries and agencies. ${ }^{11}$ This is to be compared to the commitment made by Norway and Austria to become carbon neutral by 20302040 respectively. ${ }^{12}$ The EU aims to become climate-neutral by 2050 building upon its March 2019's resolution on climate change.

The allocation of R\&D public funds accross themes shows that Japan is one of the countries that allocate a lower share of Government $R \& D$ budgets to projects and activities that are related to health and society issues. A higher share in international comparison is allocated to planet and infrastructure. As in almost all countries, most of the government resources are directed towards industry and knowledge (Figure 4). 
Figure 4. Government R\&D budgets by SDG-related category, 2018

\section{As a percentage of total GBARD}

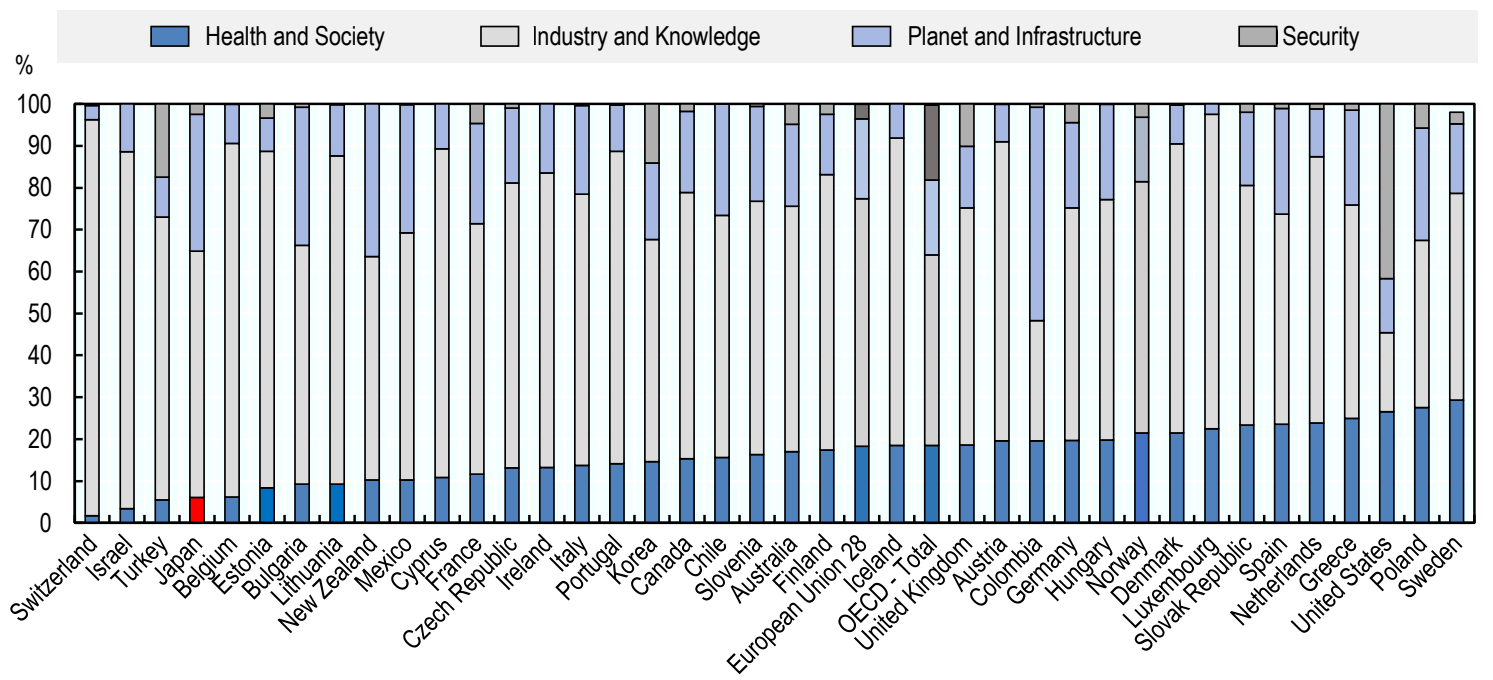

Source: OECD, Research and Development Statistics Database, http://oe.cd/rds, (accessed on 25 January 2021) Notes:

Note by Turkey:

The information in this document with reference to "Cyprus" relates to the southern part of the Island. There is no single authority representing both Turkish and Greek Cypriot people on the Island. Turkey recognises the Turkish Republic of Northern Cyprus (TRNC). Until a lasting and equitable solution is found within the context of the United Nations, Turkey shall preserve its position concerning the "Cyprus issue".

Note by all the European Union Member States of the OECD and the European Union:

The Republic of Cyprus is recognised by all members of the United Nations with the exception of Turkey. The information in this document relates to the area under the effective control of the Government of the Republic of Cyprus.

This is consistent with a more granular analysis of the same database. Japan is particularly active in the area of Industrial production, technology, energy and infrastructures, which represents about $28 \%$ of its Government R\&D appropriations. This is to be compared with $36 \%$ in Korea, $18 \%$ in Austria and 12\% in Norway.

\subsubsection{Strategic policy intelligence, consultations and monitoring}

\section{Strategic policy intelligence}

Strategic policy intelligence is the capacity to produce and analyse the information governments need to feed into strategy formulation and policy implementation and make "good" policy decisions. It comprises statistical data, studies and the results of policy monitoring and evaluation, and also builds on consultations with experts and multiple stakeholders (from implementers to various groups within civil society at large) to guarantee their buy-in. This requires sufficient resources both in terms of competences (increasingly those related to the intensive use of digital technologies and data) and funds.

During the catch-up period, the visions and policies of the Government that supported national growth were developed through multiple stages of consultation and deliberation in specific councils (shingikai) formed by ministries. In 1995, 215 of these councils existed, each of them including various committees and sub-committees (Schaede, 2000, p. 16). 
However, some authors raised concerns about the truly open nature of these consultations. It has been shown through several case studies that these councils were in fact sometimes used as a tool for the ex post legitimisation of government's decisions (Vogel, 1996). Shingikai became also increasingly criticised for being too formal and rigid, unable to adapt to arising needs and break away from vested interests of industrial or academic communities. As a result, the Government reformed the legal base underpinning these councils and drastically reduced their number. In 2006, there were only 110 remaining ones (Yamaya, 2015).

Strategies and plans in Japan formulated by the Cabinet Office or by individual ministries and agencies benefit from numerous studies (including benchmarking, roadmaps, foresight, etc.) carried out by research institutions such as the Center for Research and Development Strategy (CRDS), the National Institute of Science and Technology Policy (NISTEP) and the Technology Strategy Center (TSC). ${ }^{13}$ In line with the shift from a sectoral or disciplinary approach towards a challenge-based policy approach, the method of providing inputs to the various strategies and plans also changed. Japan has a long and strong tradition of foresight and roadmapping and makes increasing use of backcasting methods to determine priority technology fields based on the prior identification of social needs and challenges. A bidirectional approach mixing forecasting and backcasting (called 'Allcasting') was used for instance by TSC in the bioeconomy area (Kato, 2019).

\section{Stakeholder engagement}

Japan does not have a long tradition of involving stakeholders in policymaking but has made progress in recent years. According to OECD statistics, the engagement of stakeholders in developing regulations was still in 2017 far below the OECD average $(0.7$ in Japan against 2.2 in OECD) (OECD, 2019b).

The preparation of Basic Plans lasts about a year and includes several steps for consultation. This process has evolved overtime to become more inclusive, involving a wider array of policy makers and stakeholders through hearings, symposium and other types of events. The preparation of the Fifth Basic Plan was initiated with a new methodological approach. It consisted of brainstorming discussions among CSTI's executive members and those of its Expert Panel on Basic Policy and it was supported by commissioned studies with a view of identifying shared guiding principles (Carraz, Harayama, 2018). However, these consultations remain for the most part limited to public authorities, academics and, increasingly, private companies. The wider public is barely involved in the formulation of Basic Plans.

The Sixth Basic Plan currently under development starts from broad consultations of the main actors of the S\&T system and a thorough review of its predecessor. A first draft of the Plan will be available for public comments at the end of the year 2020. The process is led by CSTI's Expert Panel on Basic Policy to which several working groups (such as the WG on Institutional Issues that deal with governance issues) and sub-working groups report.

\section{Monitoring and evaluation against goals and objectives}

The Basic Plans are voluntarily broad and remain very wordy and discursive, sprinkled with concepts. The setting of precise targets apparently raised lively debates between different communities at the time of the elaboration of the Fifth Basic Plan. Part of the scientific community was reluctant to set targets that would be too directional as it was considered as possibly hindering the academic freedom. It could also add to the administrative reporting burden and lead to excessive focus on one possible research 
outcome. In the end, only eight system-wide input targets were included. ${ }^{14}$ The Plan also contains an overarching R\&D expenditure target of at least $4 \%$ for total R\&D investment as a share of GDP (R\&D intensity) and 1\% for governmental R\&D investment as a share of GDP. In 2018 , the total R\&D intensity was at $3.26 \%$ and government R\&D intensity was only at $0.51 \%$. Taking 2018 as the baseline, reaching the $1 \%$ target called for an increase of the government R\&D budget of about 900 billion yen (300 billion yen per year over 3 years) by the end of the Fifth Basic Plan in 2020 (Ueyama, 2018)..

Japan has a traditionally weak system and culture of evaluation of public policy both overall and specifically in the STI policy field (Woolgar, 2012). The increasing complexity of STI policies might even have worsened this limitation (Kang et al., 2019). Most evaluations remain closer to monitoring than evaluation, are internal evaluation which is not always publicly available. Academic researchers perform some evaluations of STI support schemes calling for complex quantitative evaluation techniques.

The CSTI, like its predecessor the CSTP, plays a role in the evaluation of large R\&D programmes (over Yen 30bn of total budget - about Euro 250m) and has a sub-committee dedicated to this task. For instance, in 2018 CSTI conducted an interim evaluation of the large-scale R\&D project "Flagship 2020 Project development of the supercomputer to succeed the K computer", started in FY2014. It also validated the methodology and execution of the second stage gate evaluation by METI of the large-scale R\&D project "Innovative Structural Materials Research and Development" (MEXT, 2019).

The Fifth Basic Plan has an integrated monitoring system whose results feed into the annual action plans and in the development of the next Basic Plan. The CSTI launched a Special Review Committee to monitor the progress towards the Basic Plan's targets. A report assesses the progress accomplished throughout the Fifth Basic Plan and highlights the main research and innovation successes. The report pointed out that Japan did not achieve the R\&D investment target of $1 \%$ of GDP, and that the increase in R\&D expenditures in Japan is slow compared to other countries, including the US and China. The report also concluded that Covid-19 crisis highlighted that Japan is lagging behind the other developed countries in digitalisation.

With the annual action plans being more practical and increasingly result-oriented, they include numerous targets. These targets are consistent with the Fifth Basic Plan goals and are the same each year for the sake of consistency. For instance, the 'creation of knowledge' component related to university reforms features target values such as the tripling of the amount of research contracts in 2014 between private enterprises and universities or national research institutes by 2025 , or increasing to over $50 \%$ the time spent by assistant professors in research activities.

The Ministry of Health, Labour and Welfare (MHLW) and the Headquarters of Health and Healthcare under the Cabinet Office set specific goals in the health and healthcare R\&D area. Some of these goals are close to those serving as missions in some MOIPs in other countries. For instance, the Healthcare Policy includes the following objectives (Cabinet Office, 2017):

- Extend the nation's health expectancy by one year or more by 2020 ;

- Reduce the number of citizens with metabolic syndrome by $25 \%$ from FY2008 by 2020;

- Increase the health screening rate (for the 40-74 age range) to $80 \%$ (including specified health check-ups) by 2020 . 


\subsection{STI Policy coordination}

Partially based on deeply rooted features of the Japanese culture, policy coordination has been a long-standing priority in Japan. This has resulted in numerous deliberative councils during the catch-up period, public-private sectoral coordination platforms, various roadmapping exercises, etc. The mobility of policy officers in ministries and in the central administrations is meant not only to increase their transversal skills but also to enhance communication and cooperation within a vast network of former colleagues. One long established priority was - and is still is - to enhance collaboration between MEXT and METI (and their agencies) in order to promote science and technology and innovation in an integrated manner. More recently, the scope of policy coordination extended to sectoral ministries as more emphasis has been put on tackling societal challenges. Since some of the barriers to interministerial coordination persisted, the reaction of successive governments was to strengthen the role of the high-level STI councils, CSTP, then CSTI. As it is the case for strategic orientation, CSTI was progressively granted more prerogatives for holistic coordination, for instance in the process of formation of ministries' budgets. These extended competencies and the creation of new central policy bodies in the Cabinet Office to support policy coordination in priority areas tend however to raise the complexity of the governance of the STI system.

\subsubsection{Horizontal policy coordination through the Cabinet office's STI advisory bodies}

\section{A new model for stronger and wider holistic coordination}

Since 1995, the Science and Technology Basic Law and the S\&T Basic Plans are meant to guide the new and more cross-ministerial STI policy (Kawamura and Takeda, 2014). More recently, the shift of STI policy focus towards societal challenges has stressed the issue of holistic coordination including not only STI authorities but also sectoral ministries that have strong prerogatives in related areas (environment, water, agriculture, etc.).

The need for better STI policy coordination also led to more top-down policy and the strengthening of the role of the central government authorities, i.e the Prime Minister Office and, even more, the Cabinet Office (Kawamura and Takeda, 2014). The general idea rather consistent throughout the different ruling governments for the last 20 years - was not to implement a new top-down approach led by the Cabinet Office but to rely on and coordinate the various public authorities in the different policy areas.

One important element of this model was the gradual reinforcement and extension of the mandate of the high-level STI advisory councils. During the 1990s, the CST already had the task of coordinating the various public ministries and agencies but was not in a position to arbitrate different points of view. This was partially due to its supporting secretariat which, although attached to the Cabinet Office, was ensured by the Science and Technology Agency. Therefore, the permanent staff of CST on the other hand was limited in both number and competency. In practice, MOF played de facto the role of referee of different interests at times of budget negotiations (Harayama, 2001).

\section{The gradual strengthening of the horizontal coordination functions of CSTP and CSTI}

As mentioned earlier, acting as the STI 'control tower' or 'headquarter' under the Prime Minister's leadership became one of the main function of CSTP and its successor. While CSTP's influence heavily depended on the leadership of the Prime Minister, it also had a bargaining power of its own that was potentially stronger than individual ministries in the 
process of budget negotiation with the MoF (Lechevalier et al. 2016). Its secretariat was since its creation placed - like the Council itself - directly under the Cabinet Office and counted between 50 to 60 staff (Harayama, 2001). The number of members also increased as more members coming from the private and academic sectors strengthened its legitimacy. Furthermore, while the CST held plenary meetings where the Prime Minister was present only once or twice a year, from 2011 onwards the CSTP held almost monthly plenary sessions. Substantial discussions between the Prime Minister, the ministers and the executive members took place in these meetings (NAP, 2009). Finally, as previously explained, a key element of CSTP power was its role in coordinating the development of the Basic Plans that set the overall guidance for all ministries on STI policy issues.

However, despite its enhanced power relatively to its predecessor, CSTP still faced headwinds that compromised its ability to fulfil its holistic coordination mandate. In 2011, a review of the 'science and technology innovation strategy headquarters' was undertaken by a group of experts reporting to the State Minister of Science and Technology. It pointed to several strengths and weaknesses of CSTP (Table 3).

\section{Table 3. Strengths and weaknesses of the CSTP identified by a group of experts in 2011}

\begin{tabular}{|c|c|}
\hline Strengths & Weaknesses \\
\hline $\begin{array}{l}\text { - Science and technology policy advisory body chaired by the } \\
\text { - } \quad \text { A rime Minister } \\
\text { expearch and deliberation body consisting of ministers and } \\
\text { Policy Council") } \\
\text { - Make decision based on a wide range of opinions on } \\
\text { - } \quad \text { science and technology, as well as studies and deliberation } \\
\text { the past } 2 \text { years) } \\
\text { - Existence of Minister for Science and Technology Policy } \\
\quad \text { who assists the Prime Minister }\end{array}$ & $\begin{array}{l}\text { - The policies of the CSTP have not been thoroughly } \\
\text { implemented in each ministry. } \\
\text { - CSTP should be involved in resource allocation } \\
\text { - The autonomous universities and PRIs are free to follow or } \\
\text { not the decisions of CSTP } \\
\text { - Unclear division of roles for cross-ministerial coordination } \\
\text { carried out by the Cabinet Office and MEXT } \\
\text { - Weak system for collecting and analyzing information } \\
\text { necessary for investigation and deliberation } \\
\text { Insufficient communication and collaboration with the } \\
\text { - Weademy of science } \\
\text { Weak secretariat to support the Council for Science and } \\
\text { Technology Policy }\end{array}$ \\
\hline
\end{tabular}

Source: Adapted from Cabinet Office (2011)

The holistic coordination function was again strengthened when the CSTI took over from CSTP with a view to make it able to "take powerful actions that are substantially different from what had been taken by government bodies before", For this to happen, CSTI was granted extended prerogatives, notably with regards to STI budget formulation and programme implementation (see supra), Its expected role in cross-ministerial coordination is clearly apparent in its tasks as have been synthetised in the 2014 Comprehensive Strategy (Government of Japan, 2014):

- Grasping the whole picture and cross-cutting functions toward integrated promotion of science and technology and innovation policies

- Inter-ministry policy guidance by utilizing the Science, Technology and Innovation Budgeting Strategy Committee, SIP, and ImPACT, etc.

- Collaboration between headquarters, eliminating the silos between ministries, strengthening the industry-academia-government collaboration, and speeding up the process from basic research to exit

CSTI is particularly active in trying to reduce the gap and communication barriers between MEXT and METI. It can take the initiative of establishing temporary task forces on key transversal issues, for instance on environment matters or natural disasters, where MEXT, 
METI and sectoral ministries are invited to exchange their respective plans and activities to reduce unnecessary overlaps and identify cooperation opportunities.

\subsubsection{Thematic coordination}

\section{Public private coordination in priority sectors}

As previously mentioned, public-private research consortia were a key instrument for coordination between public authorities and private companies in sectors considered for the development of Japanese economy up until the end of the 1980s. During the 1990s, the government shifted toward softer - less interventionist - forms of coordination. It used various soft coordination tools to this end, notably public-private coordination platforms, technological roadmaps and strategies.

The coordination of fuel cell R\&D-related issues is a good example of this new pattern of relationships between METI and private firms. Since the end of the New Sunshine Program, the coordination of fuel cell R\&D activities within a common public-private organisation has been progressively replaced by a new pattern of relationships in which an interactive platform (the FCCJ) led by the private sector with participation of public authorities played an important role (Box 3). 


\section{Box 3. The Fuel Cell Commercialization Conference of Japan (FCCJ)}

The Fuel Cell Commercialization Conference of Japan (FCCJ) was created in 2001 and is still operating in 2020. It is an association of a wide range of private companies and stakeholders that aims at providing guideline for METI technology policy in the fuel-cell area fromorientation of public support R\&D activities to demonstration and deregulation initiatives. Precisely, the role of the FCCJ is to "examine specific issues affecting the commercialization and widespread use of fuel cells, and incorporate the findings into policy proposals with a view to enabling member companies to take steps to resolve the issues themselves, and having these findings reflected in government measures".

With only a few members at the beginning, this original initiative soon gained credibility and legitimacy and became the core of new institutional infrastructure in the fuel cells area. It gathers almost all the Japanese companies originating from diverse industries that are actually involved in fuel cell activities or are considering the opportunity of doing so (about 140 organisations in 2003, 105 in 2020), including the automobile companies. The light and informal status of this organisation made possible such a wide participation. It covers issues from component and system R\&D to demonstration, promotion, regulations and standardization of fuel cells. It also covers various applications of fuel cells, especially fuel cell vehicles and stationary power units.

The result of the dialogues engaged between members in the various groups and sub-groups is synthetised in FCCJ's list of issues to be tackled and corresponding policy recommendations that are delivered to METI each year. It also develop commonly agreed target values for different time horizons as well as standardised method of evaluations for different types of components. The association can also have a more hands-on role in some demonstration programmes.

Although the FCCJ has no formal power, the fact that it gathers almost all the companies connected to fuel cells and cover all aspects of the technology grants the association a relative de-facto power over public authorities. Government officials keep their autonomy of choice but cannot ignore the opinion of a large part of the "fuel cells community".

Although the primary mission of the FCCJ is to facilitate and improve the relationships between private companies and public authorities, it also permits interactions between private companies across sectors. For instance, relevant working-groups hold precise negotiations between energy industries and automobile companies on the establishment of the needed infrastructure.

Over the years, the FCCJ has evolved beyond policy advising: it became rapidly considered as a promising new type of interface between the government and the industry allowing industrygovernment coordination and cross-industry coordination.

One of the limitation of the FCCJ was its exclusive relationship with METI. Although interministry coordination is not essential for issues related with fuel cells R\&D (which almost only concerns METI) it is a major hurdle to deregulation issues that tightly intertwine different ministries and public agencies. Several initiatives were intended to alleviate this issue. During the early 2000 for instance, a working group constituted of the vice-ministers of three ministries related to fuel cell activities (METI, MOE, MLIT) was established in order to define broad guidelines regarding deregulation of the fuel cells area.

\section{Interministerial coordination in specific areas: the sectoral headquarters}

In parallel to the strengthening of the CSTP and, later on, CSTI, the government created several headquarters ${ }^{15}$ under the Cabinet Office and the Cabinet Secretariat with STI interministerial coordination functions in their respective areas. The Strategic Headquarters for the Promotion of an Advanced Information and Telecommunications Network Society (hereafter, the 'IT Strategy Headquarters') was created in 2000, the Intellectual Property 
Strategy Headquarters in 2005, the National Space Policy Secretariat and the National Ocean Policy in 2007. Under the Fifth Basic Plan, in 2013, the Headquarters for Healthcare Policy and the National Security Council were created. All headquarters are chaired by the Prime Minister and vice-chaired by the Chief Cabinet Secretary and several relevant ministers. Members include other ministers and high level (Director-General level) representatives of various administrations. ${ }^{16}$ These bodies are in charge of whole-ofgovernment efforts in their respective areas, starting from the development and holistic implementation of the main STI strategy in these areas. The Headquarter for Healthcare Policy is responsible for the Healthcare Policy, the National Ocean Policy deals with the Basic Plan on Ocean and the National Space Policy Secretariat with the Basic Space Plan. The Intellectual Property Strategy Headquarter is in charge of the Strategic Program on the Creation, Protection and Exploitation of Intellectual Property and, finally, the IT Headquarter is tasked with the development of a priority policy program to form an advanced information and telecommunications network society.

\section{Widening the scope of interministerial coordination: the Integrated Innovation Strategy Promotion Council}

Headquarters therefore take important decisions regarding STI policy interventions in these areas, contributing to the improvement of inter-ministerial coordination, but also runs the risk of overlaps with CSTI. In order to coordinate the functions of CSTI with those of the area-specific headquarters, the Integrated Innovation Strategy Promotion Council was established in 2018. This Council is located under the Cabinet Secretariat and is chaired by the Chief Cabinet Secretary, and composed of several 'Ministers of State for Specific Missions' who act as heads of headquarters and CSTI. ${ }^{17}$ It is in charge of supporting coordination between ministries as well as between 'control towers' closely related to innovation, and developing and promoting the annual Integrated Strategies. ${ }^{18}$ In practice, the CSTI with its secretariat conserves the leadership on drafting of the annual Integrated Strategies. Its supportive staff originates from other departments (including some from CSTI's secretariat). Inputs from expert meetings held on specific topics inform dedicated administrative task forces whose works feed into the deliberations of the Council (Figure 5). ${ }^{19}$ The Council met 3 times in 2018; and twice in 2019 and 2020. 
Figure 5. Overview of the different headquarters and the Integrated Innovation Strategy Promotion Council

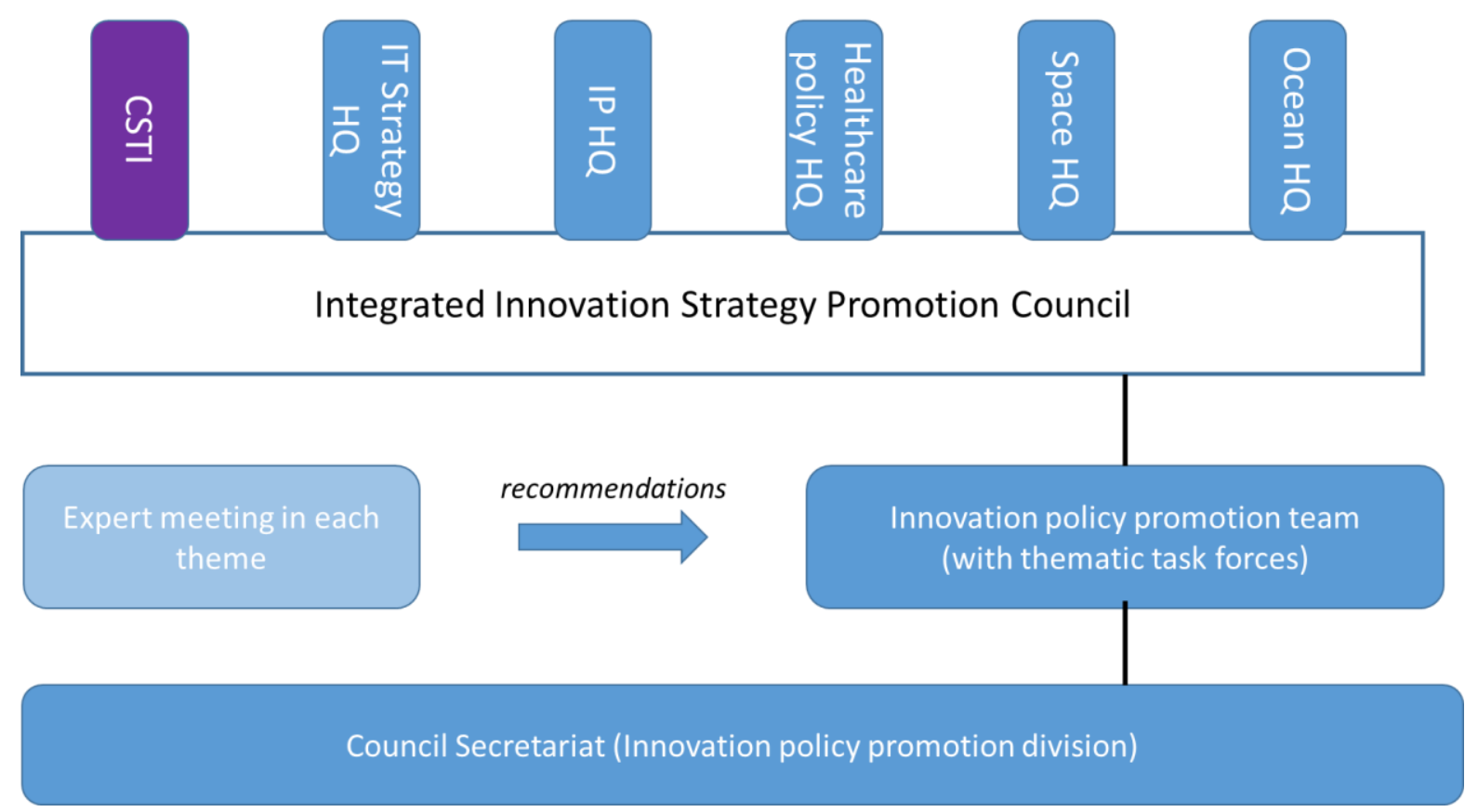

Source: Izumi H. (2019), Japan's innovation strategy and the bioeconomy strategy 2019, document dated October 92019.

Several interviewees have stressed that the multiplication of the Headquarters in areas with strong relevance to STI policy has made the governance of the STI system more complex and burdensome as it increases the number of actors CSTI has to consult and negotiate with. While these headquarters were created - like CSTI - with a view to improve interministerial coordination, the multiplication of such 'control tower' bodies also runs the risk of replacing ministerial silos with headquarters silos. At the very least, the adoption of a governance model where an overarching STI headquarter coexists with area-specific STI headquarters increases significantly the number of interaction channels (see Figure 6). 
Figure 6. Four simplified models of interministerial STI coordination in the Japanese context

Ministerial silos model

MEXT

Overarching STI headquarters model

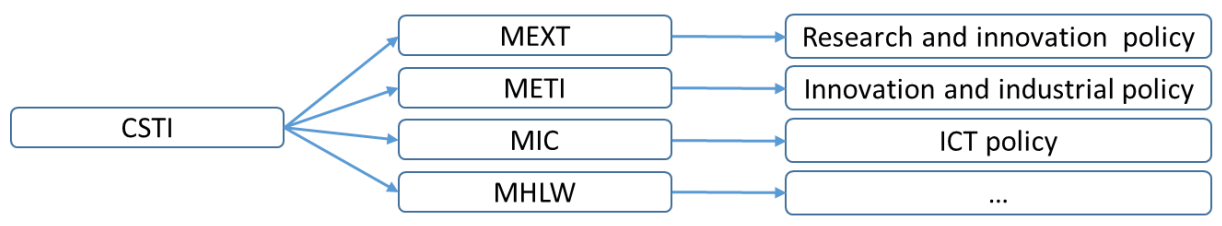

Thematic headquarters model

IP Headquarters

Mixed model model with overarching STI and thematic headquarters

CSTI Research and innovation policy

Note: This is a simplified and modelised view with four headquarters and four ministries only: MEXT: Ministry of Education, Culture, Sports, Science and Technology; METI: Ministry of Economy, Trade and Industry MHLW: Ministry of Health, Labour and Welfare; MIC: Ministry of Internal Affairs and Communications

It has also somewhat blurred the role of CSTI that is no longer the only STI control tower when it comes to dealing with some of the areas of other headquarters. While in most policy fields, a Council is an advising body and a headquarter is closer to a policy implementation body, the direct policy implementation function granted to CSTI makes this distinction less valid in the STI area.

Furthermore, the situation is not identical in all areas since the role of Headquarters depends on when they have been created. In areas covered by these Headquarters, CSTI's intervention has become limited and they have to follow Headquarters' strategic plan. This is compounded by the fact that the new tasks of CSTI regarding the formulation of the STI budgets and the implementation of its own programmes (ImPACT and SIP) are consuming significant resources of its members and its secretariat. According to some interviewees, CSTI has therefore no other choice but to leave the very time-consuming task of interacting with the different ministries to HQs in these areas. Interministerial coordination in these areas is therefore less 'STI-led' since the Headquarters' prerogatives extend beyond STI issues. The establishment of the Integrated Innovation Strategy Promotion Council has somewhat alleviated this issue. 


\subsubsection{STI Budget coordination}

\section{The Science and Technology Budgeting Strategy Committee}

Basic Plans are a key coordination tool. They provide guidance to ministries on the vision to aim for and corresponding priority challenges, fields and initiatives. However, ministries initially remained free to choose whether to follow these strategic guidelines or not, and CSTP had little information to monitor if the ministries' budget plans corresponded to the overarching 5-year plan. When the new majority returned to power in 2012, it became clear that the newly created CSTI could exert the expected level of leadership only if it had a clear and robust overview of how much the different ministries invested in STI activities and in what type of projects. CSTI was therefore granted a new role to collect information from ministries on STI budgets and advise them and MOF on these matters. Prior to this, the budget formation in each policy field was mainly the result of a bilateral relation between the relevant ministries and MOF.

For this newly created function, the Science and Technology Budgeting Strategy Committee was created under CSTP in 2013. It is chaired by the Minister in charge of the science and technology policy and consists of senior officials (Director General level) from the relevant ministries and agencies. The CSTI executive members attend the committee meetings. The Committee was tasked with reviewing the budget plans of all relevant ministries prior to any budget appropriation request, consolidating these budgets to acquire an overall view of the whole-of-government STI budgets and, on this basis, providing these ministries and MOF with advises under the form of the 'resource allocation policy'. The objective of this process was to reduce overlaps, enhance cross-ministerial cooperation and ensure that ministries' plans reflect the national priorities set in the mid-term basic plans and annual action plans. ${ }^{20}$ Another objective, more informal but not less important, was to provide incentives for sectoral ministries to increase the share of their budget resources to $R \& D$ and reach the target of $4 \%$ of total R\&D intensity and $1 \%$ government R\&D intensity. This target was already set in the Second BP but has never been fulfilled. Ministries' project acknowledged as STI by the Budget Committee were in a very favourable position when entering the MOF-led budget assessment.

A process was established to formalise the committee's intervention in the budget cycle from June (request for information) to December (formulation of the final government budget) (Government of Japan, 2014).

This process fully functioned for only three-years due to operational difficulties. The process of budget consolidation required that CSTI members and secretariat examined precisely the budget plans of the different ministries to identify the projects with significant STI content. This necessitated highly technical competencies regarding both the budget mechanics and the substantive content of projects that, even with the support from experts, proved beyond what CSTI and its committee could provide. The rotation of the Cabinet Office staff supporting CSTI compounded this problem. These tasks were also very timeconsuming, which hindered the other activities of the Council. While the process is not officially terminated, the Science and Technology Budgeting Strategy Committee has not met in recent years.

\section{CSTI 'conversion' of STI projects}

CSTI currently retains an advisory role in the budget formation process. It devotes a significant effort to clarification and consolidation of the overall STI budget. A new information and accounting system has been developed with a dedicated classification matrix and the use of Natural Language Analysis to scan through all ministries' budgets 
and identify STI initiatives with less fastidious human intervention. ${ }^{21}$ The resulting 'labellisation/conversion' of some initiatives previously non-accounted for as 'STI' provides a more reliable picture of the effective government effort in innovation, and shows the real distance to the $1 \%$ target. To this end, the ministries provided the necessary information to CSTI since 2018. They are incentivised to do so since CSTI, like it was the case when the Budget Committee was active, 'certifies' the programmes converted to STI and supports them in the central budget assessment process, hence increasing the likelihood of an approval by MOF (Ueyama, 2018). This is of course key to the acceptance of CSTI's role. As it was already noted by Stenberg and Nagano at the time of the CSTP, such practices can only succeed if it offers value to the ministries in return for the CSTI's request for information and intervention: "Merely serving in a support function to the Ministry of Finance in the annual budget negotiations is unlikely to be appreciated. Acceptance of the CSTP would definitely increase if it were proved able to influence the size of the total budget available for $S \& T$ " (Stenberg and Nagano, 2009). While the conditions were not ripe for this to happen in the 2000s, the current priority put on STI by the current government might give this process a better chance. However, whether this 'deal' functions in practice with CSTI is unknown.

\section{PRISM}

PRISM is a new coordination mechanism to encourage ministries to increase their R\&D investment in certain areas considered as national priorities (based on the current annual Integrated Strategy) and where it is expected that additional government funds would have a strong leverage effect on private $R \& D$ expenditures. It basically functions as a budgetary 'top-up' allocated to ministries that agree on creating new initiatives in these areas. Under the supervision of CSTI, a new committee was established under the name of 'Science and Technology Innovation Public-Private Investment Expansion Promotion Target Area Study Committee'. After consultation of private sector representatives, this committee set three target areas in 2017 with strong relevance to the Society 5.0 vision. They are revised and became four target areas in 2020:

- AI technologies

- Construction and infrastructure maintenance technologies / Natural disaster prevention and disaster reduction technologies

- Biotechnology

- Quantum technologies

This initiative has been allocated a budget of 10 billion yen per year since 2018 (about Euro $82 \mathrm{~m}$ ). It is supervised by the Governing Board for Public-Private R\&D Investment Expansion Program. The Board is in charge of reviewing the targeted measures submitted by ministries, allocating of promotion budget to these targeted measures, monitoring the progress of these measures and, on this basis, implementing annual evaluation conducted by several supervisors. In 2018, CSTI merged the PRISM and SIP Governing Boards in order to coordinate the two programmes more effectively. In addition to the Governing Board, there are also steering committees for each of the four target areas, with a dedicated 'area supervisor'.

According to interviews, this mechanism has had only mixed results so far. The incentives effect seems to work best for ministries with limited R\&D budget (e.g. MAFF). For other ministries, the additional budget might be not significant enough to justify a change of their own plans. Furthermore, as shown in the 2018 Integrated Strategy and various Cabinet Office documents, this initiative functions in close combination with the SIP to the extent 
it became difficult to distinguish one from the other, and PRISM became to some extent diluted in the broader SIP programme. PRISM is therefore facing some difficulties and the four PRISM sub committees (dedicated to each of the four target areas) rarely held meetings in 2019.

It is interesting to note that this new initiative has followed similar attempts in the past. A Special Coordination Funds for Promoting S\&T (SCF) was established as early as 1979. The basic idea of the SCF was to fund high-priority activities which could not be effectively dealt with by individual ministries or which require significant cooperation between sectors (companies, universities, government research institutes) (Stenberg and Nagano, 2009).

\subsection{STI Policy implementation}

\subsubsection{The current science, technology and innovation policy mix in Japan}

As in many countries, the Japanese government has significantly increased its support to STI activities in the two last decades, with a growing emphasis put on basic science in the 1990s and, progressively, on science-industry relationships and entrepreneurial innovation activities. R\&D has become a higher national priority overtime- to the point that Japan is currently among the countries that allocate the highest share of their government resources to R\&D support (Figure 7).

Figure 7. Government budget allocations to R\&D (GBARD), (2019 and 2013)

Percentage of general government expenditures

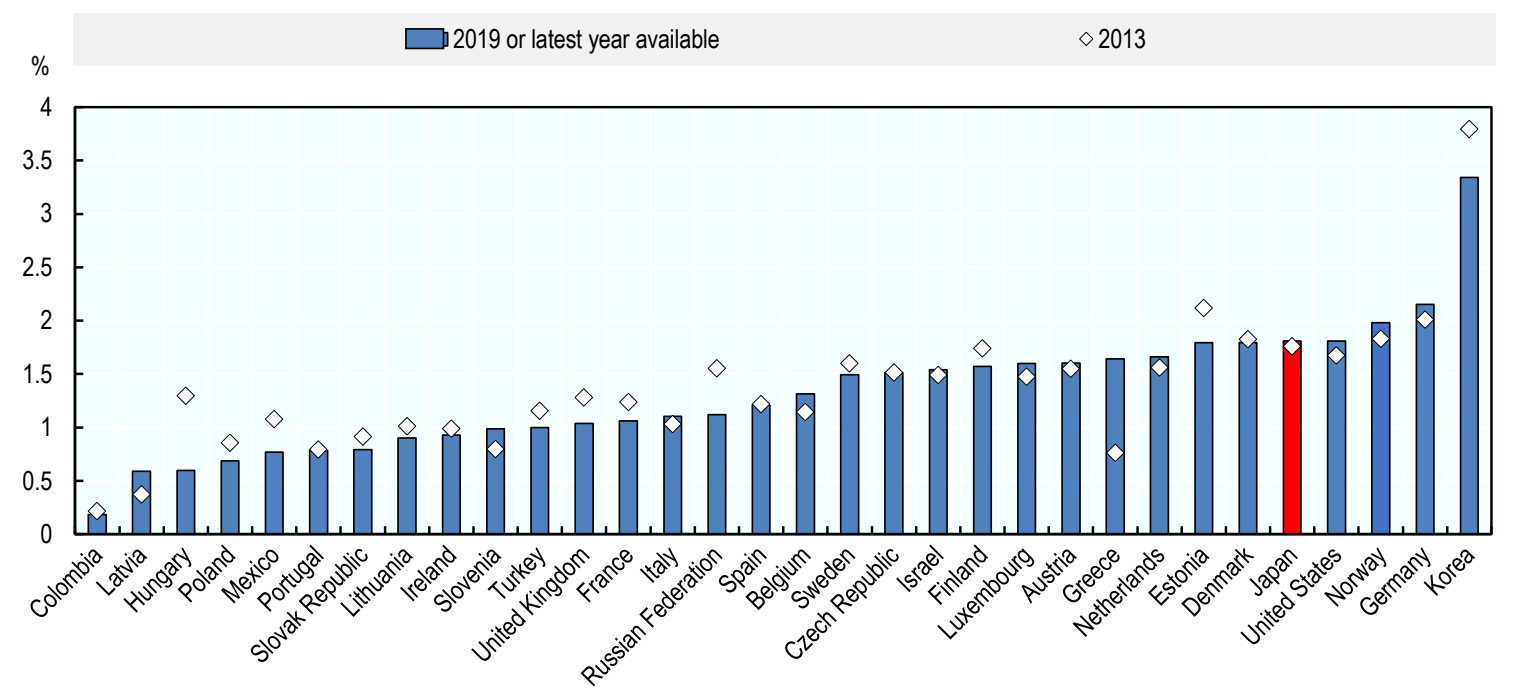

Sources: "Calculations based on OECD, "'Research and Development Statistics: Gross domestic expenditure on R-D by sector of performance and socio-economic objective"", OECD Science, Technology and R\&D Statistics (database), https://doi.org/10.1787/data-00188-en and OECD, "'National Accounts Statistics, Government deficit/surplus, revenue, expenditure and main aggregates"'" https://doi.org/10.1787/na-data-en (accessed on 25 January 2021).

Japan is today amongst the world's largest investors in science and innovation, spending $3.3 \%$ of GDP on R\&D in 2018 (to be compared with an OECD average of $2.4 \%$ and a R\&D intensity of $4.5 \%$ in Korea) (see Figure 8 ). 
Figure 8. Gross domestic spending on R\&D (GERD) (2018 and 2013)

\section{Percentage of GDP}

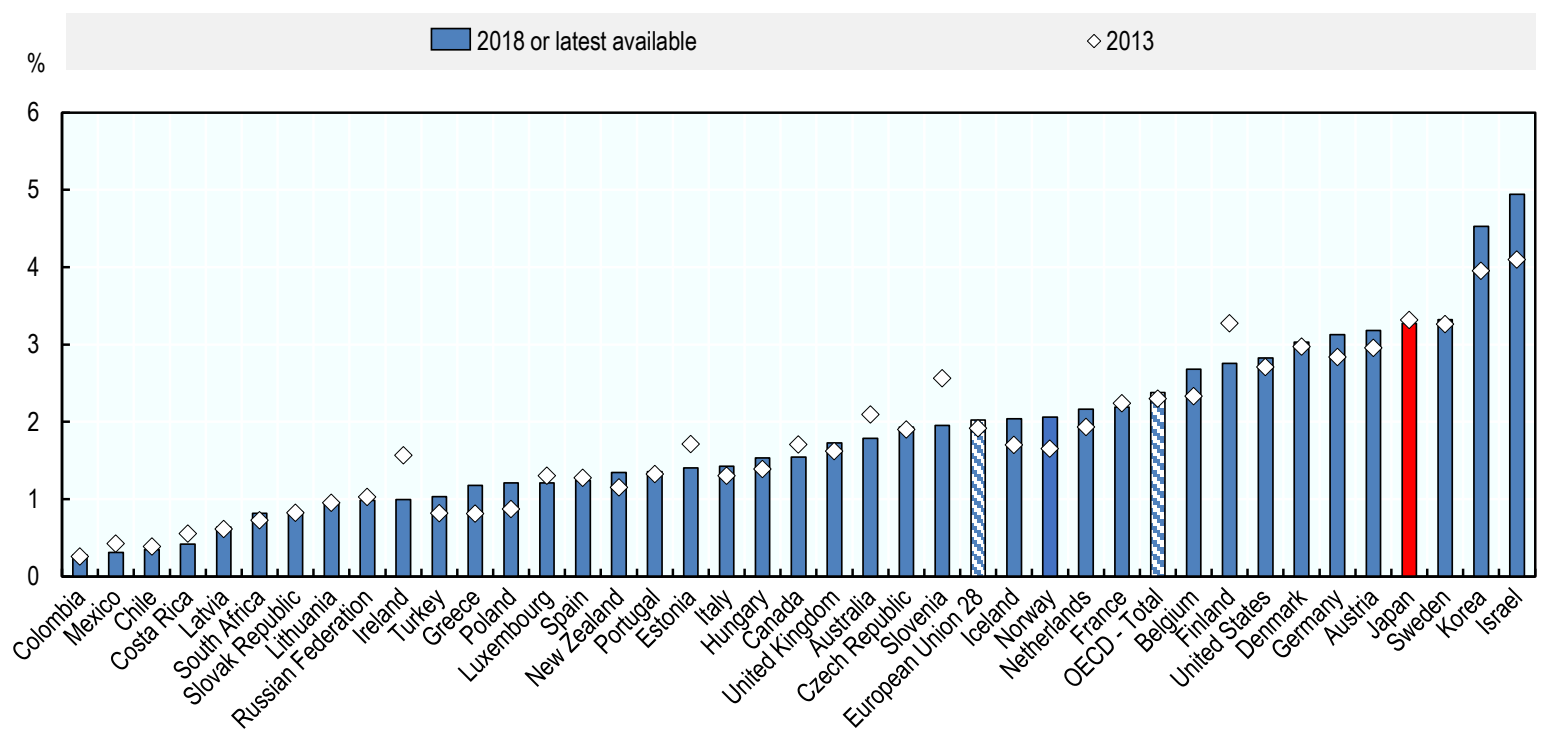

Source: OECD (2021), "Main Science and Technology Indicators", OECD Science, Technology and R\&D Statistics (database), https://doi.org/10.1787/data-00182-en (accessed on 25 January 2021).

However, when considering R\&D expenditures only, it is one of the countries where the share of the government in the funding of these expenditures is the lowest (Figure 9). The level of government intervention in favour of business R\&D as a share of GDP is particularly low (and remained almost stable between 2006 and 2017).

Figure 9. GERD, financed by government (2013 and 2018 or latest)

\section{Percentage of GDP}



Source OECD (2021), "Main Science and Technology Indicators", OECD Science, Technology and R\&D Statistics (database), https://doi.org/10.1787/data-00182-en (accessed on 25 January 2021).

In line with the previous indicators, the government-financed R\&D as a share of the GDP in Japan is low in international comparison. It was $0.59 \%$ in $2016,{ }^{22}$ below the EU-28 $(0.65 \%)$, the USA $(0.69 \%)$, France $(0.79 \%)$, Germany $(0.84 \%)$ and Korea $(0.96 \%)$, but 
above the UK (0.47\%) and China (0.42\%) (MEXT, 2020). As previously mentioned, Japan has set a target of $1 \%$ for governmental R\&D investment as a share of GDP.

This might indicate that the support to STI activities is a policy priority, relatively to other state intervention area, but that this support still represents a minor part of the total R\&D expenditures that are dominated by the investment of large companies. One challenge for Japan since it reached the technological frontier is that the Japanese industry is very R\&D intensive and innovation still relies to a great extent on large corporations in hightechnology sectors that can be reluctant to engage in government-led programmes. While they engaged in pre-competitive research consortia until the late 1980s, it became increasingly difficult to leverage private $R \& D$ resources afterwards. Large industry leaders organised in 'networks' with solid financial systems became less dependent on public subsidies.

A significant portion of the government appropriations dedicated to R\&D in Japan is considered as thematically oriented in international comparison (Figure 10). Non-oriented research includes both research for the general advancement of knowledge and institutional funding. Oriented research includes the research reported by national authorities as contributing to specific socio-economic objectives. In Japan, the public funds for oriented research account for $80 \%$ of the total (direct) fund for R\&D ( $76 \%$ in Korea, $86 \%$ in Norway, $87 \%$ in Austria).

Figure 10. Oriented and non-oriented government R\&D budget (2019 or latest year available) As a percentage of total GBARD

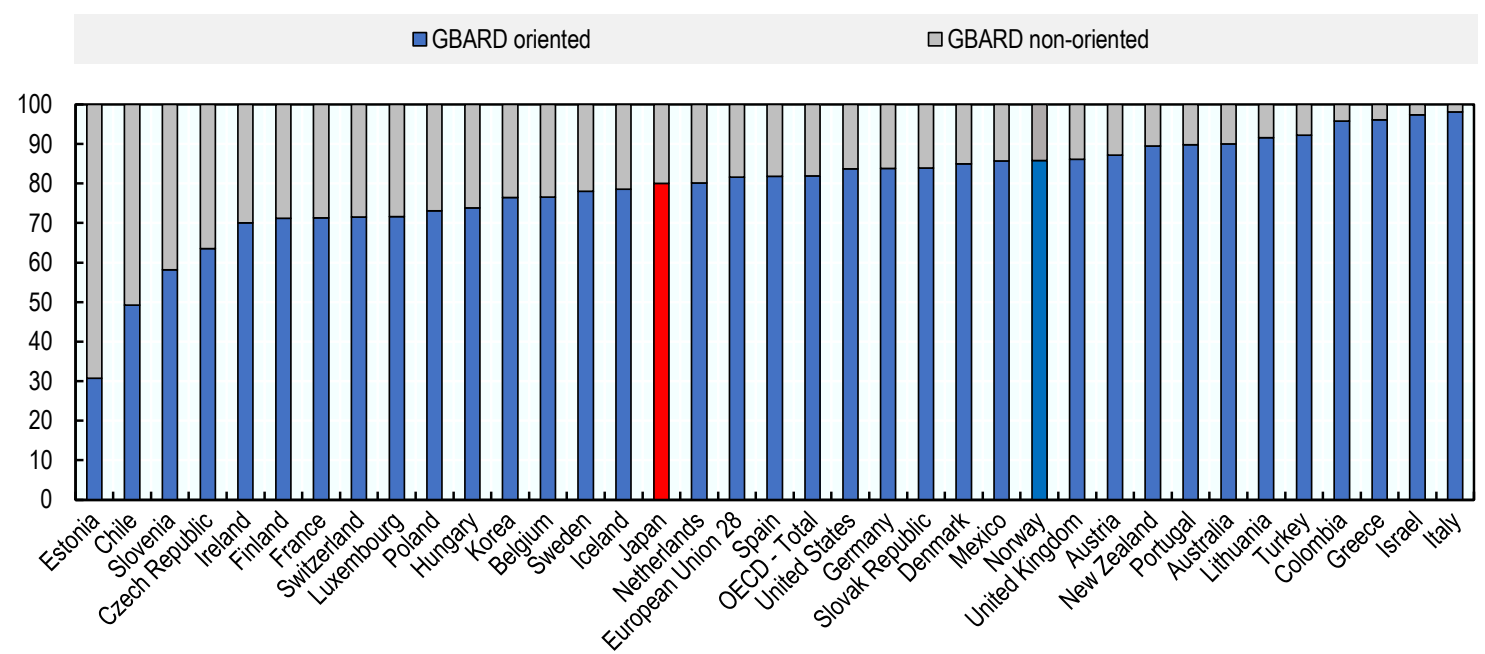

Source: OECD (2021), "Main Science and Technology Indicators", OECD Science, Technology and R\&D Statistics (database), https://doi.org/10.1787/data-00182-en (accessed on 28 January 2021).

Moreover, the share of direct intervention, which allows public authorities to strategically orientate the supported activities in business companies, is low compared to the levels in most of Japan's competitors (Figure 11). The bulk of support to private industry R\&D is distributed via R\&D tax credits, which in 2017 accounted for $84 \%$ of the total government support to business R\&D, up from 71\% in 2011 (OECD, 2019c) (Figure 12). 
Figure 11. Direct and indirect government support to business R\&D, 2018 and 2006

\section{As a percentage of GDP}



Source: OECD R\&D Tax Incentives Database, http://oe.cd/rdtax, December 2020.

Figure 12: Direct government funding of business R\&D and tax incentives for R\&D, Japan, 2000-18 As a percentage of GDP (left-hand scale) and in 2010 prices (Right-hand scale)

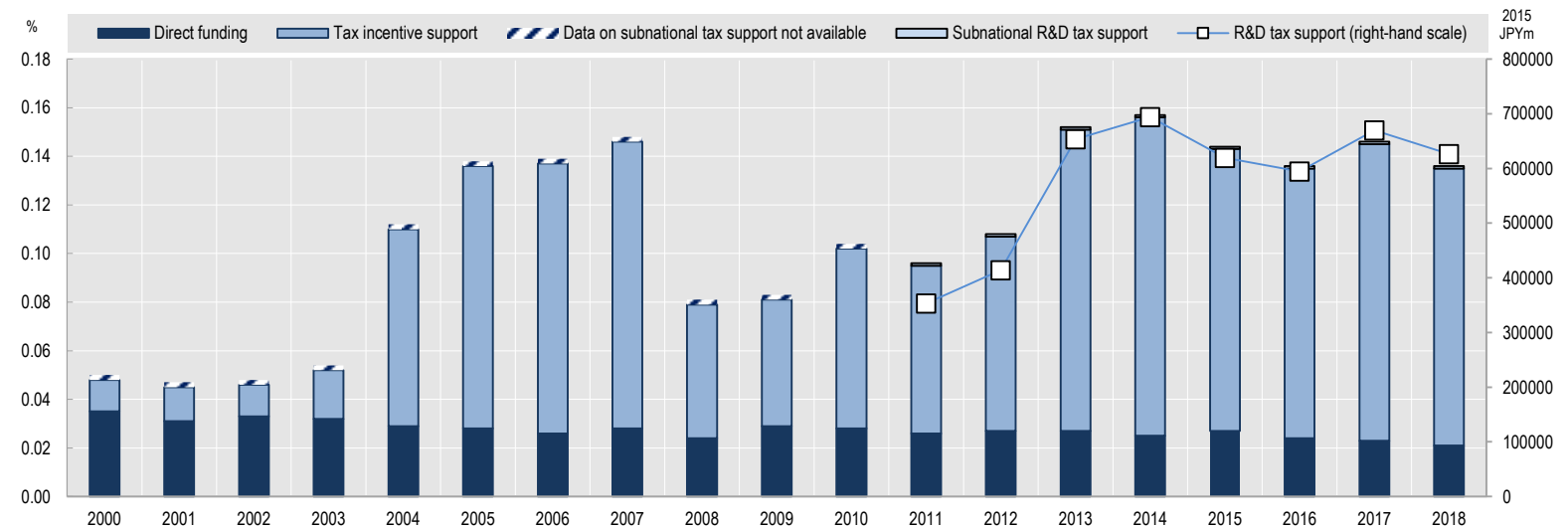

Source: OECD R\&D Tax Incentive Database, http://oe.cd/rdtax, December 2020.

The type of policy instruments used to support public research has also changed significantly. Although a large proportion of public R\&D funding is still allocated to universities via block funding, it has sensibly decreased in recent years. Universities are now more independent from MEXT and rely to a greater extent on competitive grants funding to orientate and support their activities.

Against this backdrop, the large national research institutes such as RIKEN, the National Institute of Materials Science (NIMS) and the National Institute of Advanced Industrial Science and Technology (AIST) are important levers for the government to steer STI activities in priority areas. 
More recently, new top-down 'mission-oriented' strategic programmes led by the Cabinet Office aim to increase universities, research institutes' contribution to some selected national priorities in close collaboration with industry. The Cross-ministerial Strategic Innovation Promotion Program (SIP) since 2014 and the Moonshot Research and Development Program (Moonshot) since 2018 represent two types of mission-oriented policies. The former aims to provide cross-ministerial support to accelerate innovation while the latter is a challenge-based R\&D programme that aims to solve highly ambitious social issues. The two share commonalities in that they both focus on commonly established priorities and are inspired by DARPA's model of programme management that grants extended power to selected PDs in each theme or challenge. The ImPACT programme launched in 2014 to promote high-risk high-reward research also has some MOIP features.

\subsubsection{A new role for CSTI: hands-on involvement in policy implementation}

Following the 2012 elections, the new government tried to reinforce significantly the power of the CSTI vis-a-vis the individual ministries and agencies in order to promote more effectively research and innovation activities to address societal challenges and contribute to the national economy recovery. Despite extended prerogatives, the CSTI still faced difficulties to coordinate actions across ministries. It was therefore decided to take a major step forward by providing CSTI with a large budget to operate its own STI programmes, rather than only trying to coordinate ministries' programmes.

This raised lively debates from different parts of the policy sphere. MOF was rather reluctant, not only for budgetary reasons but also for a matter of 'good governance' since the Cabinet Office's role is to supervise, not to implement, programmes. The mix of these two roles could, according to some officials at MOF, make the governance of the whole system more complex by challenging the established division of labour between coordination bodies on the one side and policy implementation bodies on the other. This situation could also create conflicts of interest if the Cabinet Office was tempted to coordinate ministries in a way that somewhat favours 'its' programmes, or simply overlook its holistic coordination role to focus its resources on programme implementation. Some sectoral ministries also raised objections since these new programmes could reduce the budgets of their interventions and would represent a loss of power on their side. Strong support from some high-level politicians and policy makers of the new government led by ABE Shinzo - who wanted a more top-down STI policy with a stronger role for CSTI helped these programmes become a reality in the end. In order to avoid problems and reassure the sectoral ministries, it was decided that CSTI would only undertake activities that are out of the scope and capacity of individual ministries. It became responsible for the design and implementation of the Cross-ministerial Strategic Innovation Promotion Program (SIP) and was actively involved in a series of two challenge-based initiatives, ImPACT and, more recently, the Moonshot R\&D Programme. 


\section{Mission-oriented policy initiatives in practice}

\subsection{The Cross-ministerial Strategic Innovation Promotion Program (SIP)}

The SIP is a large multiannual national STI initiative created in 2014 to promote research, innovation and demonstration activities in an integrated way. It aims to both address societal challenges and foster economic growth, in areas where strong interministerial coordination is needed. Interministeriality is seen as a way to implement continuous - endto-end - activities from laboratories to early application, and better connect research and innovation activities with the social demand and sectoral context. Although some of the SIP programmes are more long term and science-based than others, the SIP is meant to essentially supports incremental innovation ${ }^{23}$.

The SIP is composed of individual programmes with their own strategic plan (the R\&D Plan) and structure of governance, all under the supervision of CSTI. Each SIP programme is led by an experienced and powerful Programme Director (PD), supported by staff from the Cabinet Office.

The SIP has a 5-year duration, and it was already renewed once in 2018 with a new set of SIP programmes. It benefited from a significant budget of Yen 32.5bn (Euro 266m) per year during its first term from 2014 to 2017 . The overall annual budget was reduced to 28 bn (Euro 229m) in 2018. Individual SIP programmes receive between Yen 1.5bn (Euro $12 \mathrm{~m}$ ) and 4bn (Euro $33 \mathrm{~m}$ ) per year. The SIP budget originates from a 4\% 'haircut' on the STI budgets of all participating ministries.

The Figure 13 provides a synthetic view of SIP. 


\section{2 | MISSION-ORIENTED INNOVATION POLICY IN JAPAN}

Figure 13. Overview of the process, governance and main MOIP features of the Cross-ministerial Strategic Innovation Promotion Program
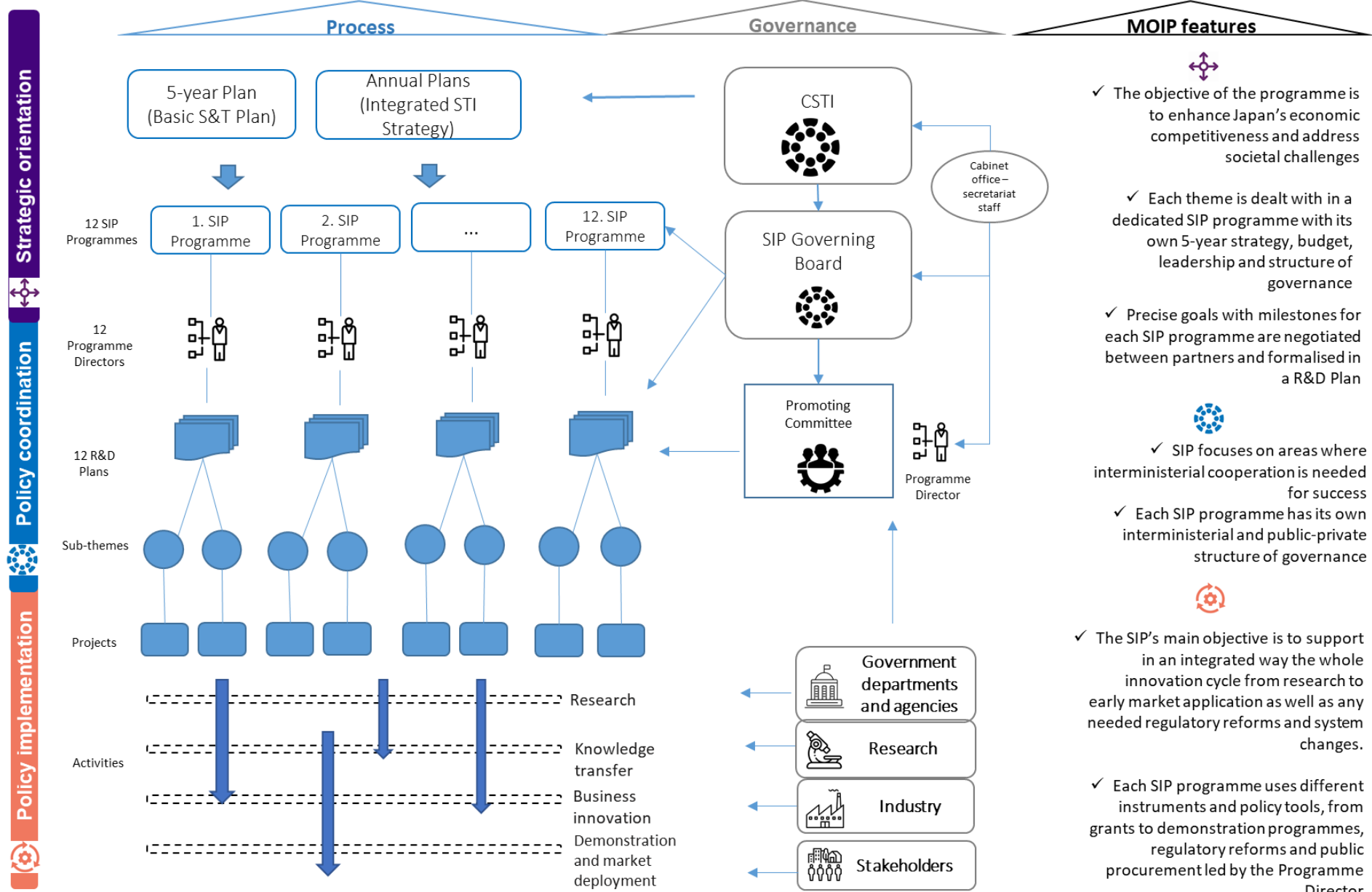

Source: MOIP online toolkit, https://stip.oecd.org/stip/moip 


\subsubsection{Strategic orientation}

The first term that started in 2014 and ended in 2018 was composed of 11 SIP programmes. The second term started in 2018 earlier than planned under strong demand from industry to avoid any discontinuation. It is structured around 12 individual programmes (see Annex B). The initial SIP programmes originated from dedicated expert working groups established to discuss the priorities to be addressed in each of the 5 societal challenges identified in the first Comprehensive Strategy. ${ }^{24}$ These discussions resulted in a list of 10 themes that became the 10 programmes of the first phase of the SIP (one was added in 2016). These themes were then discussed in public workshops and made available on an electronic platform for public comments.

While the objectives of each individual were initially defined in broad terms to gather a broad community of partners from research and academia, more precise goals were later negotiated and formalised into each programme's R\&D Plan. The drafting of the R\&D Plan in each SIP programme is supervised by the PD and validated by the SIP overall Governing Board. It is one of the distinctive features of the SIP that the PD is recruited first on the basis of its technical and management skills; the development of the programme R\&D Plan is led by the PD a few months after.

R\&D Plans present systematically different types of goals: Social Goals, Industrial Goals, Technical Goals, Institutional Goals. R\&D Plans follow the same structure but the nature of goals vary sensibly across programmes. Some programmes have set precise and measurable goals with clear milestones. For instance, the second term R\&D Plan of the Programme on 'Automated Driving for Universal Services' (SIP-adus) has set the objectives of achieving high driving automation (SAE Level 4) ${ }^{25}$ on highways around 2025 or later for privately owned vehicles and trucks. The SIP Programme on the 'Development of Innovative Technologies for Exploration of Deep Sea Resources' aims to improve survey speed 30 times faster than that of current technology, developing the world's most advanced survey system in areas shallower than $6,000 \mathrm{~m}$ below sea level and transfer the technologies to industries. ${ }^{26}$ Other SIP programme objectives remain very scientific or technical.

The SIP is therefore very directional due to precise R\&D Plans that set objectives and timetables for the programme and all of its subcomponents. Each programme is therefore guided by a dedicated 5-year 'roadmap' and is binding to the project partners. It is however flexible since the R\&D Plan can be revised if needed each year based on the results of the annual evaluation process. Another strong element of directionality is the strong leadership of the PD. Each PD has been selected either from the industry or academia for their proven leadership and expertise on the specific topic of their programme. They are appointed as executive government officers in the Cabinet Office, which participates to reinforce their leadership. PDs organise and promote an R\&D plan in their respective programme. They have the power to organise R\&D teams and to make open calls or initiate activities as needed. PDs also have the power to decide on the allocation of budgets to implement the R\&D Plan. The PD has therefore strong prerogatives in terms of each programme's orientation as long as it complies with the broad SIP objectives and principles established by the Governing Board.

While highly 'directional', SIP has several built-in mechanisms to make it more flexible. Each programme's R\&D Plan can be adjusted during the course of the programme if needed, based on the results of the evaluations and self-assessments carried out annually. The allocation of the budget by the Cabinet Office following an annual decision of CSTI is also more flexible than it would be in the traditional case where a ministry negotiates its programme bilaterally with the Ministry of Finance. Finally, another factor of flexibility 
resides in the decision power of the PD who has substantial freedom to initiate and fund a range of activities within the scope of the allocated budget (including without open calls if there are rationales for this).

\subsubsection{Policy coordination}

The SIP programme is - as its name suggests - interministerial by design. This key feature of the programme is implemented at overall SIP and individual programme levels.

At overall level, the programme is led and managed by the CSTI whose primary function is to ensure the holistic coordination of STI policies across ministries and agencies. CSTI has selected the SIP programmes and the PDs, and validates the decision of the SIP Governing Board. The SIP Governing Board, composed of CSTI executive members (i.e. not including the Prime Minister and policy makers), meets about 20 times every year to ensure the overall coherence of the entire SIP programme. With support from technical experts, the Board notably approves the individual programmes' R\&D Plans developed by the $\mathrm{PD}$ and is in charge of the annual evaluation of each programme.

At individual programme level, the Promotion Committee is chaired by a PD and consists of sub-directors (assisting the PD in sub-themes), relevant ministries, related government agencies and experts on the topic. The main role of this committee is to discuss and monitor the execution of the R\&D Plan and coordinate any issue related to the implementation of the program. Several SIP programmes have also set up Working Group under the Promotion Committee in order to discuss in more details some topics.

The PD who chairs the Promotion Committee is also considered essential for the promotion and smooth operation of interministerial coordination and science-industry cooperation. Furthermore, the degree of interministerial coordination is one of the criteria for evaluation of individual SIP programmes.

Figure 14. Generic governance structure of the SIP and one SIP individual programme

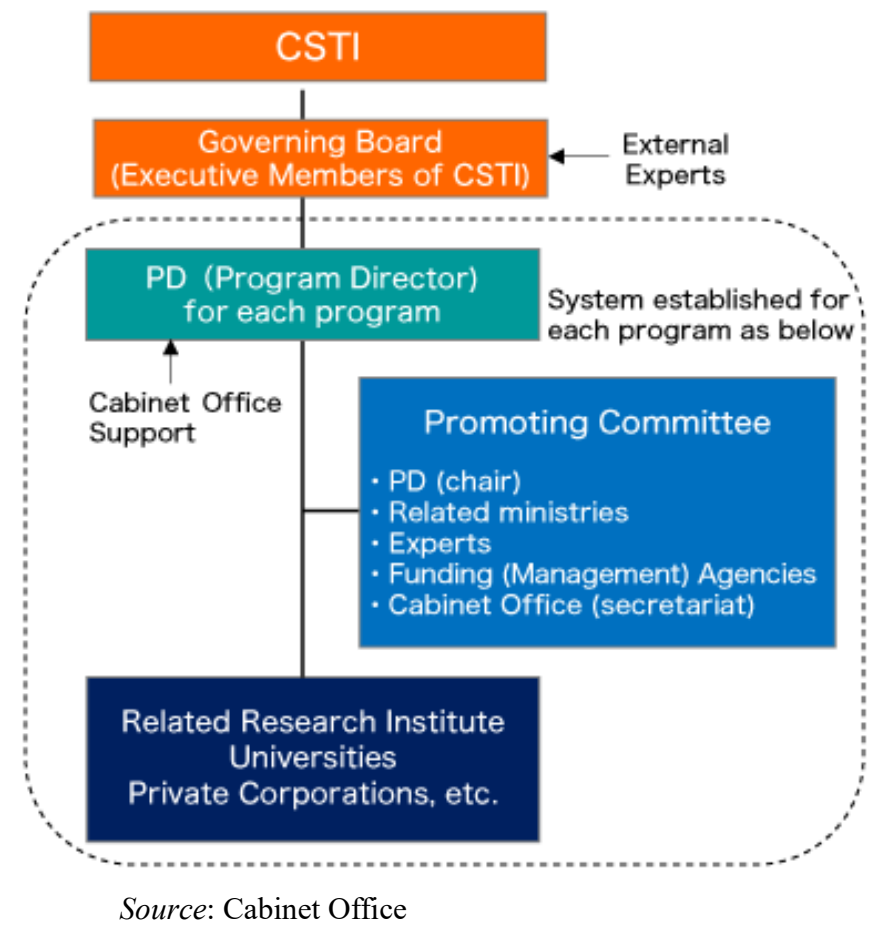




\subsubsection{Policy implementation}

Each SIP programme uses different instruments and policy tools from grants to demonstration programmes, regulatory reforms, standardisation and, in few cases, public procurement. The mix of instruments is fine-tuned by the PD in order to achieve the objectives of the R\&D Plan and negotiated with the policy-making bodies that participate in the Promotion Committee. It also depends on the SIP programme's funding agency that take charge of the practical administration and funding of the programme activities. The funding agency also deals with the expenditure management and IP support.

The SIP focuses - at least in theory - on innovation, not on the advancement of general knowledge or the achievement of technological breakthroughs. All R\&D Plans include 'exit strategies', 'deployment milestones' or a 'commercialisation strategy'. However, some SIP programmes are more science-based and the commercialisation / exploitation of the results is in these cases planned beyond the 5-year term of the programme or even its successor. The renewal of the SIP for the second term was the occasion for the Cabinet Office to reaffirm the priority given to innovation and that the SIP is not meant to only support basic research projects in universities or even applied research in national research institutes. Science-industry cooperation is expected to be at the core of each SIP programme.

Beside a few very science-based SIP programmes in the first phase, business companies (and users in general) are key partners or even leaders in almost all programmes. PDs who originate from industry in about half of the SIP programmes undertake an important role to inquire on needs and ensure the connection with the demand-side. The SIP Programme 'Big-data and AI-enabled Cyberspace Technologies' for instance aims to encourage programme partners to create new services and businesses in areas where collaboration between human and AI is considered effective (Nursing care, education, customer service, etc.). To do so, end-users (including companies) participate in programme activities from the initial stage of development. Developers and diverse users also conduct demonstration and experiments using the $R \& D$ results.

More generally, the SIP programme has been praised by private companies and industry associations (notably the Japan Business Federation 'Keidanren') for the simplicity of participation in the programme, its flexibility and focus on innovation. This attractiveness of SIP for the private sector shows in the structure of leadership of the SIP programmes that are less science-oriented. This is for instance the case of the SIP programme "Technologies for Smart Bio-industry and Agriculture", where the PD and two of the subPDs are from industry (out of 3), as well as 3 Strategy Coordinators (out of 6).

The attractiveness of the SIP for industry might also find its roots in its flexible funding arrangement. In the first phase, it was not compulsory that industry partners contribute financially to the programme. In the end the extent of the industry contribution varies significantly between programmes, depending on whether they are more or less industrybased. In the second term SIP programme on 'Automated Driving for Universal Services' (SIP-adus), the 2019 R\&D Plan stipulates that contributions from the business sector for the entire programme period (i.e. 5 years) including both in-kind and financial contributions are expected to exceed $1 / 3$ of the programme budget (i.e. the total of contributions from both the national government and the business sector). In a more science-based programme like the one on 'Research and Development Plan on Innovative Technologies for Exploration of Deep Sea Resources' future contributions from industry are expected to reach only about $3 \%$ of the total $R \& D$ expenditures during the course of the programme.

Another important aspect of the SIP - one that was also a characteristic of the former research consortia - is that it serves as a 'forum' that can host negotiations between 
competitors to fine-tune the rules and scope of cooperation. Some SIP programmes have clearly formalised the frontier between the issues and areas that can be dealt with cooperatively and those that must remain competitive. In the SIP-adus programme for instance, while the issues related to telecommunication technologies and the mapping for automated driving fall into the cooperative area, the $R \& D$ on sensors remain in the competitive area of the programme where special rules apply to protect information on activities.

The SIP Programme as a whole is subject to ex ante and ex post evaluations and the SIP individual programmes are subject to ex ante, ex post and annual evaluations, with several steps of self-assessment and peer reviews by specialists. The results of these evaluations are then reflected in the allocation of the budget in the following year and can lead to significant change in the programme $R \& D$ Plan, governance or management. The $R \& D$ Plans of each programme are also reviewed in the light of the progress accomplished and are revised if necessary, following agreement by the Programme Promotion Committee and validation by the SIP Governing Board.

\subsection{ImPACT}

The ImPACT programme was created in 2014 at about the same time of the SIP in order to generate disruptive innovation. Its total budget was about Yen 55bn (about Euro 450m). It ended in 2019. It took over from a former programme, the 'Funding Program for WorldLeading Innovative R\&D on Science and Technology' programme (FIRST Program) (Box 4).

The Figure 15 provides a synthetic view of imPACT. 
Figure 15. Overview of the process, governance and main MOIP features of the ImPACT Programme

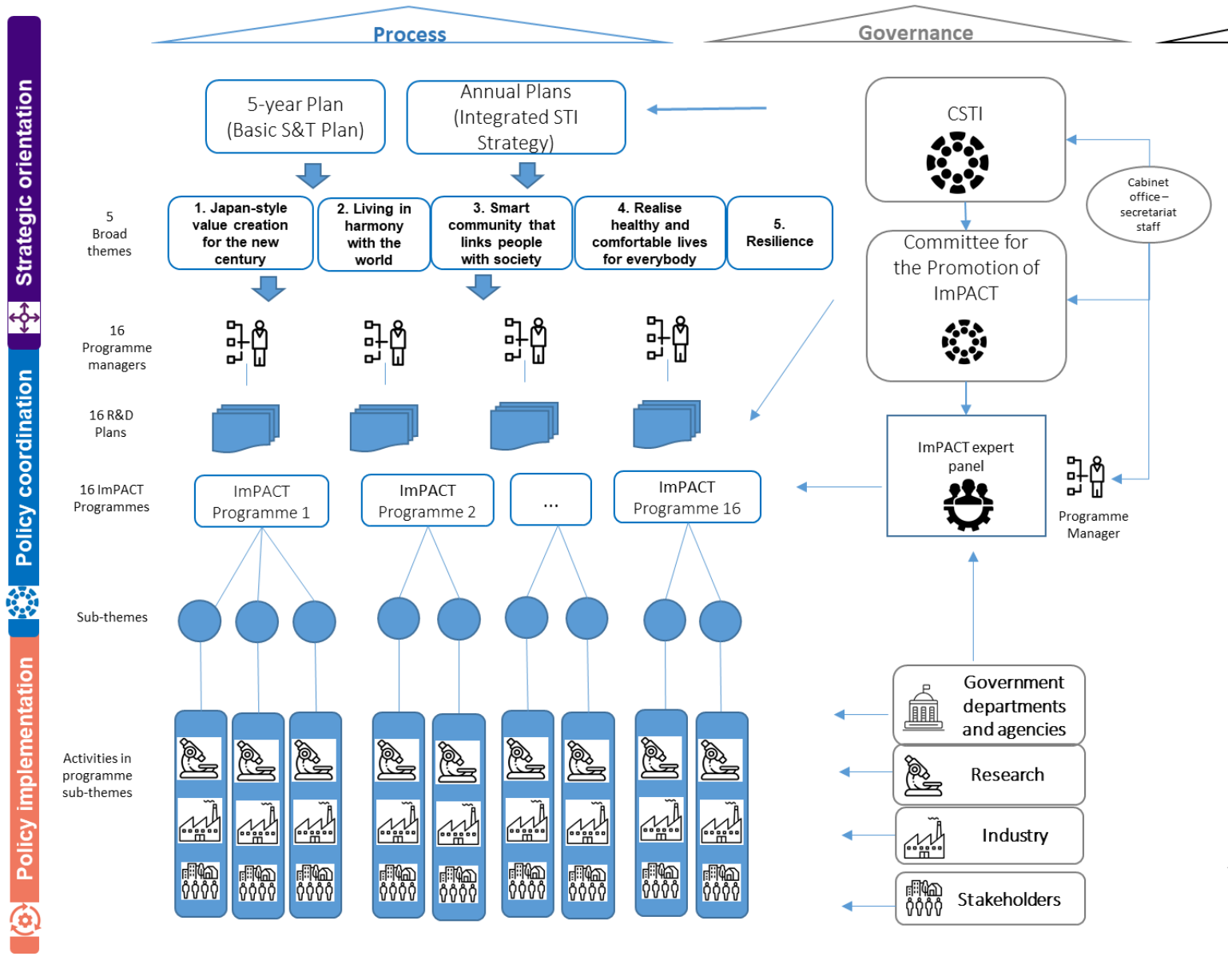

MOIP features

$\leftrightarrow$

$\checkmark$ The objective of the programme is to promote high-risk high-reward research in 5 broad themes where disruptive innovations could overcome important societal challenges
Selection of the programme concept, then development of fullyfledged R\&D Programme by each PM a few months after the selection

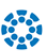

$\checkmark$ Interministerial via the CSTI and the Committee for the Promotion of ImPACT, in which seat different policy bodies R\&D Programmes are designed using a backcasting approach to ensure the
articulation with demands and needs

(t)

$\checkmark$ Financed through a multiannual fund, which provides PMs with more flexibility to conduct their projects and adapt to changes and progress

$\checkmark$ PMs are granted significant authority to leave them freedom as regards the use of the funds and management of the project (DARPA's model)
(DAR thect

PMs assemble their own dedicated team to ensure the success of their project $\checkmark$ 'Light' supervision that respects the

Source: MOIP online toolkit, https://stip.oecd.org/stip/moip

OECD SCIENCE, TECHNOLOGY AND INDUSTRY POLICY PAPERS 


\section{Box 4. The FIRST Programme}

The 'Funding Program for World-Leading Innovative R\&D on Science and Technology' programme (FIRST Program) was launched in 2009 to support progress of cutting-edge research projects in a strategic and comprehensive way. The main characteristic of this programme was that it did not select and fund research projects but researchers. The selection was made by CSTP, following a review of proposals and an initial selection by dedicated programme expert groups. In the end a total of Yen 100bn (about Euro 815 million) was allocated to 30 projects in 2009 (see Annex C). The programme was mainly excellence-based - without strong strategic orientations - and was not particularly cross-ministerial since it focused on upstream research. However, it allowed testing some unique mission-oriented features that would be important in the ImPACT and SIP programmes:

- Authority and freedom granted to a core person - while the FIRST selected researchers are selected primarily for their research excellence, hence not in line with a typical DARPA programme manager, they are placed at core of the projects and granted extended power to conduct their projects.

- Flexibility - Multi-year research funding providing more flexibility to research programmes. Those traditionally funded by Ministries are hindered by Japan's singleyear budgetary system that does not allow carrying over remaining budgets into the next fiscal year. The FIRST programme's funding resources were available through a dedicated Fund which allowed their multi-year usage of the financial resources.

- Effective implementation - the selected researchers could choose the operational support institution for their projects. Traditionally, researchers have no other choice than their affiliated institution. Giving the choice of the implementation agency to the researcher allows them to make optimal use of their abilities in advancing their $\mathrm{R} \& \mathrm{D}$ projects.

- Mixed instruments and funding - FIRST allowed the combination of mixed funds from various sources to support the same projects.

The FIRST programme was positively evaluated in 2013 under the supervision of the CSTI.

\subsubsection{Strategic orientation}

The ImPACT programme aims to promote high-risk high-reward research in 5 broad themes where disruptive innovations could bring quantum advances to the Japanese industry and overcome important societal challenges (CSTP, 2014a):

- Release from constraints on resources and innovation in "monozukuri (manufacturing)" capabilities (Japan-style value creation for the new century)

- Realisation of an ecologically sound society and innovative energy conservation that changes lifestyles (Living in harmony with the world)

- Realisation of a society of highly advanced functionality that surpasses the information networked society (Smart community that links people with society)

- Provide the world's most comfortable living environment in a society with a declining Birth rate and ageing population (Realise healthy and comfortable lives for everybody) 
- Control the impact and minimise the damage from hazards and natural disasters that are beyond human knowing (Realise a resilience that is keenly felt by very individual Japanese)

The first step consisted in the selection of $12 \mathrm{PMs}$ who had promising ideas for addressing the 5 themes prioritised by the CSTP. In 2015, 4 programme managers were additionally selected. The selection was made by the CSTP based on a review of applications by the Committee for the Promotion of ImPACT and the ImPACT expert panel. The main selection criteria for the PM go far beyond his knowledge in the field to include the understanding of commercialisation aspects, ability to communicate, motivation for high impact innovation; as well as a short outline of the underlying project (less than 10 pages). Once selected on this basis, the PM had a few months to develop a fully-fledged R\&D Programme. During this period, the PM was expected to undertake various consultation activities (workshops, idea contests, etc.) to collect views from various actors in different sectors and communities, not least among users. One key requirement was that the R\&D Programme be designed using a backcasting approach, i.e. starting from the 'exit'. The PM also had the power to revise the R\&D Programme as needed.

\subsubsection{Policy coordination}

Like SIP, ImPACT is supervised by CSTI and the Committee for the Promotion of ImPACT headed by Minister of State for Science and Technology Policy and composed of the Senior Vice-Minister for Science and Technology Policy, the Parliamentary Secretary for Science and Technology Policy, and the CSTP executive members. This Committee is the body that takes all the highest level decisions, based on review and preselection by the ImPACT expert panel. The latter was composed of the CSTP executive members, supported with external experts mobilised on a need basis depending on the tasks or topics to be discussed (for instance the review and selection of the PM candidates; the review of the R\&D Plans) (CSTP, 2014b).

\section{Figure 16. Structure of governance of the ImPACT programme}

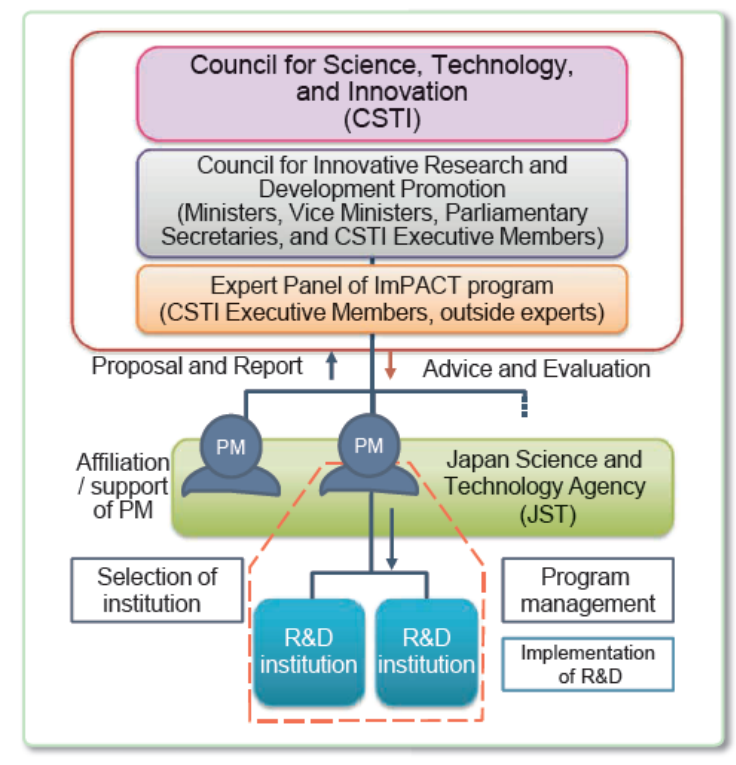

Source: CSTI (2015) 


\subsubsection{Policy implementation}

Once selected the PM was expected to work full-time for the programme as a JST employee, with some flexibility if the PM originated from a university or a research institute in order to preserve its employment contract. Inspired by DARPA's model, the PMs was delegated significant authority to leave them freedom as regards to the use of funds and management of the project with a dedicated team they have composed. As set out in the programme manager applications guideline "the programme manager acts as a producer who casts researchers and bring together capabilities in design and management of $R \& D$ with Japan's highest level capabilities of $R \& D$ " (Cabinet Office, 2014).

The programme manager directly selected the R\&D institutions that were to implement the research under its supervision, without necessarily a call for proposal. The ImPACT expert panel was tasked with the validation of the PM's choice. In case of potential conflict of interest, the Committee for the promotion of ImPACT was the body that made the final approval. This large autonomy came with significant monitoring and evaluation. Each PM reported twice a year to a sub-group of experts from the Expert Panel of the ImPACT programme. The expert panel could ask the PM to revise its plans, however keeping in mind the very features of the programme which are to "encourage high-risk high reward initiatives and to delegate authority to the PM" (Cabinet Office, 2014).

As was case in the FIRST Programme, the ImPACT programme was financed through a multiannual fund, which provides PMs with more flexibility to conduct their projects and adapt to changes and progress.

\section{Box 5. Lessons-learned from FIRST and ImPACT}

Documents prepared by CSTI while developing the Moonshot set out some of the main lessonslearned from previous programmes:

- FIRST was successful in cultivating creative and ingenious research ideas but it sometimes fell short of linking cutting-edged research with radical innovations;

- The directionality of ImPACT tended to hinder the autonomy of researchers: "the more mission-oriented the government's $R \& D$ projects were, the more they tended to hinder the free-minded and audacious imagination of researchers".

- Despite its initial emphasis on high risk and high impact, ImPACT has put too much emphasis on innovations, which resulted in some projects "act as simple bridges to private corporative $R \& D$ activities".

- Some ImPACT projects were too focused on science and technology, while addressing societal problems also require regulatory reforms or system changes;

- Finally, ImPACT has been criticised for the lack of participation by foreign researchers and international collaborations. Because societal challenges are of unprecedented scale and scope, "mission-oriented programs by one country are not enough to realise the final goals".

Sources: CSTI (2019) and CSTI and Headquarters for Healthcare Policy (2020). 


\subsection{Moonshot Research and Development Program}

Moonshot takes over the endeavour to support high risk, high impact R\&D projects. Although it is a totally new programme, it takes on-board the experience and lessons of CSTI's past mission-oriented projects and programs primarily FIRST and ImPACT (Box 5).

Moonshot was designed specifically to avoid the pitfalls experienced by its predecessors. It retains the multiyear funding and the flexible design centred around some core decision makers with strong delegated authority to manage an R\&D project with ambitious goals and assemble the best team to achieve these goals. It departs from ImPACT in its openness to foreign researchers. Other noticeable differences concern features that lie at the core of the mission-oriented approach such as the use of 'inspiring, imaginative and credible' missions (the 7 Moonshot goals), the adoption of a portfolio approach and stage-gate funding mechanism. It is of course far too early to assess whether Moonshot will succeed in avoiding the problems of its predecessors.

The importance of Moonshot for the government shows in its budget. A 5 -year fund of Yen 100bn (about Euro 815 million) was created in FY 2018, ${ }^{27}$ to which Yen 15bn (about Euro 122 million) were added in FY 2019.

The Figure 17 provides a synthetic view of Moonshot. 


\section{2 | MISSION-ORIENTED INNOVATION POLICY IN JAPAN}

Figure 17. Overview of the process, governance and main MOIP features of the Moonshot Research and Development Programme

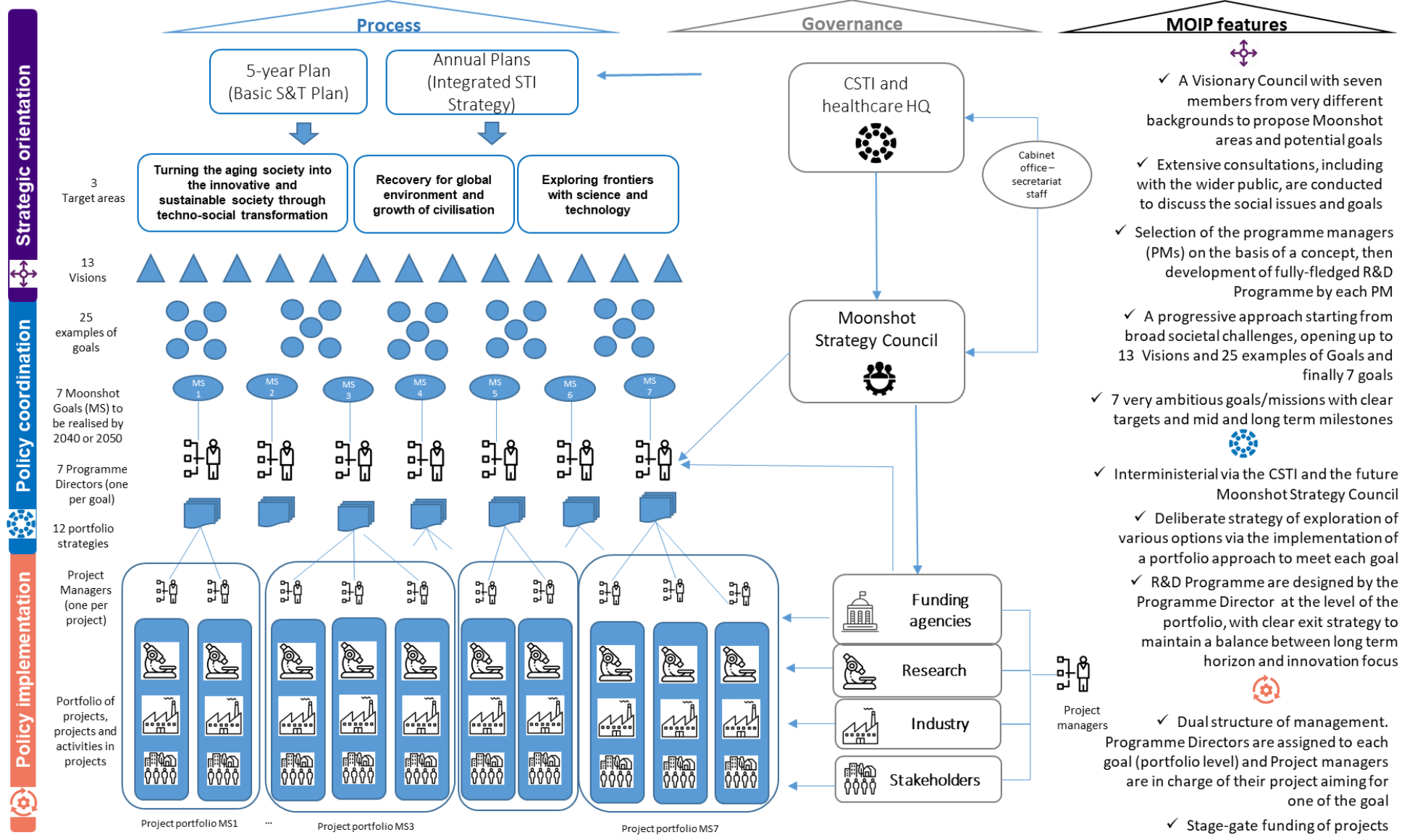

Source: MOIP online toolkit, https://stip.oecd.org/stip/moip 


\subsubsection{Strategic orientation}

Like ImPACT, Moonshot aims to support disruptive innovation. However, compared to its predecessor, it puts more emphasis on addressing societal challenges and is more directional. To assist CSTI in the early design of the Programme, a Visionary Council with seven members was set up in 2019. The Council is chaired by the Chairman of the Board of Mitsubishi Chemical Holdings and is composed of not only industry leaders, renowned academics but also media artists and a writer of science-fiction novels. It was tasked between March and July 2019 with proposing Moonshot areas and potential goals. Extensive consultations with various ministries and agencies took place. The Visionary Council held four meetings and received about 1800 comments to online open call for inputs from the general public. ${ }^{28}$ After the Council had delivered its proposal an international public symposium held in December 2019 gathered a total of 1200 people.

With support from the Cabinet Office secretariat, the Visionary Council adopted a progressive approach starting from broad societal challenges, opening up to numerous Visions and Goals and finally narrowing-down the number of potential options. It went from 3 'Target Areas', to 13 'Visions' to 25 examples of potential goals. 6 Moonshot goal candidates were finally drafted based on the Council's proposal and the discussion at the December 2019 international symposium where 6 working groups discussed subsets of goal candidates and scenarios for achieving them. One additional working group addressed cross-sectional issues. These goals were then discussed in a CSTI expert meeting and finally validated by CSTI in January 2020. An additional goal in the healthcare area was discussed and validated by HQ for Healthcare policy in July 2020.

The three 'Target Areas' are:

1. Turning the aging society into the innovative and sustainable society by harnessing diversity through techno-social transformation

2. Recovery for global environment and growth of civilisation

3. Exploring frontiers with science and technology;

In each of these areas the Council established 'Visions'. 13 Visions were proposed in the end. For instance, 4 Visions were identified to realise the challenge of area 2 (environmental sustainability): Harmonization with nature; Environmentally-neutral cities; Sustainable Resources Circulation; Significant reduction of resource requirements.

The initial six final Moonshot goals are:

1. Realisation of a society in which human beings can be free from limitations of body, brain, space, and time by 2050 ;

1. Realisation of ultra-early disease prediction and intervention by 2050 ;

2. Realisation of AI robots that autonomously learn, adapt to their environment, evolve in intelligence and act alongside human beings, by 2050;

3. Realisation of sustainable resource circulation to recover the global environment by 2050 ;

4. Creation of the industry that enables sustainable global food supply by exploiting unused biological resources by 2050 ;

5. Realisation of a fault-tolerant universal quantum computer that will revolutionize economy, industry, and security by 2050 .

An additional goal was decided by the HQ for Healthcare Policy in July 2020: 
6. Realisation of a sustainable medical and care system to overcome major diseases by 2040, for enjoying one's life with relief and release from health concerns until 100 years old.

Precise targets are set for each of these goals, with at least one target to be achieved by 2030, while all other targets aim for 2040 or 2050 (see 0 ). The underlying idea is that ambitious projects can only be successful in the long term but expected initial gains should be identified in the mid-term to maintain the focus as well as political and public acceptance.

\subsubsection{Policy coordination}

Like it was the case for FIRST and ImPACT, CSTI supervises the whole programme and gives the final validation for all high-level decisions (setting and revision of goals). Like for the SIP, CSTI's leadership covers the whole programme at the exception of the Moonshot goals related to health, which are supervised by the Headquarters for Healthcare Policy. Both headquarters are supported by the Strategy Council which comprises industry leaders, relevant ministries ${ }^{29}$, academics and the executive members of CSTI. The Strategy Council is meant to be the organisational structure that host coordination and collaboration between relevant government bodies to support the projects. It instructs and proposes recommendations to CSTI for all high-level decisions. It will also be in charge of supervising the programme's evaluation. Projects evaluated positively could be supported up to 10 years (hence 2 terms of 5 years, as it is the case for the SIP).

Moonshot, like its predecessor ImPACT, is inspired by DARPA's model of management, granting strong authority to key decision makers. It in a sense combines the 'Core researchers' of FIRST and the Programme managers of ImPACT (and the PD of SIP) by establishing a dual structure of management. One PD is assigned to each goal and is responsible of all projects pursuing that goal. Under their supervision, project managers are in charge of designing the best team to carry out their project.

\subsubsection{Policy implementation}

Different agencies ${ }^{30}$ are in charge of the practical implementation of the programmes dedicated to each goal (funding, appointments, etc.).

Although details on the Programme practicalities are not yet available, a noticeable change with regards to previous practices consists in the adoption of a portfolio approach to manage the high risk of failure of each project considered individually. The main idea is to create an R\&D portfolio system as a package of projects for each Moonshot Goal and evaluate the possibility of achieving a goal of this package, not at the one of each individual project (Ueyama, 2019). 3 to 13 projects were selected per goal (Cabinet Office, 2020). Furthermore, it is expected that PDs will choose projects that try out different paths and methods to meet their respective Moonshot goals. There is therefore a deliberate strategy of exploration of options at the heart of the Moonshot portfolio approach: "the more diversified the program components are, the smaller the total package risk will be, which is why a portfolio approach will be successful" (CSTI, 2019).The 'Strategy Council' is also instrumental for implementing this exploratory approach. Interministerial coordination within this programme governance body will allow balancing their respective investments (Ibid.).

A PD is appointed for each Moonshot goal to supervise the set of projects pursuing this Moonshot Goal in parallel. They are asked to develop an integrated plan regarding how to implement their portfolio of projects. This plan can also integrate external inputs, i.e. results of activities that do not pertain the project portfolio. 
The PD will implement stage-gate reviews of all projects at key milestones. Projects will be discontinued should their prospect for meeting the goal become too limited (Figure 18).

Figure 18. Portfolio of projects pursuing one Moonshot goal

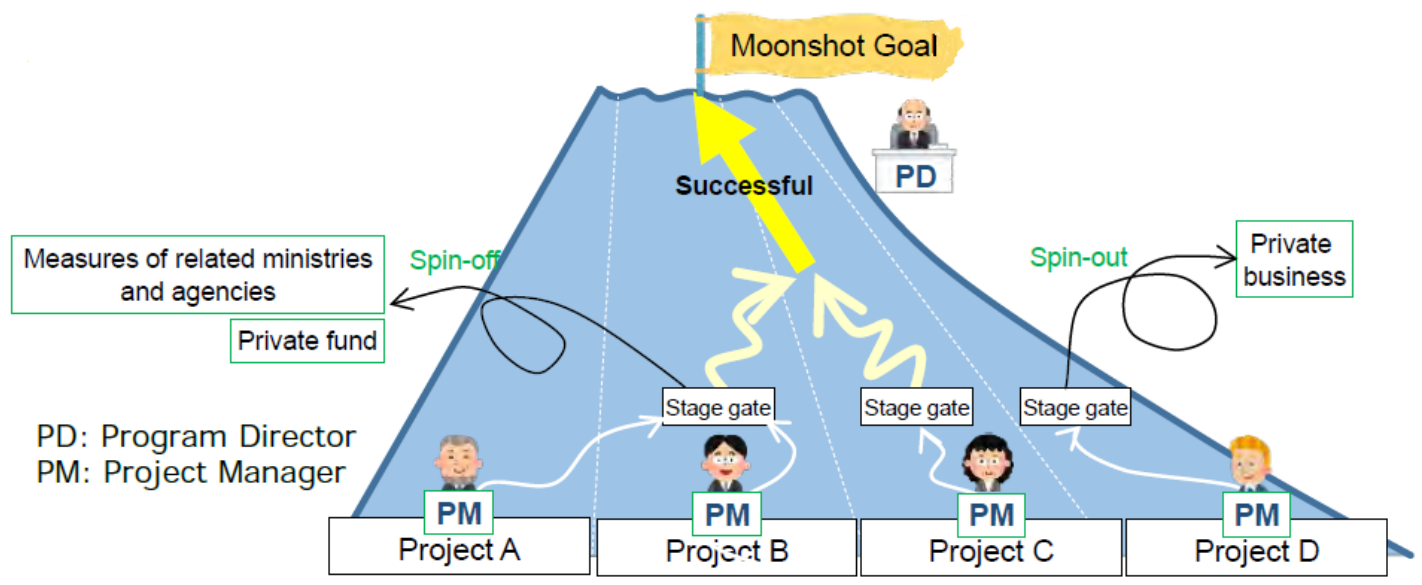

Source: Cabinet Office (2020)

Although the projects have a long-term horizon and are expected to leverage Japanese basic research capabilities the plans established by PMs will have to include exit strategies setting out how the results could be exploited in industry or society (CSTI and Headquarters for Healthcare Policy, 2020).

CSTI plans on developing an evaluation system that accepts unexpected failures and are specific for each 'package'. 


\section{Conclusions and options for the future of the mission-oriented policy agenda in Japan}

\subsection{Japan has become increasingly oriented towards societal challenge missions}

The review of the evolution of the Japanese STI system governance since the 1970s along the three dimensions of mission-orientation reveals that many of the essential features of mission-orientation have been gradually developed and enhanced in particular in the last two decades. Some of these features were already present in the government's goal oriented model of industrial policy up until the end of the 1980s, however in very different forms. As Japan reached the technological frontier, the 1990s marked a transition with repeated calls for the State to focus its intervention to supporting basic research and the setting of conducive framework conditions for innovation. However, as early as the mid-1990s, a new policy trajectory was initiated with the launch of the First Basic Plan.

STI policy has become more top-down, with strong directionality provided by the centerof-government bodies, in particular the Cabinet Office and the successive STI headquarters (CSTP, CSTI, the Integrated Innovation Strategy Promotion Council and some areaspecific headquarters).

Not only the government is setting stronger orientations in its mid-term and annual plans but the nature of these orientations has also changed. They have become less discipline- or technology- based and more challenge-oriented. The latest plans tend to show a balance between, on the one hand, challenge-based priorities that steer activities towards clear goals and, on the other hand, technology-based or disciplinary priorities that allow aiming for goals that are more ambitious.

While consultation with stakeholders has often been limited in the past to industry and academics, the wider public seems increasingly consulted on the social agendas and how STI activities could contribute to a realising the agreed-upon agendas. This is in particular the case in the new mission-oriented programmes like Moonshot that builds upon Visions and Goals that are inspirational and can 'speak to everyone'.

\subsection{Japan has gradually established a singular holistic governance system "from the center"}

STI interministerial coordination has been a concern for several decades in Japan. In the past, each ministry would have its own STI strategy or plan and would negotiate the resources for its implementation with the Ministry of Finance. Efforts to mitigate this problem focused for a long time on enhancing collaboration between METI and MEXT. With the increasing priority put on addressing societal challenges, the scope of interministerial coordination expanded to several sectoral ministries and agencies (environment, agriculture, health, etc.). Interministerial coordination takes place formally in and under the supervision of the Cabinet Office and the high-level STI councils, which were granted increasing authority and a wider mandate to have sufficient bargaining power vis-à-vis individual ministries. It however remains a challenge, as demonstrated by the partial failure of the attempt by CSTI to coordinate ministries' STI budgets.

Interministerial coordination lies also at the core of the mission-oriented programmes led by CSTI, in particular in SIP but also to a lesser - but still significant - extent in ImPACT and Moonshot. Negotiations between ministries in the programmes' governing bodies allow for a more integrated intervention throughout the innovation cycle and a wider policy toolbox from grants to regulatory reforms to support more ambitious projects. Interministerial coordination is also a conducive condition for science-industry cooperation since improved communication and cooperation between the authorities in charge of STI 
policy and sectoral ministries enable a better articulation with the demands and needs for knowledge and innovation.

For two decades, the Cabinet Office - across several political majorities - strived to reinforce the role of the high level councils as STI headquarters in charge of strategic orientation and holistic policy coordination 'from the center'. It has experimented various initiatives to succeed in this endeavour from 'central pots' to fund cross-sectoral projects, central mechanisms to top-up specific projects in ministries (PRISM), processes for budgetary coordination, etc. While these attempts sometimes had mixed results, they demonstrate a strong commitment to improve STI policy making in order to solve increasingly complex and ambitious challenges and an ability to design new bold initiatives.

The last step in 2014 marked a significant change with regards to previous practices not only in Japan but also worldwide: CSTI, was granted a budget and with support from the Cabinet it is now deeply involved, hands-on, in the design and implementation of new STI programmes with strong mission-oriented features. This marks a break from long established division of labour between the Center-of-Government and the ministries. Prior to the change of political majority and the creation of the CSTI, the STI councils were purely advisory and coordination bodies, advising on strategic plans and carrying out 'soft' coordination of different ministries, the latter being the only policy making bodies.

\subsection{Japan has pioneered some purpose-built mission-oriented policy initiatives}

While in most countries mission-oriented policies are still at an infant stage, Japan has as early as in 2014 launched some purpose-built MOIPs, i.e. policy initiatives that do not only have some mission-orientation features but were developed and launched by using the MOIP concept as a blueprint. As it is often the case in Japan, these initiatives draw on international experience (CSTP/CSTI and the White House Office of Science and Technology Policy (OSTP); ImPACT and the DARPA model; Moonshot and the Horizon Europe's five missions), but are specific in many ways in order to adapt to the national context and culture.

They pertain to different types of MOIPs and provide valuable insights for future initiatives in Japan and worldwide (Table 4).

Table 4. Main features of selected MOIP initiatives in Japan

\begin{tabular}{|c|c|c|c|}
\hline & Strategic orientation & Policy coordination & Policy implementation \\
\hline SIP & $\begin{array}{l}\text { - The objective of the programme is to } \\
\text { enhance Japan's economic } \\
\text { competitiveness, while also } \\
\text { addressing important societal } \\
\text { challenges } \\
\text { - Each theme (11 in the first term; } 12 \\
\text { in the second term) is dealt with in a } \\
\text { dedicated SIP programme with its } \\
\text { own 5-year strategy, budget, } \\
\text { leadership and structure of } \\
\text { governance } \\
\text { - Precise goals with deadlines and } \\
\text { milestones for each SIP programme } \\
\text { are negotiated between partners and } \\
\text { policy makers and formalised in its } \\
\text { R\&D Plan } \\
\text { The overall SIP programme has a } \\
\text { strong built-in authority vis-a-vis }\end{array}$ & $\begin{array}{l}\text { - The SIP programme focuses on } \\
\text { areas where interministerial } \\
\text { cooperation is needed for success. } \\
\text { - Each SIP programme has its own } \\
\text { structure of governance involving all } \\
\text { relevant ministries and } \\
\text { representatives of the different } \\
\text { communities at the level of the } \\
\text { overall SIP programme (CSTI; SIP } \\
\text { Governing Board) and at the level of } \\
\text { individual SIP programmes } \\
\text { (Promotion Committee) } \\
\text { - The level of interministerial } \\
\text { cooperation is one of the evaluation } \\
\text { criteria at overall and individual SIP } \\
\text { programme level } \\
\text { The articulation with the demand- } \\
\text { side is key in the SIP. Companies }\end{array}$ & $\begin{array}{l}\text { - The SIP's main objective is to } \\
\text { support in an integrated way the } \\
\text { whole innovation cycle from research } \\
\text { to early market application as well as } \\
\text { any needed regulatory reforms and } \\
\text { system changes. } \\
\text { - Each SIP programme uses different } \\
\text { instruments and policy tools, from } \\
\text { grants to demonstration } \\
\text { programmes, regulatory reforms and } \\
\text { public procurement. The mix of } \\
\text { instruments is fine-tuned by the } \\
\text { Programme Director in order to } \\
\text { achieve the objectives of the R\&D } \\
\text { Plan. } \\
\text { The SIP Programme as a whole and } \\
\text { the SIP individual programmes are } \\
\text { subject to ex ante and ex post }\end{array}$ \\
\hline
\end{tabular}




\begin{tabular}{|c|c|c|c|}
\hline & $\begin{array}{l}\text { ministries and other partners since it } \\
\text { is operated directly by the CSTI } \\
\text { (chaired by the Prime Minister) and } \\
\text { supported by a powerful secretariat } \\
\text { established within the Cabinet Office. } \\
\text { - Each individual programme is led by } \\
\text { a Programme Director with proven } \\
\text { leadership and strong expertise in } \\
\text { the specific topic of their programme. } \\
\text { - Significant programme flexibility } \\
\text { thanks to the decision-making power } \\
\text { of each Programme Director and the } \\
\text { regular revision or R\&D Plans }\end{array}$ & $\begin{array}{l}\text { are partners in all programmes. } \\
\text { - R\&D Plans of individual SIP } \\
\text { programmes put the emphasis on } \\
\text { expected results and their potential } \\
\text { in terms of commercialisation. All } \\
\text { R\&D Plans include 'exit strategies', } \\
\text { 'deployment milestones' or a } \\
\text { 'commercialisation strategy' }\end{array}$ & $\begin{array}{l}\text { evaluations, with several steps of } \\
\text { self-assessment and peer reviews by } \\
\text { specialists. The results of these } \\
\text { evaluations are reflected in the } \\
\text { allocation of the budget in the } \\
\text { following year and can lead to } \\
\text { significant change in the programme } \\
\text { R\&D Plan, governance or } \\
\text { management. }\end{array}$ \\
\hline ImPACT & $\begin{array}{l}\text { - Aims to promote high-risk high- } \\
\text { reward research in } 5 \text { broad themes } \\
\text { where disruptive innovations could } \\
\text { strengthen competitiveness and } \\
\text { overcome important societal } \\
\text { challenges } \\
\text { - Selection of the program managers } \\
\text { on the basis of a concept, then } \\
\text { development of fully-fledged R\&D } \\
\text { Programme by each program } \\
\text { managers a few months after the } \\
\text { selection } \\
\text { - The program managers has the power } \\
\text { to revise the R\&D Programme as } \\
\text { needed }\end{array}$ & $\begin{array}{l}\text { - Interministerial via the CSTI and the } \\
\text { Committee for the Promotion of } \\
\text { ImPACT, in which seat different } \\
\text { policy bodies (including from } \\
\text { Parliament) } \\
\text { - R\&D Programmes are designed using } \\
\text { a backcasting approach to ensure the } \\
\text { articulation with demands and needs }\end{array}$ & $\begin{array}{l}\text { - Financed through a multiannual fund, } \\
\text { which provides program managers } \\
\text { with more flexibility to conduct their } \\
\text { projects and adapt to changes and } \\
\text { progress } \\
\text { - Program managers are granted } \\
\text { significant authority to leave them } \\
\text { freedom as regards the use of the } \\
\text { funds and management of the project } \\
\text { (DARPA's model) } \\
\text { - Program managers assemble their } \\
\text { own dedicated team to ensure the } \\
\text { success of their project } \\
\text { - 'Light' supervision that respects the } \\
\text { freedom of the program managers }\end{array}$ \\
\hline Moonshot & $\begin{array}{l}\text { - A Visionary Council with seven } \\
\text { members from very different } \\
\text { backgrounds is tasked with proposing } \\
\text { Moonshot areas and potential goals } \\
\text { - Extensive consultations, including } \\
\text { with the wider public, are conducted } \\
\text { to discuss the social issues and goals } \\
\text { - A progressive approach starting from } \\
3 \text { broad societal challenges, opening } \\
\text { up to } 13 \text { Visions and } 25 \text { examples of } \\
\text { Goals and } 7 \text { goals finally selected } \\
\text { - } 7 \text { very ambitious goals/missions with } \\
\text { clear targets and mid and long term } \\
\text { milestones (e.g. human beings free } \\
\text { from limitations of body, brain, space, } \\
\text { and time by 2050) }\end{array}$ & $\begin{array}{l}\text { - Interministerial via the CSTI, HQ for } \\
\text { Healthcare policy and the Moonshot } \\
\text { Strategy Council that gather different } \\
\text { ministries } \\
\text { - Strong support from Cabinet Office } \\
\text { secretariat } \\
\text { - Deliberate strategy of exploration of } \\
\text { various options via the } \\
\text { implementation of a portfolio } \\
\text { approach to meet each goal } \\
\text { - R\&D Programme are designed by the } \\
\text { Programme Director at the level of the } \\
\text { portfolio, with clear exit strategy to } \\
\text { maintain a balance between long term } \\
\text { horizon and innovation focus } \\
\text { - Backcasting approach }\end{array}$ & $\begin{array}{l}\text { - Dual structure of management. One } \\
\text { Programme Director is assigned to } \\
\text { each goal and is responsible of all } \\
\text { projects pursuing that goal (portfolio } \\
\text { level). Project managers are in } \\
\text { charge of designing the best team to } \\
\text { carry out their project. } \\
\text { - Stage-gate funding of projects } \\
\text { managed by the Programme Director } \\
\text { for each goal, taking into account the } \\
\text { project portfolio }\end{array}$ \\
\hline
\end{tabular}




\subsection{Options for change}

\subsubsection{Streamline the STI governance structure}

The review of the evolution of the Japanese STI system governance since the 1970s along the three dimensions of mission-orientation reveals that some of the essential features of mission-orientation have been present in Japan's industrial policy since the 1960s. While the policy has changed significantly, the current effort to establish a MOIP approach builds on this long experience.

Following a short 'reinitialisation' period in the 1990s during which Japan STI policy tended to limit itself to horizontal - non-targeted - interventions, a new policy approach with strong mission-orientation features was gradually developed and enhanced in the last two decades.

\section{Table 5. Main mission-orientation features of the current Japanese STI policy model}

\begin{tabular}{|c|c|c|}
\hline Strategic orientation & Policy coordination & Policy implementation \\
\hline $\begin{array}{l}\text { - Significant top down directionality provided } \\
\text { in the Basic S\&T Plans and, in particular, } \\
\text { the annual action plans (Comprehensive / } \\
\text { Integrated innovation strategies) } \\
\text { - Priorities are increasingly issue-based, } \\
\text { replacing the former industry targeting } \\
\text { practices. Issue based priorities are } \\
\text { complemented by disciplinary priorities to } \\
\text { enhance the underpinning scientific } \\
\text { knowledge base. } \\
\text { - Gradual strengthening of the role of } \\
\text { center-of-government bodies, in particular } \\
\text { the Cabinet Office and the successive 'STI } \\
\text { control towers' (CSTP, CSTI, the } \\
\text { Integrated Innovation Strategy Promotion } \\
\text { Council and the thematic headquarters). } \\
\text { - Recent improvement with regards to } \\
\text { consultations of a wider range of } \\
\text { stakeholder beyond the 'usual suspects' }\end{array}$ & $\begin{array}{l}\text { - Long tradition of STI interministerial } \\
\text { coordination to enhance collaboration, } \\
\text { notably between METI and MEXT } \\
\text { - Gradual strengthening of the holistic } \\
\text { coordination mandate and power of CSTP } \\
\text { then CSTI } \\
\text { - Attempt to set a holistic STI budget } \\
\text { formation process led by CSTI, however } \\
\text { with mixed results } \\
\text { - Recent initiative to expand the range of } \\
\text { coordination to better include 'sectoral' } \\
\text { policy bodies (ministries but also central } \\
\text { thematic 'headquarters') beyond those } \\
\text { directly in charge of research and } \\
\text { innovation. } \\
\text { - Growing complexity of the governance } \\
\text { system in involving ministries, the STI } \\
\text { control tower (CSTI), the thematic } \\
\text { headquarters and the new council to } \\
\text { coordinate all these actors } \\
\text { - Interministerial coordination at the core of } \\
\text { the SIP programme }\end{array}$ & $\begin{array}{l}\text { - Research consortia during the catch-up } \\
\text { period had several MOIP features } \\
\text { - Fully-fledged mission-oriented } \\
\text { programmes led by CSTI: SIP, Moonshot } \\
\text { and ImPACT }\end{array}$ \\
\hline
\end{tabular}

These efforts to improve policy orientation, coordination and, since 2014, implementation led by the centre of government have however significantly increased the complexity of the STI system governance and the associated transaction costs.

\section{Recommendation on the streamlining of the holistic STI coordination structure}

There is a need to streamline the structure of STI governance, in particular with regards to the division of responsibilities between the different STI headquarters (CSTI on one side and the area-specific headquarters like the Health and Healthcare policy HQ on the other side). The current preparation of the Sixth Basic Plan, due in December 2020, with a final cabinet decision in the first quarter of 2021, could be an occasion to rethink the governance of the system. 


\subsubsection{Societal challenges at the core of the Next Basic Plan}

When the Fifth Basic Plan was prepared in 2016, the UN SDG framework had not yet been released and therefore could not be integrated in the Plan. The Society 5.0 vision was however seen as very consistent with the 17 SDGs. It is possible that it serves as an important structuring component of the Sixth Basic Plan, while keeping the Society 5.0 vision. The Cabinet Office is currently leading the efforts to promote relevant STI policies for addressing SDGs. Against this backdrop, an STI for SDGs Task Force was created under CSTI, involving a large panel of stakeholders from public and private sectors. With the support from this Task Force and the Cabinet Office, CSTI has also formulated a 'STI for SDGs' roadmap (Cabinet Office, 2018). The latter identifies and integrates the various national strategies, plans and policies related to the 17 SDGs, including their respective milestones and timeframe.

Recommendation to strengthen the shift towards a societal challenge-driven agenda in the sixth Basic Plan

CSTI is due to develop a vision for STI in 2030 to guide the two next Basic Plans. This Vision could strengthen the shift towards a societal challenge-driven agenda clearer and more pronounced than in the Fifth Basic Plan. The sixth Basic Plan could provide an overarching framework for performing the STI components of the initiatives included in the roadmap.

\subsubsection{CSTI as a ground for policy experimentation}

The supervision by CSTI of the mission-oriented programmes improves interministerial cooperation, leadership and allows to break away with ministries' established practices and culture in order to experiment new policy concepts. These growing responsibilities of the CSTI have however generated a very important workload for its executive members, to the detriment of some of its core function in the orientation and coordination of the STI system as a whole, hence not only in the remit of these new programmes.

More fundamentally, the new policy configuration established in 2014 has blurred the frontier between the two groups of key functions of strategy/coordination on the one side and implementation/management on the other side. Each of these functions requires very different capabilities and access to specific resources. This, together with the need to avoid potential conflicts of interest, explains in great part why there are under the remit of different bodies in most national innovation systems.

While the strengthening of the command tower function has improved STI holistic coordination, it has somewhat reduced the involvement of ministries in the policy formation process, in particular when it comes to the final decisions and arbitrages (Kobayashi et al., 2019). This can be in certain cases detrimental since ministries have privileged access to essential information and expertise provided by their respective communities of the stakeholders and partners (universities, research institutes, business firms).

Recommendation to use CSTI as a ground for experimentation for MOIP experimentation before mainstreaming of these policies 
CSTI should be considered as a ground for experimentation to launch, test and improve new policy initiatives, such as mission-oriented policies, which require stronger orientation and coordination. There should also be an 'exit strategy' to ensure the sustainability of both these initiatives and the headquarter function. This exit strategy would consist of a process for transferring these initiatives, once well established and functioning, to a set of inter-connected ministries. CSTI could retain an important role in the overall holistic supervision and monitoring \& evaluation of these initiatives.

\subsubsection{Evaluate and learn from MOIPs'strengths and weaknesses}

SIP and ImPACT are two of the very few fully-fledged mission-oriented innovation policy initiatives worldwide that have been operating during an entire programmatic cycle. They offer the experience of two very different types of MOIPs. Other countries can learn from their respective strengths and limitations. Although still only at the inception stage, Moonshot is also a valuable variant of a 'DARPA-style' challenge-based programme with very ambitious goals, which will enrich the international knowledge base on MOIPs.

Both SIP and ImPACT have gone through an evaluation following the end of their first term. As it is often the case in Japan, these evaluations are made by Japanese experts and their results are not disseminated internationally.

Recommendation to enhance the reflexivity of MOIP through adapted evaluations

The MOIPs could be subject to external evaluations, if possible with the participation of international experts and peers and following well-established evaluation practices. The international community of STI policy makers would benefit from the dissemination of their results. Ensuing discussions and exchanges would also be beneficial to Japanese policy makers.

Dedicated reflection should be engaged to develop evaluation methodologies and process adapted to the specificies of MOIPs.

\subsubsection{Lean and integrated mission-oriented innovation policy initiatives}

The SIP and ImPACT (and maybe Moonshot in the future) are remarkable mission-oriented innovation policy initiatives from which other countries can learn. While Moonshot is only starting, SIP and ImPACT have already produced significant results. They however show that the articulation between the advancement of knowledge, the production of innovation and the creation of economic and social value is still a challenge. Some SIP programmes have been criticised for being too science-based, others too incremental. The creation of an integrated support throughout the entire innovation cycle within these programmes should be a priority in the future. ${ }^{31}$

Recommendation for agency-led MOIPs supporting innovation projects throughout the entire innovation cycle

Japan could complement the current MOIPs led by the Cabinet Office with more bottom-up initiatives such as those experimented in Norway under the name of Pilot-X (notably Pilot-E in clean energy technology). Run cooperatively by a group of agencies to cover seamlessly the whole innovation chain, these initiatives are light and agile and have already demonstrated positive results. 


\section{Glossary}

\begin{tabular}{|c|c|}
\hline AIST: & Advanced Industrial Science and Technology \\
\hline CEFP: & Council for Economic and Fiscal Policy \\
\hline CoG: & Center-of-Government \\
\hline CRDS: & Center for Research and Development Strategy \\
\hline CST: & Council for Science and Technology \\
\hline CSTI: & Council for Science, Technology and Innovation \\
\hline CSTP: & Council for Science and Technology Policy \\
\hline DARPA: & Defense Advanced Research Projects Agency \\
\hline ERA: & Engineering Research Associations \\
\hline FCCJ: & Fuel Cell Commercialization Conference of Japan \\
\hline GSF: & Global Science Forum \\
\hline HQ: & Headquarters \\
\hline ImPACT: & Impulsing PAradigm Change through disruptive Technologies program \\
\hline ITS: & Intelligent Transport Systems \\
\hline JST & Japan Science and Technology Agency \\
\hline LIBES: & Lithium Battery Energy storage consortium \\
\hline MAFF & Ministry of Agriculture, Forestry and Fisheries \\
\hline METI: & Ministry of Economy, Trade and Industry \\
\hline MEXT: & Ministry of Education, Culture, Sports, Science and Technology \\
\hline MHLW: & Ministry of Health, Labour and Welfare \\
\hline MIC: & Ministry of Internal Affairs and Communications \\
\hline MITI: & Ministry of International Trade and Industry \\
\hline MOF: & Ministry of Finance \\
\hline MOIP: & Mission-Oriented Innovation Policy \\
\hline NIMS: & National Institute of Materials Science \\
\hline NISTEP: & National Institute of Science and Technology Policy \\
\hline OECD: & Organisation for Economic Co-operation and Development \\
\hline OECD-CSTP: & OECD Committee for Scientific and Technological Policy \\
\hline PD & Programme Director \\
\hline PDCA: & Plan Do Check Act \\
\hline PM & Project Manager \\
\hline R\&D: & Research and Development \\
\hline SDG: & Sustainable Development Goal \\
\hline SIP: & Cross-ministerial Strategic Innovation Promotion Program \\
\hline SSH: & Social Sciences and Humanities \\
\hline STA: & Science and Technology Agency \\
\hline STI: & Science, Technology and Innovation \\
\hline TSC: & Technology Strategy Center \\
\hline VLSI: & Very large-scale integration consortium \\
\hline
\end{tabular}




\section{References}

Aoki M., H.K. Kim, Okuno-Fujiwara, (1998), The Role of Government in East Asian Economic Development: Comparative Institutional Analysis, Oxford University Press.

Arimoto and Oyamada (2020), From Traditional to HRHR Funding Mechanisms - A comparative perspective from Japan, Presentation at the OECD/GSF Virtual Workshop on "Effective Policies to Foster High Risk/High Reward Research", 22 April 2020.

Cabinet Office (2011), Science and Technology Innovation Strategy Headquarters, https://www8.cao.go.jp/cstp/stsonota/kenkyukai/1kai/siryo3.pdf (in Japanese)

Cabinet Office (2014), ImPACT Programme Manager application guideline.

Cabinet Office (2017), Healthcare Policy, Revised version https://www.kantei.go.jp/jp/singi/kenkouiryou/en/pdf/2017_policy.pdf

Cabinet Office (2020), 'STI for SDGs Roadmap (Tentative)' March 25, 2020, Cabinet Office, Government of Japan' https://www8.cao.go.jp/cstp/english/roadmap_e.pdf

Cabinet Office (2019), Target values and indicators of the 5th Science and Technology Basic Plan, https://www8.cao.go.jp/cstp/kihonkeikaku/sihyou/data1.pdf (in Japanese).

Cabinet Office (2020), Moonshot Goals for the Moonshot Research and Development Program, Bureau of Science, Technology and Innovation, https://www8.cao.go.jp/cstp/english/moonshot/outline_en.pdf

Callon S., (1995), Divided sun: MITI and the breakdown of Japanese high-tech industrial policy, Stanford University Press, $240 \mathrm{p}$.

Carraz R., Harayama Y., (2018), Japan's Innovation Systems at the Crossroads: Society 5.0, Panorama: Insights into Asian and European Affairs, 33-45, https://www.kas.de/documents/288143/4843367/panorama_digital_asia_v3a_Carraz_Har ayama.pdf/b57f6b67-f317-cfc5-010c-4ee501c3a398

Committee on the History of Japan's Trade and Industry Policy RIETI (2020), Dynamics of Japan's Trade and Industrial Policy in the Post Rapid Growth Era (1980-2000), RIETI, Springer.

Council for Science and Technology (2015), Japan's STI policies looking beyond mid-long term-towards the $5^{\text {th }}$ Basic Plan, Interim Report proposed by the Council for Science and Technology, January, MEXT.

Council for Science and Technology Iolicy (2014b), Basic Policy for Management of the Impulsing Paradigm Change through Disruptive Technologies (ImPACT) Program, https://www.jst.go.jp/impact/en/data/basicpolicy.pdf

Council for Science and Technology Policy (2014a), Guidelines for Handling Basic Policy for Management of the Impulsing Paradigm Change through Disruptive Technologies (ImPACT) Program, https://www.jst.go.jp/impact/en/data/Guidelines_for_Handling.pdf

Council for Science, Technology and Innovation (2015), Brochure about the Council for Science, Technology and Innovation, https://www8.cao.go.jp/cstp/english/panhu/index.html

Council for Science, Technology and Innovation (2019), The Management of the Moonshot and new Policy-making in STI, Management Paper, Moonshot International Symposium December 17, 2019, 
Council for Science, Technology and Innovation and Headquarters for Healthcare Policy (2018), The basic approach for the Moonshot Research and Development Program, December 20, 2018, Partial Revision February 27, 2020 https://www8.cao.go.jp/cstp/english/moonshot/basicapproach_en.pdf

Elder M., (2003), METI and industrial policy in Japan, in Schaede U., Grimes W.W., Japan's managed globalization, Adapting to the Twenty-First Century, East Gate, pp. 159190.

European Commission (2018), Mission-Oriented Research and Innovation Inventory: and characterisation of initiatives, http://dx.doi.org/10.2777/697082.

European Commission (2018), Mission-Oriented Research and Innovation: Assessing the impact of a mission-oriented research and innovation approach, http://dx.doi.org/10.2777/373448.

Government of Japan (1995), Science and Technology Basic Plan, Unofficial Translation, https://www8.cao.go.jp/cstp/english/basic/1st-BasicPlan_96-00.pdf

Government of Japan (2001), The Science and Technology Basic Plan (2001-2005), Tentative Translation, https://www8.cao.go.jp/cstp/english/basic/2nd-BasicPlan 0105.pdf

Government of Japan (2006), Science and Technology Basic Plan, Provisional Translation, https://www8.cao.go.jp/cstp/english/basic/3rd-Basic-Plan-rev.pdf

Government of Japan (2010), Japan's Science and Technology Basic Policy Report https://www8.cao.go.jp/cstp/english/basic/4th-BasicPolicy.pdf

Government of Japan (2014), Comprehensive Strategy on Science, Technology and Innovation 2014 - Bridge of Innovation toward Creating the Future, Provisional Translation, https://www8.cao.go.jp/cstp/english/doc/2014stistrategy_provisonal.pdf.

Government of Japan (2014), Comprehensive Strategy on Science, Technology and Innovation 2014 - Bridge of Innovation toward Creating the Future (executive summary), Provisional Translation, https://www8.cao.go.jp/cstp/english/doc/cssti2014-03.pdf

Government of Japan (2016), The Fifth Science and Technology Basic Plan, Provisional Translation, https://www8.cao.go.jp/cstp/english/basic/5thbasicplan.pdf

Government of Japan (2018), Integrated Innovation Strategy, Provisional Translation, https://www8.cao.go.jp/cstp/english/doc/integrated_main.pdf

Government of Japan (2019), Integrated Innovation Strategy (outline), Forthcoming.

Hane, G.J. (1993),The real lessons of Japanese research consortia, Journal of Technology Transfer, 18, 35-42 https://doi.org/10.1007/BF02174801

Harayama Y. (2001), Japanese Technology Policy: History and New Perspective, RIETI Discussion Paper, 01-E-001.

Harayama Y. (2001), Japanese Technology Policy: History and New Perspective, RIETI Discussion Paper, 01-E-001, https://www.rieti.go.jp/jp/publications/dp/01e001.pdf.

Izumi H. (2019), Japan's innovation strategy and the bioeconomy strategy 2019, Document dated October 92019.

Izumi H. (2019), Japan's innovation strategy and the bioeconomy strategy 2019, document dated October 92019. 
Johnson C., (1982), MITI and the Japanese miracle, the growth of industrial policy, 1925 1975, Stanford University Press, 409 p.

Kageyama K. (1998) Frontier: Japan 1997-1998, Issue 18, February.

Kang D., Jang W., Kim Y. and Jeon J. (2019), “Comparing National Innovation System among the USA, Japan, and Finland to Improve Korean Deliberation Organization for National Science and Technology Policy", Journal of Open Innovation: Technology, Market, and Complexity, 5, 82; https://www.mdpi.com/2199-8531/5/4/82/pdf

Kato T. (2019), Technology Strategy Center (TSC) Activities in the Bioeconomy Field, TSC, NEDO, https://www.nedo.go.jp/content/100890875.pdf

Kawamura T., Takeda H. (2014), Outline of Trade and Industry Policy (1980-2000) -Summary of "History of Trade and Industry Policy - Industrial Technology Policy" by Minoru Sawai, RIETI Policy Discussion Paper Series 14-P-016, Research Institute of Economy, Trade and Industry, https://www.rieti.go.jp/jp/publications/pdp/14p016.pdf.

Kobayashi S., Akaike S., Hayashi T., Tomiza H. (2019), Transition of Science and Technology Basic Plan and Future Prospect, The Journal of Science Policy and Research Management, Vol 34, Issue 3, https://doi.org/10.20801/jsrpim.34.3_190.

Larrue, P. (2021), "The design and implementation of mission-oriented innovation policies: A new systemic policy approach to address societal challenges", OECD Science, Technology and Industry Policy Papers, No. 100, OECD Publishing, Paris, https://doi.org/10.1787/3f6c76a4-en.

Lechevalier S., Debanes P., Wonkyu S. (2016), Financialization and industrial policies in Japan and Korea: Evolving complementarities and loss of institutional capabilities, INCAS Series Discussion Paper, Series 2016 \#01, https://halshs.archives-ouvertes.fr/halshs$\underline{01431783 / \text { document }}$

Lee S. Peterson S., (2000) "Culture, Entrepreneurial Orientation, and Global Competitiveness." Journal of World Business, 35, no. 4, https://doi.org/10.1016/S1090$\underline{9516(00) 00045-6}$

Mazzucato, M. (2018), Mission-Oriented Research and Innovation in the European Union - A problem-solving approach to fuel innovation-led growth, Directorate-General for Research and Innovation, European Commission, European Commission, http://dx.doi.org/10.2777/36546.

MEXT (2019), White Paper on Science and Technology 2019 (Provisional Translation), https://www.mext.go.jp/en/publication/whitepaper/title03/detail03/1420912 01.html

Motohashi (2011), Innovation Policy Challenges for Japan - An Open and Global Strategy, Asie Visions, 45 IFRI Center for Asian Studies, https://www.ifri.org/sites/default/files/atoms/files/asievisions45kmotohashi.pdf

National Research Council (2009), 21st Century Innovation Systems for Japan and the United States: Lessons from a Decade of Change: Report of a Symposium, Washington, DC: The National Academies Press. https://doi.org/10.17226/12194.

OECD (2019a), Measuring Distance to the SDG Targets 2019: An Assessment of Where OECD Countries Stand, OECD Publishing, Paris, https://doi.org/10.1787/a8caf3fa-en.

OECD (2019b), Government at a Glance 2019, OECD Publishing, Paris, https://doi.org/10.1787/8ccf5c38-en.

OECD (2019c), R\&D tax incentives in Japan 2019, http://www.oecd.org/sti/rd-tax-statsjapan.pdf. 
Sakakibara M., (1997), Evaluating government-sponsored R\&D consortia in Japan: who benefits and how?, Research Policy, 26, pp. 447-473.

Sato. Y, Arimoto T. (2015), Japan, in UNESCO Science Report: towards 2030, UNESCO, https://en.unesco.org/sites/default/files/usr15 japan.pdf.

Schaede U., (2000), Cooperative capitalism, Self-regulation, trade associations, and the antimonopoly law in Japan, Oxford University Press, Oxford, 293 p.

Schaede U., Grimes W.W., (2003), Introduction, The emergence of Permeable insulation, in Schaede U., Grimes W.W., Japan's managed globalization, Adapting to the TwentyFirst Century, East Gate, pp. 3-15.

Stenberg L., Nagano H. (2009), Priority-Setting in Japanese Research and Innovation Policy, Vinnova Analysis 2009-23, https://www.vinnova.se/contentassets/d1060bb3bcdf478ba9519956f3c775df/va-0923.pdf

Takeyasu Y., Okuma K., Arimoto T., Kuniya M. (2009), History of Science and Technology Agency, The Science News, Tokyo.

Ueyama T. (2018), “Innovationalizing” government investment: Japan's new STI policies, Presentation at the December 2018 Abe Global Forum, https://carnegieendowment.org/files/TakahiroUeyamaPresentation.pdf.

Ueyama T. (2019), The Management of the Moonshot and new Policy-making in STI, Presentation at the Moonshot Symposium, December 17, 2019, https://www.jst.go.jp/moonshot/sympo/sympo2019/material/day1_ps1_ueyama_2019121 7 discussion.pdf

Vogel S.K., (1996), Freer markets, more rules, Regulatory reform in advanced industrial countries, Cornell University Press, New York.

Woolgar L. (2012), ERAwatch Country Reports 2012 - Japan, ERAwatch Network, European Commission, https://rio.jrc.ec.europa.eu/library/erawatch-country-report-japan$\underline{2012}$

Yamaya K. (2015), Councils, policy analysis and policy evaluation, in Adachi Y., Hosono S., Lio J., , Policy analysis in Japan, International Library of Policy Analysis, Bristol University Press, Policy Press. 
Annex A. List of Interviewees

\begin{tabular}{|l|l|}
\hline HARAYAMA Yuko & $\begin{array}{l}\text { Professor, Tohoku University } \\
\text { Executive Director for International Affairs, RIKEN } \\
\text { Former Executive member of CSTI }\end{array}$ \\
\hline HASHIMOTO Kazuhito, & Executive member of CSTI and president of NIMS \\
\hline KAWAUCHI Yukio & Policy Information Analyst, MAFF \\
\hline KIKUCHI Kumiko & $\begin{array}{l}\text { Deputy Director, Bureau of Science, Technology and } \\
\text { Innovation Policy, Cabinet Office }\end{array}$ \\
\hline KURAMOCHI Takao & Deputy Director-General of CRDS, JST \\
\hline MISHIMA Yoshinao & Director-General, Technology Strategy Center, NEDO \\
\hline MIZUMOTO Shinichi & $\begin{array}{l}\text { Director for international affairs, Bureau of Science, } \\
\text { Technology and Innovation Policy, Cabinet Office }\end{array}$ \\
\hline SAKODA Kenkichi & Deputy Director, Moonshot office, Cabinet Office \\
\hline SUZUKI Shinji & $\begin{array}{l}\text { Deputy Director, Emerging/Integrated Area Research } \\
\text { and Development Research Strategy Office, MEXT }\end{array}$ \\
\hline SUZUKI Tomio & $\begin{array}{l}\text { Director, Project preparation office, } \\
\text { Agriculture and Food Research Organization }\end{array}$ \\
\hline TAKEGAMI Naoya & Deputy Director, Policy promotion office, MEXT \\
\hline TAKEMURA Masahiro & Counsellor, SIP office, JST \\
\hline TOMONAGA Yuto & $\begin{array}{l}\text { Unit Chief, SIP office, Bureau of Science, Technology } \\
\text { and Innovation Policy, Cabinet Office }\end{array}$ \\
\hline UEYAMA Takahiro & Full-time executive member of CSTI \\
\hline YOSHIDA Kazuhisa & Fellow, CRDS, JST \\
\hline
\end{tabular}

Note: The affiliations and titles are those valid at the time of the interview (Dec. 2019).) 


\section{Annex B. SIP Individual Programmes}

In its first term, the SIP (2014-2018) has identified 11 themes where STI progress could help address the most important social problems facing Japan and contribute to the resurgence of the Japanese economy.

1. Innovative Combustion Technology

2. Next-generation Power Electronics

3. Structural Materials for Innovation

4. Energy Carriers

5. Next-generation Technology for Ocean Resources Exploration

6. Automated Driving System for Universal Services

7. Infrastructure Maintenance Renovation and Management

8. Enhancement of Societal Resiliency against Natural Disasters

9. Technologies for Creating Next-generation Agriculture, Forestry and Fisheries.

10. Innovative Design/Manufacturing Technologies

11. Cyber-security for Critical Infrastructure (since FY 2016)

In its second term (2018-2022), the SIP focus on 12 themes:

12. Big data and AI-enabled cyberspace technologies

13. Intelligent knowledge processing infrastructure integrating physical and virtual domains

14. Cyber physical security for the Internet of Things society

15. Automated driving for universal services

16. "Materials integration" for revolutionary design system of structural materials

17. Photonics and quantum technology for Society 5.0

18. Technologies for smart bio-industry and agriculture

19. Energy systems toward the Internet of Energy society

20. Enhancement of national resilience against natural disasters

21. Innovative AI hospital system

22. Smart logistics service

23. Innovative technology for exploration of deep sea resources 


\section{Annex C. FIRST Projects}

\begin{tabular}{|c|c|c|c|}
\hline Core-Researcher's Name & $\begin{array}{r}\text { Core-Researcher's } \\
\text { Affiliation } \\
\end{array}$ & $\begin{array}{r}\begin{array}{r}\text { Operational support } \\
\text { institutions }\end{array} \\
\end{array}$ & Research Subject \\
\hline Kazuyuki AlHARA & The University of Tokyo & $\begin{array}{r}\text { Japan Science and } \\
\text { Technology Agency (JST) }\end{array}$ & $\begin{array}{l}\text { Mathematical Theory for Modelling Complex } \\
\text { Systems and its Transdisciplinary Applications } \\
\text { in Science and Technology }\end{array}$ \\
\hline Shizuo AKIRA & Osaka University & Osaka University & $\begin{array}{r}\text { Comprehensive understanding of immune } \\
\text { dynamism : toward manipulation of immune } \\
\text { responses }\end{array}$ \\
\hline Chihaya ADACHI & Kyushu University & Kyushu University & $\begin{array}{l}\text { Challenges for super organic } \\
\text { electroluminescence devices through } \\
\text { innovation of organic semiconducting materials }\end{array}$ \\
\hline Yasuhiko ARAKAWA & The University of Tokyo & $\begin{array}{r}\text { Photonics Electronics } \\
\text { Technology Research } \\
\text { Association } \\
\end{array}$ & $\begin{array}{r}\text { Technology Development for Photonic- } \\
\text { Electronic Integration System }\end{array}$ \\
\hline Masayoshi ESASHI & Tohoku University & Tohoku University & $\begin{array}{r}\text { Research and development of integrated } \\
\text { microsystems }\end{array}$ \\
\hline Hideo OHNO & Tohoku University & Tohoku University & $\begin{array}{r}\text { Research and Development of Ultra-low Power } \\
\text { Spintronics-based Logic VLSIs }\end{array}$ \\
\hline Teruo OKANO & $\begin{array}{r}\text { Tokyo Women's Medical } \\
\text { University }\end{array}$ & $\begin{array}{r}\text { Japan Science and } \\
\text { Technology Agency (JST) }\end{array}$ & $\begin{array}{r}\text { System Integration for Industrialization of } \\
\text { Regenerative Medicine: Creation of Organ } \\
\text { Factory }\end{array}$ \\
\hline Hideyuki OKANO & Keio University & RIKEN & $\begin{array}{r}\text { Strategic Exploitation of Neuro-Genetics for } \\
\text { Emergence of the Mind }\end{array}$ \\
\hline Kazunori KATAOKA & The University of Tokyo & $\begin{array}{r}\text { Japan Science and } \\
\text { Technology Agency (JST) }\end{array}$ & $\begin{array}{r}\text { Development of Innovative Diagnostic and } \\
\text { Therapeutic Systems Based on } \\
\text { Nanobiotechnology }\end{array}$ \\
\hline Tomoji KAWAI & Osaka University & Osaka University & $\begin{array}{l}\text { Research and Development of Innovative } \\
\text { Nanobiodevices Based on Single-Molecule } \\
\text { Analysis -Ultra-fast Single-Molecule-DNA } \\
\text { Sequencing, Ultra-Low-Concentration Virus } \\
\text { Detection, and Ultra-Sensitive Biomolecule } \\
\text { Monitoring- }\end{array}$ \\
\hline Masaru KITSUREGAWA & The University of Tokyo & The University of Tokyo & $\begin{array}{l}\text { Development of the Fastest Database Engine } \\
\text { for the Era of Very Large Database and } \\
\text { Experiment and Evaluation of Strategic Social } \\
\text { Services Enabled by the Database Engine }\end{array}$ \\
\hline Tsunenobu KIMOTO & Kyoto University & $\begin{array}{r}\text { National Institute of Advanced } \\
\text { Industrial Science and } \\
\text { Technology (AIST) }\end{array}$ & $\begin{array}{r}\text { Innovative SiC Power Electronics Technology } \\
\text { Toward Low-Carbon Society }\end{array}$ \\
\hline Masaru KURIHARA & Toray Industries, Inc. & $\begin{array}{r}\text { New Energy and Industrial } \\
\text { Technology Development } \\
\text { Organization (NEDO) }\end{array}$ & Mega-ton Water System \\
\hline Yasuhiro KOIKE & Keio University & Keio University & $\begin{array}{l}\text { Creation of Face-to-Face Communication } \\
\text { Industry by Ultra High-Speed Plastic Optical } \\
\text { Fiber and Photonics Polymers for High- } \\
\text { Resolution and Large-Size Display }\end{array}$ \\
\hline Tatsuhiko KODAMA & The University of Tokyo & 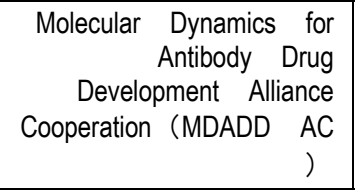 & $\begin{array}{r}\text { Molecular Dynamics Initiative for Antibody Drug } \\
\text { Development (MDADD) }\end{array}$ \\
\hline Yoshiyuki SANKAI & University of Tsukuba & University of Tsukuba & $\begin{array}{l}\text { World leading human-assistive technology } \\
\text { supporting a long-lived and healthy society }\end{array}$ \\
\hline Hiroki SHIRATO & Hokkaido University & Hokkaido University & $\begin{array}{l}\text { Advanced Radiation Therapy Project -Real- } \\
\text { time Tumor-tracking with Molecular Imaging } \\
\text { Technique- }\end{array}$ \\
\hline Hiroshi SEGAWA & The University of Tokyo & New Energy and Industrial & Development of Organic Photovoltaics toward a \\
\hline
\end{tabular}


70 | MISSION-ORIENTED INNOVATION POLICY IN JAPAN

\begin{tabular}{|c|c|c|c|}
\hline & & $\begin{array}{l}\text { Technology Development } \\
\text { Organization (NEDO) }\end{array}$ & $\begin{array}{l}\text { Low-Carbon Society: Pioneering Next } \\
\text { Generation Solar Cell Technologies and } \\
\text { Industries via Multi-manufacturer Cooperation }\end{array}$ \\
\hline Koichi TANAKA & Shimadzu Corporation & $\begin{array}{r}\text { Japan Science and } \\
\text { Technology Agency (JST) }\end{array}$ & $\begin{array}{l}\text { Contribution toward drug discovery and } \\
\text { diagnosis by next generation of advanced mass } \\
\text { spectrometry system }\end{array}$ \\
\hline Yoshinori TOKURA & The University of Tokyo & RIKEN & Quantum Science on Strong Correlation \\
\hline Akira TONOMURA & Hitachi, Ltd. & $\begin{array}{r}\text { Japan Science and } \\
\text { Technology Agency (JST) }\end{array}$ & $\begin{array}{l}\text { Development and Application of Atomic- } \\
\text { Resolution Holography Electron Microscope }\end{array}$ \\
\hline Ryozo NAGAI & The University of Tokyo & The University of Tokyo & $\begin{array}{r}\text { Development of optimized therapeutic } \\
\text { strategies against cancer and cardiovascular } \\
\text { disease using large-scale computing and } \\
\text { clinical information }\end{array}$ \\
\hline Shinichi NAKASUKA & The University of Tokyo & The University of Tokyo & $\begin{array}{l}\text { Establishment of New Paradigm of Space } \\
\text { Development and Utilization with Nano- } \\
\text { Satellites Introducing Japanese-Original } \\
\text { "Reasonably Reliable Systems Engineering" }\end{array}$ \\
\hline Hideo HOSONO & $\begin{array}{r}\text { Tokyo Institute of } \\
\text { Technology }\end{array}$ & Tokyo Institute of Technology & $\begin{array}{l}\text { Exploration of New Superconductors and } \\
\text { Related Functional Materials and Application of } \\
\text { Superconducting Wires for Industry }\end{array}$ \\
\hline Noritaka MIZUNO & The University of Tokyo & The University of Tokyo & $\begin{array}{r}\text { Innovative Basic Research Toward Creation of } \\
\text { High-performance Battery }\end{array}$ \\
\hline Hitoshi MURAYAMA & The University of Tokyo & The University of Tokyo & $\begin{array}{l}\text { Uncovering the Origin and Future of the } \\
\text { Universe-ultra-wide-field imaging and } \\
\text { spectroscopy reveal the nature of dark matter } \\
\text { and dark energy }\end{array}$ \\
\hline Masashi YANAGISAWA & University of Tsukuba & University of Tsukuba & $\begin{array}{r}\begin{array}{r}\text { Molecular Mechanism and Control of Complex } \\
\text { Behaviors }\end{array} \\
\end{array}$ \\
\hline Shinya YAMANAKA & Kyoto University & Kyoto University & iPS Cell Project for Regenerative Medicine \\
\hline Yoshihisa YAMAMOTO & $\begin{array}{r}\text { National Institute of } \\
\text { Informatics, Research } \\
\text { Organization of Information } \\
\text { and Systems }\end{array}$ & $\begin{array}{r}\text { National Institute of } \\
\text { Informatics }\end{array}$ & Quantum information processing project \\
\hline Naoki YOKOYAMA & $\begin{array}{r}\text { National Institute of } \\
\text { Advanced Industrial } \\
\text { Science and Technology } \\
\text { (AIST) }\end{array}$ & $\begin{array}{r}\text { National Institute of Advanced } \\
\text { Industrial Science and } \\
\text { Technology (AIST) }\end{array}$ & $\begin{array}{r}\text { Development of Core Technologies for Green } \\
\text { Nanoelectronics }\end{array}$ \\
\hline
\end{tabular}




\section{Annex D. ImPACT Projects}

1. Realizing Ultra-Thin and Flexible Tough Polymers

2. Cell Search Engine - Turning Serendipity into Planned Happenstance -

3. Ubiquitous Power Laser for Achieving a Safe, Secure and Longevity Society

4. Achieving Ultimate Green IT Devices with Long Usage Time without Charging

5. Innovative Cybernic System for a "ZERO Intensive Nursing-care Society"

6. Super High-Function Structural Proteins to Transform the Basic Materials Industry

7. Tough Robotics Challenge (TRC)

8. Reduction and Resource Recycling of High-level Radioactive Wastes through Nuclear Transmutation

9. Ultra-high Speed Multiplexed Sensing System Beyond Evolution for the Detection of Extremely Small Quantities of Substances

10. Innovative Visualization Technology to Lead to Creation of a New Growth Industry

11. Actualize Energetic Life by Creating Brain Information industries

12. Advanced Information Society Infrastructure Linking Quantum Artificial Brains in Quantum Network

13. Small Synthetic Aperture Radar Satellite System for On-Demand Observation

14. Artificial Cell Reactor Technology for an Enriched and Secure Society and New Bioengineering

15. Bionic Humanoids Propelling New Industrial Revolution

16. An Ultra Big Data Platform for Reducing Social Risks 


\section{Annex E. Moonshot goals and targets}

\begin{tabular}{|c|c|}
\hline Moonshot goal & Targets \\
\hline $\begin{array}{l}\text { Realisation of a society } \\
\text { in which human beings } \\
\text { can be free from } \\
\text { limitations of body, } \\
\text { brain, space, and time } \\
\text { by } 2050 \text {; }\end{array}$ & $\begin{array}{l}\text { Cybernetic avatar infrastructure for diversity and inclusion } \\
\text { - Development of technologies and infrastructure to carry out large-scale complex tasks combining large numbers of } \\
\text { robots and avatars teleoperated by multiple persons by } 2050 \text {. } \\
\text { - Development of technologies and infrastructure that allow one person to operate more than } 10 \text { avatars for one task at } \\
\text { the same speed and accuracy as one avatar by } 2030 \text {. } \\
\text { Cybernetic avatar life } \\
\text { - Development of technologies that will allow anyone willing to augment their physical, cognitive, and perceptional } \\
\text { capabilities to the top level, and spread of a new lifestyle that will be welcomed by society, by } 2050 \text {. } \\
\text { - Development of technologies that will allow anyone willing to augment their physical, cognitive, and perceptional } \\
\text { capabilities for specific tasks, and proposal of a new lifestyle that will be welcomed by society, by } 2030 \text {. }\end{array}$ \\
\hline $\begin{array}{l}\text { Realisation of ultra- } \\
\text { early disease prediction } \\
\text { and intervention by } \\
2050 \text {; }\end{array}$ & $\begin{array}{l}\text { - Establishment of a system for disease prediction and evaluation of pre-symptomatic states in order to suppress and } \\
\text { prevent disease onset, through integrated analysis of the entire functional network between human organs, by } 2050 . \\
\text { - Establishment of a strategy that enables the conversion of a pre-symptomatic state to a healthy state, by clarification } \\
\text { of functional changes in human physiology along life course considering the comprehensive network between organs, } \\
\text { by } 2050 \text {. } \\
\text { - Identification of disease-related network structures and establishment of innovative prediction and intervention } \\
\text { methods by } 2050 \text {. } \\
\text { - Understanding of the comprehensive network between human organs by } 2030\end{array}$ \\
\hline $\begin{array}{l}\text { Realisation of Al robots } \\
\text { that autonomously } \\
\text { learn, adapt to their } \\
\text { environment, evolve in } \\
\text { intelligence and act } \\
\text { alongside human } \\
\text { beings, by 2050; }\end{array}$ & $\begin{array}{l}\text { - Development of Al robots that humans feel comfortable with, have physical abilities equivalent to or greater than } \\
\text { humans, and grow in harmony with human life, by } 2050 \text {. } \\
\text { - Development of Al robots that behave well with humans under certain conditions, and allow over } 90 \% \text { of people to feel } \\
\text { comfortable with them, by } 2030 \text {. } \\
\text { - Development of an automated Al robot system that aims to discover impactful scientific principles and solutions, by } \\
\text { thinking and acting in the field of natural science, by } 2050 \text {. } \\
\text { - Development of an automated Al robot system that aims to support the process of discovery for scientific principles } \\
\text { and solutions to specific problems by } 2030 \text {. } \\
\text { - Development of Al robots that autonomously make judgements and act in environments where it is difficult for humans } \\
\text { to act by } 2050 \text {. } \\
\text { - Development of Al robots that operate unattended under human supervision in specific circumstances by } 2030 \text {. }\end{array}$ \\
\hline $\begin{array}{l}\text { Realisation of } \\
\text { sustainable resource } \\
\text { circulation to recover } \\
\text { the global environment } \\
\text { by 2050; }\end{array}$ & $\begin{array}{l}\text { Cool Earth and Clean Earth } \\
\text { - Global deployment of commercial plants or products utilizing circulation technology by } 2050 . \\
\text { Cool Earth } \\
\text { - Development of circulation technology on a pilot scale for reducing greenhouse gases that is also effective in terms of } \\
\text { life cycle assessment (LCA) by } 2030 \text {. } \\
\text { Clean Earth } \\
\text { - Development of technology on a pilot scale or in a form of prototype that converts environmentally harmful substances } \\
\text { into valuable or harmless materials by } 2030 \text {. }\end{array}$ \\
\hline $\begin{array}{l}\text { Creation of the industry } \\
\text { that enables } \\
\text { sustainable global food } \\
\text { supply by exploiting } \\
\text { unused biological } \\
\text { resources by 2050; }\end{array}$ & $\begin{array}{l}\text { - Technical development of the circular food production systems by biological measures, e.g. utilizing microbes and } \\
\text { insects, by } 2050 \text {. } \\
\text { - Development of the technical solutions for eliminating food loss and waste and for achieving both healthy life and } \\
\text { sustainable food consumption by } 2050 \text {. } \\
\text { - Evaluation of the technical achievements and discussion on the ethical, legal and social implications (ELSI) matters } \\
\text { will be done by 2030, for global spread of the technology by } 2050\end{array}$ \\
\hline $\begin{array}{l}\text { Realisation of a fault- } \\
\text { tolerant universal } \\
\text { quantum computer that } \\
\text { will revolutionize } \\
\text { economy, industry, and } \\
\text { security by } 2050 \text {. }\end{array}$ & $\begin{array}{l}\text { - Achievement of the large-scale integration required for fault-tolerant universal quantum computers by around } 2050 . \\
\text { - Development of a certain scale of NISQ computer and demonstration of the effectiveness of quantum error correction } \\
\text { by } 2030\end{array}$ \\
\hline $\begin{array}{l}\text { Realisation of } \\
\text { sustainable medical } \\
\text { and nursing care } \\
\text { systems to prevent and } \\
\text { overcome major } \\
\text { diseases by } 2040, \text { for } \\
\text { everyone to enjoy life } \\
\text { without health anxiety }\end{array}$ & $\begin{array}{l}\text { Realisation of a society where everyone can prevent diseases spontaneously in daily life } \\
\text { - Establish infrastructure to maintain good health physically and mentally by developing technologies, in order to keep } \\
\text { good health and prevent the onset and aggravation of diseases by control of immune systems or sleep, etc.; to } \\
\text { visualize individual physical and mental state in daily life and to urge people to voluntarily take healthy maintenance } \\
\text { actions most suitable for them by } 2040 \text {. } \\
\text { - Develop technologies to monitor all living body trends with lower physical and mental load by } 2030 . \\
\text { Realisation of a medical network accessible for anyone from anywhere in the world } \\
\text { - Establish a medical network to provide the same level of medical care as a normal time regardless of region and even }\end{array}$ \\
\hline
\end{tabular}




\begin{tabular}{|l|l|}
\hline until 100 years old & $\begin{array}{l}\text { upon disasters and emergencies by developing diagnostic and treatment devices for simple tests and treatments at } \\
\text { home, etc. and diagnosis- and treatment-free technologies for part of chronic diseases by 2040. In addition, develop } \\
\text { methods for radical treatment and earlier intervention for diseases such as cancer and dementia by substantially } \\
\text { reducing the development period of drugs and medical devices, etc. through establishment of data science and } \\
\text { evaluation systems by 2040. }\end{array}$ \\
& -Establish a technology platform to provide quality medical and nursing care suitable for each individual appropriately \\
even with less providers by developing compact, speedy and high-sensitivity diagnostic and treatment devices as well & as technologies to further enhance doctors' medical opinion and diagnostic capability by 2030 \\
& Realization of drastic improvement of QoL without feeling load (realization of an inclusive society without health \\
disparity) & - Establish a social infrastructure to enable self-reliant life at home without depending on nursing care by developing \\
such technologies as the recovery of body function with rehabilitation without feeling load, normalization of ailing \\
biocontrol systems, regeneration or substitution of weakened organs and so forth by 2040. \\
- Develop technologies to improve body function through load-reducing 2 rehabilitation and support self-reliant life at \\
home and to improve ailing living biocontrol systems by 2030
\end{tabular}




\section{Annex F. Challenges and opportunities of the SIP and ImPACT programmes}

\begin{tabular}{|c|c|c|}
\hline & Challenges & Opportunities \\
\hline SIP & $\begin{array}{l}\text { - High transaction costs. Several meeting including } \\
\text { Governing Board, Promotion Committees, working } \\
\text { groups, etc. with many people. } \\
\text { - Insufficient administrative support and financial } \\
\text { treatment of Programme Directors with regards to } \\
\text { their wide array of responsibilities of the Programme } \\
\text { Directors. } \\
\text { - Turnover of Cabinet Office agents every } 2 \text { or } 3 \text { years. } \\
\text { This rule makes it hard to maintain the consistency of } \\
\text { the program its } 5 \text { years term and allow policy } \\
\text { learning. } \\
\text { - Some SIP programmes were considered too science- } \\
\text { based - SIP should focus only on areas where } 1) \\
\text { demonstration would be feasible within the term of } \\
\text { the programme 2) there is a clear need for inter- } \\
\text { ministerial coordination, linking research, innovation } \\
\text { and sectoral authorities. } \\
\text { - Insufficient financial contribution by industry. } \\
\text { - Regulatory reforms - The necessary regulatory } \\
\text { reforms in each program should be assessed and } \\
\text { negotiated at high level, in CSTI, Cabinet Office and } \\
\text { relevant ministries. } \\
\text { - Not enough attention to exit strategies by Programme } \\
\text { Directors }\end{array}$ & $\begin{array}{l}\text { - Improved cross-ministerial coordination under the leadership of } \\
\text { CSTI and the Cabinet Office. } \\
\text { - Leadership of PDs: the strong leadership of the Programme } \\
\text { Directors has been identified a key success factor. PDs decide } \\
\text { upon the R\&D Plan of their SIP programme and allocate the } \\
\text { funds, based on the results of the annual programme evaluation. } \\
\text { They are also deem essential to help cross-ministerial } \\
\text { coordination in the Promotion Committee. } \\
\text { - The active involvement of CSTI made possible a continuous } \\
\text { policy approach from basic research to demonstration and good } \\
\text { cooperation between research and industry. } \\
\text { - Policy learning in implementation agencies. The involvement of } \\
\text { agencies as implementation organisations of the SIP program } \\
\text { has induced some changes in the practices and culture of } \\
\text { programme management. They tend to become more result } \\
\text { oriented and more flexibility } \\
\text { - Flexibility in SIP individual programmes has been facilitated by } 1 / \\
\text { the fact that each programme has its own structure of } \\
\text { governance (while still complying with the basic SIP policy and } \\
\text { implementation principle designed by the CSTI) } 2 / \text { the decision } \\
\text { making power of each Programme Director. }\end{array}$ \\
\hline ImPACT & $\begin{array}{l}\text { - The directionality of the programmes tended to limit } \\
\text { the 'out of the box' thinking of core researchers } \\
\text { - Too much emphasis on innovation, to the detriment } \\
\text { of the high risk - high reward aspect } \\
\text { - Focused on science and technology, while } \\
\text { addressing societal problems also require regulatory } \\
\text { reforms or system changes } \\
\text { - Lack of participation by foreign researchers and } \\
\text { international collaborations } \\
\text { - No explicit criteria for "risk-taking," and "accepting } \\
\text { failure." (depended on evaluators judgement). } \\
\text { - Not clear whether culture of "risk-taking" was shared } \\
\text { with participants and stakeholders. } \\
\text { - Need for logic model/roadmap for success and stage- } \\
\text { - gate management } \\
\text { - Limited mobility: after the end of program, most PMs } \\
\text { came back to universities and companies to which } \\
\text { they belonged } \\
\text { - Need for seamless support for technology transition } \\
\text { - Traditional external evaluation may not work well } \\
\text { (evaluators may not understand the aims of the } \\
\text { program and focus on technology only.) }\end{array}$ & $\begin{array}{l}\text { - The program has realised cutting-edge and innovative research. } \\
\text { - Many programs were expected to continue successfully after the } \\
\text { program. (including the establishment of } 15 \text { startups) } \\
\text { - Flexibility of program management and budget. } \\
\text { - Program designing phase after the nomination of PMs was useful } \\
\text { in developing more effective program. }\end{array}$ \\
\hline
\end{tabular}

Note: The challenge and opportunities of the SIP result from the author's own assessment and the SIP evaluation. Regarding ImPACT, the main sources are Arimoto and Oyamada (2020) and CSTI (2019). 


\section{Endnotes}

\footnotetext{
${ }^{1}$ The acronym OECD-CSTP is used for this committee in order to avoid any confusion with the Japan Council for Science and Technology Policy. The acronym 'CSTP' is only used for this institution.
}

${ }^{2}$ Four primary priorities: (1) Life sciences; (2) Information and Communication Technologies ; (3) Environmental sciences ; (4) Nanotechnology and materials;

Four secondary priorities: (5) Energy; (6) Manufacturing technology; (7) Infrastructure; (8) Frontier (i.e. outer space and the ocean). See CSTP (2001), Promotion Strategy for 8 Prioritized Areas, https://www8.cao.go.jp/cstp/english/basic/2nd-strategy_01-05.pdf

${ }^{3}$ For instance, life science is supposed to contribute to resolve food shortages and prevent or treat disease in Japan's aging and low-birth-rate society. The targets are even more precise since all fields are divided into subcategories.

4 The 13 'issue-oriented' priorities belongs to three categories: Sustainable growth and selfsustaining regional development: 1) Ensuring stable energy and improving energy efficiency; 2) Ensuring stable resources and cyclical use; 3) Securing a stable food supply; 4) Establishment of a society in which people enjoy long and healthy lives with world-leading medical technology; 5) Building infrastructure for sustainable cities and regions; 6) Extending service life for efficient, effective infrastructure; 7) Improving competitiveness in manufacturing and value creation. Ensure safety and security for our nation and its citizens and a high-quality, prosperous way of life: 8) Addressing natural disasters; 9) Ensuring food safety, living environments, and occupational health; 10) Ensuring Cybersecurity; 11) Addressing national security issues. Addressing global challenges and contributing to global development: 12) Addressing global climate change; 13) Responding to biodiversity loss.

${ }^{5}$ The Council for Science and Technology is an advisory body of MEXT. This body has established since 2004 to advise MEXT during the development and review of basic plans.

${ }^{6}$ See https://www8.cao.go.jp/cstp/sogosenryaku/2015.html. Not translated

${ }^{7}$ Optimization of Energy Value Chain, Developing the Global Environment Information Platform, Realizing the Efficient and Effective Maintenance, Upgrading, and Management of Infrastructure, Realizing a Resilient Society in the Face of Natural Disaster, Intelligent Transport Systems (ITS), New Manufacturing (monozukuri) Systems, Integrated Material Development Systems, Systems for Community Living to Foster a Health-Oriented Nation, Hospitality (omotenashi) Systems, Smart Food Chain Systems, Smart Food Production Systems

${ }^{8}$ AI-related technologies, Cybersecurity technologies, Device technologies, Network technologies, Edge computing, Robotics, Sensor technologies, Actuator technologies, Biotechnology, Biotechnology.

${ }^{9}$ MEXT was created in 2001 from the merger of the Science and Technology Agency (STA) and the former Ministry of Education (Monbusho).

${ }^{10}$ Each annual Comprehensive Strategy includes a chapter dedicated to reaffirm the role of the Council as STI Headquarter.

${ }^{11}$ https://www.meti.go.jp/english/press/2020/1225 001.html. 
${ }^{12}$ These two countries are presented here as benchmarks since they have been, like Japan, subject to a case study.

${ }^{13}$ CRDS was established in 2003 within the Japan Science and Technology Agency (JST). NISTEP was established back in 1988 as part of the Science and Technology Agency (STA), now merged into MEXT. TSC was established in 2014 as part of NEDO.

${ }^{14} 10 \%$ increase of the number of university teachers under 40 ; New hiring rate of female researchers: $30 \%$ (natural sciences), $\quad 20 \% \quad$ (science), $15 \%$ (engineering), $30 \%$ (agricultural), $30 \%$ (medical/dentistry/pharmacy combined); $10 \%$ of papers in Top $10 \%$ cited papers; $20 \%$ increase in transfer of researchers between sectors of companies, universities and public research institutes, transfer from universities to companies and public research institutes: 50\% increase of the amount of joint research from companies at universities and national R\&D corporations; $100 \%$ increase in the number of new listings of R\&D venture companies; $15 \%$ of patent applications filed by SMEs; $50 \%$ increase in the licensing of patent right by university (Cabinet Office, 2019).

${ }^{15}$ There are currently about 45 Headquarters (see https://www.cas.go.jp/jp/seisaku/index.html). A Sustainable Development Goals (SDGs) Promotion Headquarters was established in 2016, headed by the Prime Minister and composed of all Ministers.

${ }^{16}$ For instance, The IT Strategy Headquarters' Deputy Chiefs are the Chief Cabinet Secretary, the Minister in charge of IT, the Minister of Posts and Telecommunications, and the Minister of Economy Trade and Industry. The Members are: Minister of Justice, Minister for Foreign Affairs, Minister of Finance, Minister of Education, Minister of Health and Welfare, Minister of Agriculture, Forestry and Fisheries, Minister of Transport, Minister of Labour, Minister of Construction, Minister of Home Affairs, Chair of the National Public Safety Commission, Chair of the Financial Reconstruction Commission, Director-General of the Management and Coordination Agency, Director-General of the Hokkaido Development Agency, Director-General of the Defense Agency, Director-General of the Economic Planning Agency, Director-General of the Science and Technology Agency, Director-General of the Environment Agency, Director-General of the Okinawa Development Agency, Director-General of the National Land Agency.

See https://japan.kantei.go.jp/it/council/establishment_it.html.

${ }^{17}$ Ministers of State for Specific Missions are ministers positioned in the Cabinet Office. For instance the Minister for State for .Science and Technology Policy is an CSTI executive member. The Minister of State for Intellectual Property Strategy chairs the IP HQ.

${ }^{18}$ https://www.kantei.go.jp/jp/singi/tougou-innovation/dai1/sankou1.pdf

${ }^{19}$ There were expert meetings on AI, safety, biotechnology and quantum technology. See https://www.kantei.go.jp/jp/singi/tougou-innovation/index.html

${ }^{20}$ At individual project or researcher level, the Cross-Ministerial Research and Development Management System (e-Rad) is an online platform that allows since 2008 to check that the same research projects are not funded several times through different schemes. See https://www.erad.go.jp/en/.

${ }^{21}$ Since 2018, CSTI's reformed method for accounting for STI investments by individual ministries follows the accounting standards of the OECD.

${ }^{22} 0.5 \%$ in 2018 according to OECD data.

${ }^{23}$ Another programme named ImPACT implemented between 2013 and 2018 aimed specifically to encourage disruptive innovation.

${ }^{24}$ Clean and efficient energy system; Healthy aging society as a world leading nation; Cutting-edge next generation infrastructure; Resurgence of local region using regional resources and its potential; Reconstruction from the Great East Japan Earthquake in 2011.

${ }^{25}$ The Society of Automotive Engineers (SAE) defines 6 levels of driving automation ranging from 0 (fully manual) to 5 (fully autonomous).

${ }^{26}$ All SIP programme R\&D plans are available at on the CSTI webpage: 
https://www8.cao.go.jp/cstp/english/index.html.

${ }^{27}$ Funds originate from MEXT (Yen 80 billion) and METI (Yen 20 billion). The whole programme is meant to last longer than 5 years.

${ }^{28}$ The call was for not only challenging ideas for research and development, especially those that can help resolve social agenda but also for social agenda that need to be resolved. See the invitation on the Cabinet Office website (https://www8.cao.go.jp/cstp/english/moonshot/ref3.pdf).

${ }^{29}$ MEXT, MHLW, MAFF, and METI (and their respective agencies) will be the main ministries involved in the Programme.

${ }^{30}$ JST (goals 1, 2, 3 and 6 in the list above), NEDO (goal 4), the Bio-oriented Technology Research Advancement Institution / National Agriculture and Food Research Organization (BRAIN/NARO goal 5) and the Japan Agency for Medical Research and Development (AMED - goal 7).

${ }^{31}$ Details on these schemes are available in Larrue (2021) and on the MOIP Online Toolkit. 